Florida International University FIU Digital Commons

$11-5-2014$

\title{
CEO Humility: Development of an Unobtrusive Measure and Strategic Implications
}

Marie-Michele Beauchesne

Florida International University, mbeau001@fiu.edu

DOI: $10.25148 /$ etd.FI14110729

Follow this and additional works at: https://digitalcommons.fiu.edu/etd

Part of the Business Commons

\section{Recommended Citation}

Beauchesne, Marie-Michele, "CEO Humility: Development of an Unobtrusive Measure and Strategic Implications" (2014). FIU

Electronic Theses and Dissertations. 1617.

https://digitalcommons.fiu.edu/etd/1617

This work is brought to you for free and open access by the University Graduate School at FIU Digital Commons. It has been accepted for inclusion in FIU Electronic Theses and Dissertations by an authorized administrator of FIU Digital Commons. For more information, please contact dcc@fiu.edu. 


\section{FLORIDA INTERNATIONAL UNIVERSITY}

Miami, Florida

CEO HUMILITY: DEVELOPMENT OF AN UNOBTRUSIVE MEASURE AND STRATEGIC IMPLICATIONS

A dissertation submitted in partial fulfillment of the requirements for the degree of DOCTOR OF PHILOSOPHY in BUSINESS ADMINISTRATION by

Marie-Michèle Beauchesne 
To: Dean David Klock

College of Business Administration

This dissertation, written by Marie-Michèle Beauchesne, and entitled CEO Humility:

Development of an Unobtrusive Measure and Strategic Implications, having been approved in respect to style and intellectual content, is referred to you for judgment.

We have read this dissertation and recommend that it be approved.

$\begin{array}{r}\text { Karl Kroeck } \\ \hline \text { Hock-Peng Sin } \\ \hline \text { Chockalingam Viswesvaran } \\ \hline \text { Nathan Hiller, Major Professor }\end{array}$

Date of Defense: November 5, 2014

The dissertation of Marie-Michèle Beauchesne is approved.

$\begin{array}{r}\begin{array}{r}\text { Dean David Klock } \\ \text { College of Business Administration }\end{array} \\ \hline \begin{array}{r}\text { Dean Lakshmi N. Reddi } \\ \text { University Graduate School }\end{array}\end{array}$

Florida International University, 2014 
(C) Copyright 2014 by Marie-Michèle Beauchesne

All rights reserved. 


\section{DEDICATION}

I dedicate this dissertation to my parents and brothers. Their unconditional support, encouragement, numerous trips to Miami, and selfless love have made this

journey possible. I am extremely grateful I get to share this special moment in my life with you all.

Love,

Marie 


\section{ACKNOWLEDGMENTS}

I want to thank the members of my committee for their support, words of encouragement, and insights. This dissertation would not have been possible without the support and feedback from my dissertation chair, Nathan Hiller. I am very grateful for his guidance, commitment, and above all the friendship we have developed. His mentorship has greatly impacted both my research skills and teaching style. He has done an amazing job at balancing high expectations for my work while always being understanding and supportive of my career choices. Thank you for your time and dedication and I am looking forward to working with you on more projects in the future.

I also would like to thank all the professors of the management department and everyone at the Center for Leadership for their support and guidance. A special thanks to my dear friend Vivian Cepero who has helped me tremendously throughout this journey.

Lastly, I would like to acknowledge the financial support received from the FIU graduate school and the FIU Center for Leadership. 


\title{
ABSTRACT OF THE DISSERTATION \\ CEO HUMILITY: DEVELOPMENT OF AN UNOBSTRUSIVE MEASURE AND STRATEGIC IMPLICATIONS
}

\author{
by \\ Marie-Michèle Beauchesne \\ Florida International University, 2014 \\ Miami, FL \\ Professor Nathan Hiller, Major Professor
}

Over the past 30 years, the Upper Echelons perspective of strategic management has sought to explain a given organization's strategies and effectiveness as a reflection of the differences in personality, background, and other characteristics of the senior executives that guides each organization. An important stream of research within this field has linked a firm's strategy to the grandiose way that executives are often thought to view themselves - namely through examining the narcissism, core self-evaluations (CSE), and hubris of Chief Executive Officers (CEOs).

In this dissertation, I focus on understanding the strategic impact of CEO humility - a trait that has often been erroneously thought of to represent a poor view of oneself. Consistent with ancient writings and recent research, humility is defined herein as a multi-faceted trait that is the common core of four dimensions: self-awareness, developmental orientation/teachability, appreciation of others' strengths and contributions, and low self-focus.

In the first essay, I explore the conceptual relevance and various potential implications of executive humility. Drawing on existing empirical research about the 
humility construct and general behavioral implications of humility, I argue that executive humility is a critical avenue toward a more rich and nuanced understanding of the delicate interplay and implications of executive self-concept.

In essay two, I develop and validate an unobtrusive measure of CEO humility. Ten indicators of humility are suggested and then validated using a self-reported survey administered to a sample of 30 U.S. and Canadian CEOs. Two behaviors were found to be significantly positively related to self-reported humility: CEOs who volunteered some of their time for non-profit organizations and CEO's who reported that part of their own firm's success was due to the help of the board of directors.

In essay three, I examine the relationship between the level of CEO humility and four firm-level outcomes. Employing a sample of 163 CEOs appointed to S\&P 500 firms between 2005-2008, I show that firms led by humble CEOs (measured by the unobtrusive indicators) tend to outperform others in regards to corporate social performance, while at the same time showing that their financial performance is generally no better or worse. 


\section{TABLE OF CONTENTS}

\section{CHAPTER}

I. Leader Humility in the Executive Context ........................................................... 1

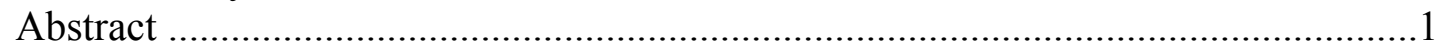

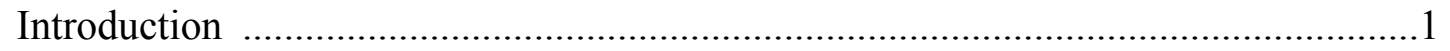

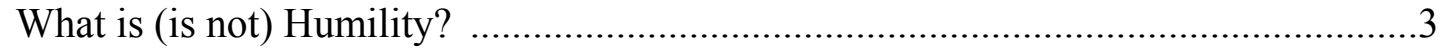

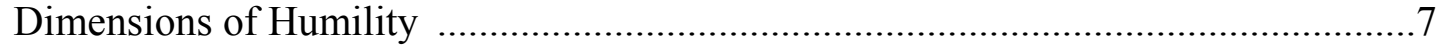

Humility Nomological Network ....................................................................... 11

Correlates of Humility ........................................................................................ 15

Humility in the Context of Upper Echelons Research ........................................20

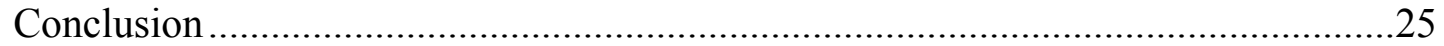

II. Development and Validation of an Unobtrusive Measure of CEO Humility ..............27

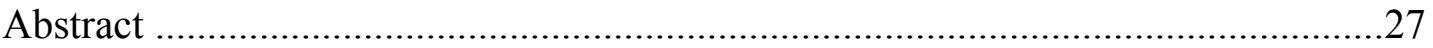

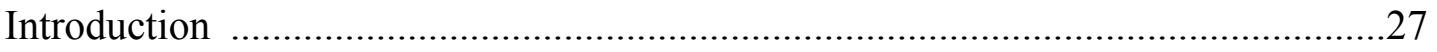

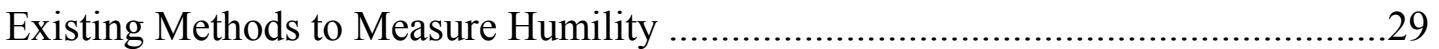

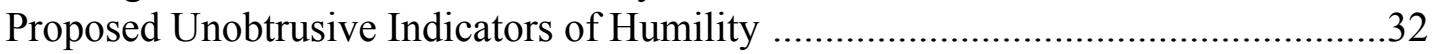

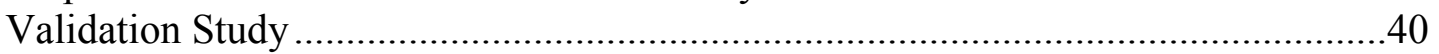

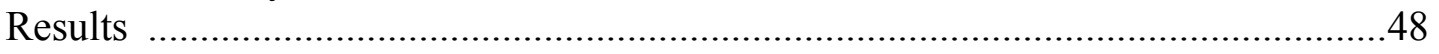

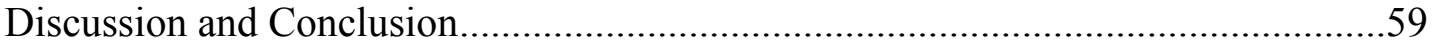

III. Strategic Implications of CEO Humility …......................................................64

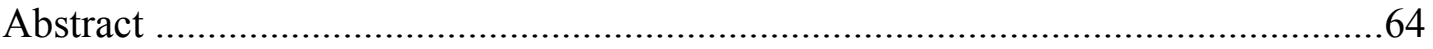

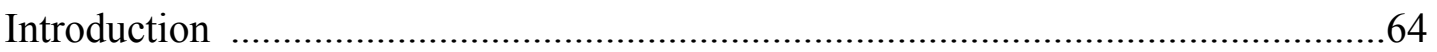

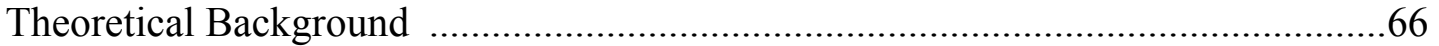

CEO Humility and Corporate Social Performance ...............................................67

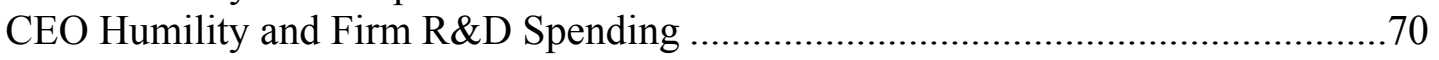

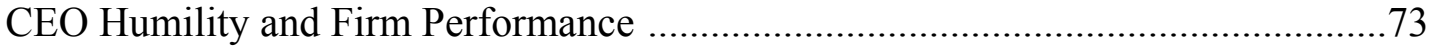

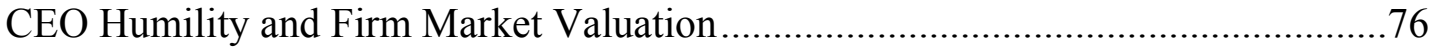

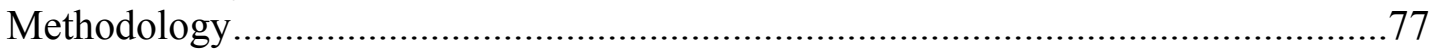

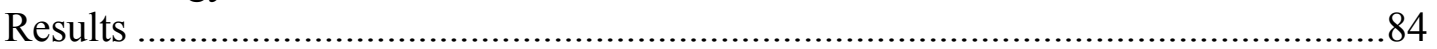

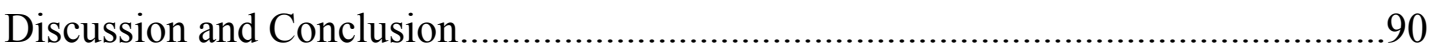

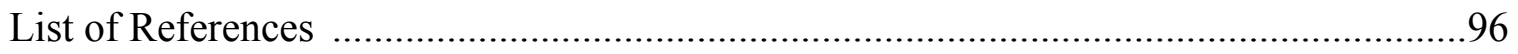

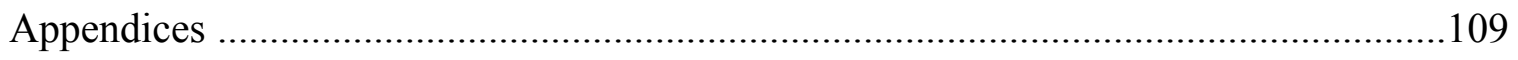

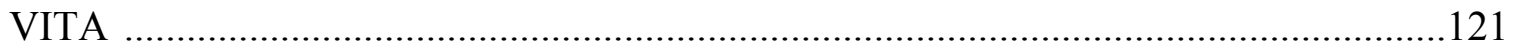




\section{LIST OF TABLES}

TABLE

PAGE

1. Validation Sample Descriptive Statistics \& Reliability Analyses

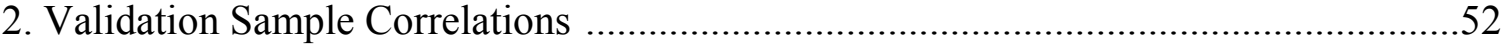

3. Main Study Descriptive Statistics and Correlations ...................................................86

4. Results of GEE Analysis of CEO Humility on Unobtrusive Indicators and CSP ........88

5. Results of GEE Analysis of CEO Humility on Unobtrusive Indicators and R\&D Spending .88

6. Results of GEE Analysis of CEO Humility on Unobtrusive Indicators and ROA

7. Results of GEE Analysis of CEO Humility on Unobtrusive Indicators and Tobin's Q 89

8. Results of GEE Analysis of CEO Humility on Unobtrusive Indicators and DVs .90 


\section{LIST OF FIGURES}

FIGURE

PAGE

1. Qualitative Portrayal of the Conceptual Space Occupied by Humility .........................7

2. Validation Sample - Firm Revenues Distribution .............................................43

3. Validation Sample - Total Number of Employees Distribution .................................44

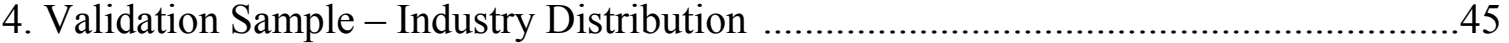

5. Validation Sample Boxplot - Measure of Variability .............................................50

6. Standardized Estimates - Confirmatory Factor Analysis (Humility 4 Dimensions) .....53

7. Standardized Estimates - Confirmatory Factor Analysis (Humility 3 Dimensions) .....54

8. Validation Sample Hierarchical Cluster Analysis ...................................................58

9. Confirmatory Factor Analysis - Unobtrusive Measures ...................................... 81 


\title{
I. Leader Humility in the Executive Context
}

\begin{abstract}
This first study explores the relevance and potential implications of humility in the executive context. Building on leader humility research at the non-executive level (and more general research on the construct of humility), several avenues are proposed to integrate humility as an important self-concept variable to examine at the CEO-level. It is argued that the inclusion of humility in the Upper Echelons literature will broaden the discussion on the strategic implications of executive self-concept beyond the traditional dimensions of narcissism, hubris and CSE to provide a more rich and nuanced understanding of the delicate interplay and implications of executive self-concept.
\end{abstract}

\section{Introduction}

How "should" executives think of themselves? In the last fifteen years, there has been growing research interest in the fields of strategic management and leadership in the constructs and implications of executive self-concept spurred in part by corporate scandals, malfeasance, and tales of executive excess. This research has focused largely on what might be considered the "high" end of self-concept personality dimensions narcissism, hubris, overconfidence and core self-evaluations (CSE) (e.g., Chatterjee \& Hambrick, 2007, 2011; Hayward \& Hambrick, 1997; Li \& Tang, 2010; Resick, Whitman, Weingarden, \& Hiller, 2009). There is growing evidence that those CEO self-concept 
personality traits are predictive of a host of firm-level outcomes such as strategic dynamism (Chatterjee \& Hambrick, 2007), different measures of team performance (Resick et al., 2009), and premiums paid for acquisitions (Hayward \& Hambrick, 1997). Notwithstanding the value of studying CEOs who think extremely highly of themselves, I argue here that focusing exclusively on those "high" end self-concept personality dimensions may give us an incomplete picture of the strategic implications of CEO selfview.

In order to get a more refined understanding of the impact that CEO self-view has on organizational outcomes, I suggest the study of CEO humility as an important path forward. The study of humility and its interplay with leadership is gaining momentum in both the fields of management and psychology (Ou et al., 2014; Owens, Johnson, \& Mitchell, 2013). Historically considered to be an important virtue by theologists and philosophers (Morris, Brotheridge, \& Urbanski, 2005), humility has recently been suggested to be an important pillar of several positive theories of leadership such as servant leadership, ethical leadership, spiritual leadership and authentic leadership (e.g., Avolio, Walumbwa, \& Weber, 2009; Barbuto \& Wheeler, 2006; Brown \& Trevino, 2006; van Dierendonck \&Nuijten, 2011). These theories all emphasize the importance of having leaders who display humility, self-awareness and integrity. Humility, in addition to the growing interest in the field of leadership, has also become a prominent topic in personality studies. The work of Lee and Ashton $(2004,2005,2006,2008)$ that proposes the inclusion of humility as the sixth dimension of the Big 5 (i.e., honesty-humility dimension) has gained growing acceptance among personality researchers. 
Despite the growing evidence of the relevance of the construct of humility as a gateway to understanding individual work performance, social relationships, and importantly, leadership, very few studies have examined humility in the field of strategic management. Jim Collins, in his best-seller Good to Great (2001), popularized the idea that not all successful CEOs are highly visible, extraverted individuals, and showed that some of the most successful organizations were in fact led by humble CEOs with strong professional will. He brought attention to the idea that effective leadership is not all about grandiosity and self-confidence, and that humility is an important piece of that puzzle. Notwithstanding the methodological issues for which this book has been criticized, Collins work has sparked interest in studying humility as an important characteristic for CEOs to possess. More recently, Ou and colleagues (2014) have studied CEO humility (using a Chinese sample) linking it to several top management team (TMT) processes (e.g., TMT integration) and employee-level outcomes (e.g., middle managers' work engagement, affective commitment, and job performance). While CEO humility has been found to be related to positive employee-level outcomes, we have yet to uncover the strategic implications they have on the firms they lead.

In this first essay, I 1) define humility 2) discuss how it differs from other traits in its nomological network 3) examine the correlates of humility 4) discuss how humility is important to broaden our understanding of the strategic implications of CEOs views of self, and 5) offer two avenues for future research on CEO humility which will be further examined in essays two and three. 


\section{What is (not) humility?}

Historically, the topic of humility has been studied extensively in both theology and philosophy. Since humility often involves an appreciation of knowledge and guidance beyond the self, it is an important virtue in several religions including Buddhism, Christianity, Hinduism, etc. (Owens, 2009). In philosophy, humility is characterized as a temperance virtue - a virtue that guards against excess (Park \& Peterson, 2003). Considering the abundant work on humility pertaining to the philosophical, theological, and psychological perspectives, there has yet to be an agreed upon set of dimensions although many differing conceptualizations have emerged over time (Ou, 2011; Owens, 2009).

Definitions of humility usually fall into two broad categories: humility as a sign of an individual perceiving oneself to have little worth, or, humility as being centrally about a fair self-evaluation (neither too positive nor too negative) and associated with adaptiveness, growth, and prosocial patterns (Owens, 2009). Early writings and colloquial definitions of humility have mainly fallen into the first category, contributing to a pervasive misconception that humility is, in essence, a weakness - summed up by the phrase "I am not worth it" (Weiss \& Knight, 1980). While lay definitions of humility often include low self-regard and unworthiness, Tangney's (2001) review of literature on humility demonstrated that most of the work published in theology, philosophy, and psychology has portrayed humility as a positive characteristic and humble individuals are described as having a stable sense of self-worth and self-respect (Owens, Rowatt, \& Wilkins, 2011; Vera \& Rodriguez-Lopez, 2004). 
Using this virtuous conceptualization, scholars have proposed anywhere from three to thirteen dimensions of the broad construct of humility (Vera and RodriguezLopez, 2004; Owens et al., 2013). Owens and colleagues (2013) argued that the differing definitions of humility stand partly from the fact that some have a more intrapersonal and internal focus (e.g., balanced processing of personal strengths and weaknesses), whereas others capture the manifested, external, expressed dimensions of humility (e.g., seek to learn from others and listen to advice). In addition, while some scholars have operationalized humility as a trait (e.g., Hackett \& Wang, 2012; Morris et al. 2005; Ou et al. 2014), several leadership approaches (e.g., servant leadership, authentic leadership, spiritual leadership) tend to treat it as a leadership component undifferentiated from leader behaviors. In this essay, I focus on the psychological perspective that suggests humility is a personal trait distinct from leadership behaviors. Whereas a systemic review of all previous definitions of humility is beyond the scope of this section, I review herein some of the most widely cited humility definitions, emphasizing both their similarities and differences.

Lee and Ashton's work $(2004,2005,2006,2008)$ on the extension of the Big 5 Personality framework to include the dimension of honesty-humility has greatly contributed to the study of humility. The added dimension is argued to comprise four facets: sincerity, fairness, greed avoidance and modesty. Derived from lexical studies of personality structures, the honesty-humility factor was found to be strongly negatively correlated with the Dark Triad personality traits - psychopathy, Machiavellianism, and narcissism (with correlations ranging from -0.53 to -0.72) (Lee \& Ashton, 2005). While there is considerable overlap between the honesty-humility dimension of the HEXACO 
model and recent definitions of humility, in more traditional humility definitions the facets of sincerity and fairness are not usually included.

Another widely cited definition is the one by Tangney (2002) who proposed that the key components of humility are: an accurate self-assessment of abilities and achievements, self-awareness of mistakes and limitations, openness to new ideas, information and advice from others, capacity to keep successes and accomplishments in perspective, low self-focus, and appreciation of others. Owens (2009) performed a systematic review of the previous 10 years of humility literature from psychological and organizational behavior journals which led him to a four-factor structure which encompasses self-awareness, developmental orientation/teachability, appreciation of others' strengths and contributions, and low self-focus. These four constituents are argued to be the core features of humility and be closely interrelated.

More recently, Owens and colleagues (2013) suggested a definition of expressed humility which included three broad categories of behaviors that underlie the construct manifested willingness to view oneself accurately, displayed appreciation of others, and an openness to feedback/teachability. With a focus on the external aspects of humility, the authors proposed that these three dimensions are the main behavioral manifestations of humility. Arguing that humility definitions should include both the cognitive/motivational and behavioral elements of the construct, Ou and colleagues (2014) suggested a structure encompassing six dimensions adding - low self-focus, selftranscendent pursuit, and transcendent self-concept - to Owens and colleagues' threefactor structure. Although the terminology often varies among the different definitions, the suggested dimensions usually overlap considerably. For example, while Ou and 
colleagues (2014) defined a self-transcendent pursuit as its own dimension of humility, it is often included as a sub-facet of low self-focus (Owens, 2009).

While there is still not one definite accepted set of humility dimensions, there is a growing consensus emerging among scholars on a general definition of humility which describes humble individuals as self-aware of their strengths and limitations, open to learn and seek advices from others, appreciative of others' strengths and contributions, and not self-centered. In this essay humility is defined as a multi-faceted trait which is the common core of the four dimensions of humility which appear most often in previous conceptualizations (Owens, 2009): developmental orientation (i.e., teachability), selfawareness, appreciation of others, and low self-focus (see Figure 1).

Figure 1: Qualitative Portrayal of the Conceptual Space Occupied by Humility

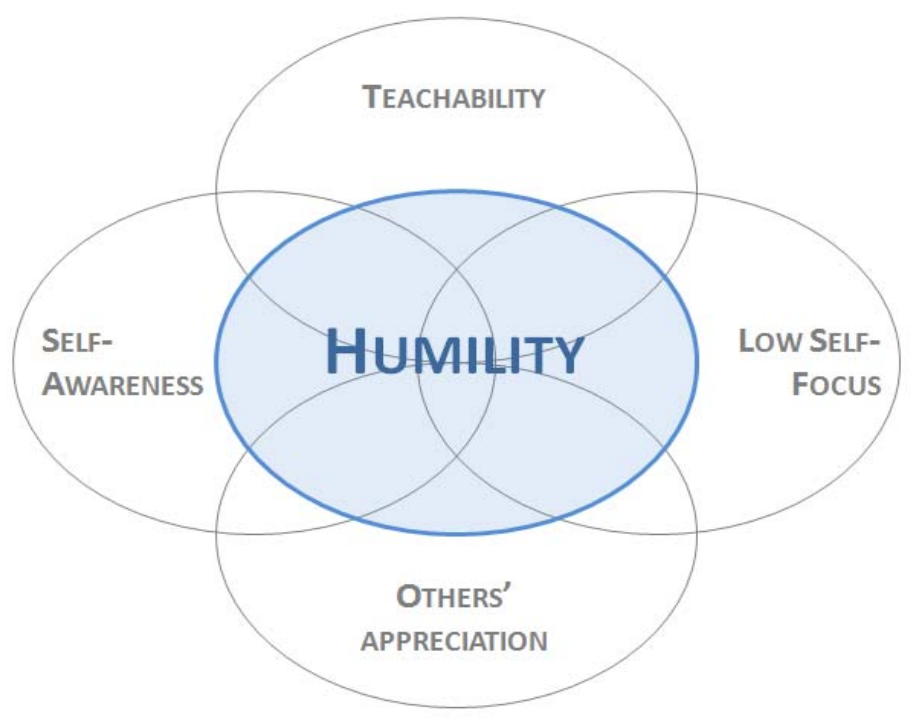

Qualitative Portrayal of the Conceptual Space Occupied by Humility

Dimensions of Humility 


\section{Developmental Orientation/Teachability}

"There is nothing noble in being superior to your fellow man; true nobility is being superior to your former self." - Ernest Hemingway

Humble individuals are characterized as having a developmental orientation. They are receptive to new paradigms and eager to learn from others (Vera \& RodriguezLopez, 2004). They have an open-mind, a willingness to seek advice and a desire to constantly learn (Tangney, 2000). Aware of their weaknesses (captured by the selfawareness dimension of humility), humble individuals seek continual improvement, which translates into an openness to new ideas, feedback, advice, and information (Tangney, 2000). The developmental orientation, which characterizes humble individuals, has critical implications for leadership (Owens, 2009). Alexander and Wilson (1997) argued that having a desire and an openness to learn is one of the most important capacities of effective leaders. Considering the new challenges of the current "knowledge" economy and the ever rapid technological changes, organizations are more than ever in need of leaders who have a capacity to absorb new information, learn from others, and develop new skills (Owens et al., 2013). In addition, leaders who display teachability provide a sense of voice to followers, which has been found to be related to greater trust, motivation, and a sense of justice (Cropanzano et al., 2007).

\section{Self-Awareness}

"I am who I am; no more, no less." - Terry Goodkind

The most commonly cited dimension of humility is self-awareness - the capacity to evaluate your strengths and weaknesses without positive or negative exaggeration 
(Owens, Rowatt, \& Wilkins, 2011). Humble individuals are characterized as having an objective self-view, which entails both the capacity to accurately assess one's abilities and successes and to acknowledge and take accountability for one's mistakes, imperfections and limited knowledge (Exline \& Geyer, 2004; Tangney, 2002). As opposed to low selfesteem, which is associated with having a negative self-view, humility (and its dimension of self-awareness) focuses on an accurate self-view and a non-defensive acknowledgement of strengths and weaknesses (Exline \& Geyer, 2004). The accurate self-view, which characterizes humble leaders, makes them less prone to the overconfidence that has often been associated with poor decision making and selfcomplacency (Owens et al., 2013; Vera \& Rodriguez-Lopez, 2004). A balanced awareness will also help leaders know when to take action versus learn more about an issue, as well as surround themselves with complementary people, when they lack the necessary expertise in a given situation (Owens, 2009). Self-awareness is also a key component of authentic and servant leadership, which have been found to be predictive of a host of positive outcomes such as organizational citizenship behaviors, organizational commitment, satisfaction with supervisor and performance (see Avolio, Walumbwa, \& Weber, 2009 for a review). Practitioners also seem to recognize the importance for leaders to have a balanced self-awareness, which explains the inclusion of personality assessments and other self-awareness exercises, in leadership trainings. 


\section{Appreciation of Others' Strengths and Contributions}

"You need to be aware of what others are doing, applaud their efforts, acknowledge their successes, and encourage them in their pursuits. When we all help one another, everybody wins.” - Jim Stovall

Another facet of humility refers to the capacity to view others in an appreciative, non-threatened way (Exline et al., 2004; Owens, 2009). Humility allows individuals to value the work and contributions of others (Tangney, 2002) without eliciting feelings of inferiority (Owens, 2009). It promotes an "other-enhancing" rather than a "selfenhancing" attitude (Morris et al., 2005). Humility may also enable an individual to transcend the comparative-competitive model of self-evaluation - allowing that person to view others' strengths and talents as opportunities to learn and grow instead of perceiving them as threats (Owens, 2009). In the organizational context, humble leaders are more likely to identify and value followers' unique talents (Owens et al., 2013). This facet of humility has also been linked to the concept of inclusiveness - the extent to which the leader is open to input and shows appreciation for the contributions of other individuals (Nembhard \& Emondson, 2006). Humble leaders openly rely on others (Weick, 2001), treat them as equals (Whitener et al., 1998) and include them in the decision making process (Morris et al., 2005; Owens \& Hekman, 2012). Ou and colleagues (2014) found empirical support for the proposition that humble leaders are more likely to include subordinates in decision making, more specifically they found that humble CEOs engage in more empowering leadership behaviors. 


\section{Low Self-Focus}

“True humility is not thinking less of yourself; it is thinking of yourself less." - C.S. Lewis

CEO humility also encompasses a relatively low self-focus. As opposed to narcissism, which reflects an intoxication and fixation with the self, humility involves "forgetting the self" and recognizing that one is only a small piece of the larger universe (Owens, 2009; Tangney, 2002). As such, humility has been found to be an important virtue that encourages cooperative and prosocial behaviors in organizations (Exline \& Geyer, 2004; Owens, 2009). Humble leaders are seen as being less self-focused and more engaged in self-transcendent pursuits (Ou et al., 2014). They are unlikely to seek undue respect or benefits and do not need, nor want, to be the center of attention (Rowatt et al., 2006). Understanding what leads individuals to transcend their self-interests and engage in extra roles that benefit their organizations has been an important research topic among management scholars (George and Brief, 1992; Podsakoff et al., 1993; Organ and Ryan, 1995), and humility has been argued to be a potential predictor of such prosocial type behaviors in organizations (Exline, Geyer, 2004; Owens, 2009). Thus, this humility dimension appears to have critical implications in the leadership context (particularly at the top executive level) since organizations want leaders who will make decisions for the good of the collective and not for self-interested motives (Owens, 2009).

\section{Humility Nomological Network}

As part of defining and understanding the construct of humility, it is important to place humility within a nomological network of other existing traits related to self-views. Understanding how humility fits into the broader individual's self-view arena is a critical 
task in moving humility research forward. The central question is whether humility occupies the low end of narcissism or hubris constructs? Recent studies have found preliminary evidence that humility is not just the low end of a narcissism, hubris, or CSE construct continuum - it is distinct, both conceptually and empirically, from these other traits (Ou et al., 2014; Owens et al., 2013). I review herein how humility differs from three other self-view traits that have received considerable attention in the Upper Echelons literature namely: narcissism, core self-evaluations, and hubris.

\section{Humility versus Narcissism}

Narcissistic individuals are characterized as having a strong self-focus, a feeling of superiority and entitlement, and a constant need for attention and admiration (Bogart, Benotsch, \& Pavlovic, 2004; Chatterjee \& Hambrick, 2007). When comparing the definition of narcissism with humility, we observe some conceptual overlap between narcissism and the low self-focus dimension of humility. While humble individuals are said to shy away from public attention and would rather not be the center of attention (Rowatt et al., 2006), narcissistic individuals tend to do the opposite. However, as a multifaceted trait, humility is much broader than anti-narcissism (i.e., the low end of narcissism) - humility also captures the dimensions of openness to learn, appreciation of others' strengths, and self-awareness, which are not included in the construct of narcissism $(\mathrm{Ou}, 2011)$. In addition, while humility is associated with a stable self-view, which does not overinflate with praise and success or deflate with criticism and failure, narcissism refers to wide fluctuations from grandiose to negative self-views (Owens et al., 2013). True narcissists are hypersensitive to criticism and have a fragile sense of self (Rosenthal \& Pittinsky, 2006). On the other end, humble individuals are said to have a 
stable sense of self-worth and self-respect (Owens, Rowatt, \& Wilkins, 2011; Vera \& Rodriguez-Lopez, 2004).

From an empirical standpoint, correlations found between narcissism and humility have varied from -.07 (Ou, 2011) to -.63 (Owens et al., 2013). When humility and narcissism were measured via both other-report and self-report surveys, correlations tended to be higher when both constructs were measured using other-reports. For example, Owens (2009) found a correlation of -.16 when both traits were measured with self-reports and -.63 when measured with other-reports. Potentially, close others overemphasize the behavioral manifestations of humility as compared to the more internal components of humility (e.g., self-awareness). In other words, while humility and anti-narcissism appear to be different conceptually, close others may use similar behavioral markers to assess both the humble and narcissistic tendencies of the ratee. In addition, correlations seem to vary depending on the nature of the sample. For example, while $\mathrm{Ou}$ (2011) found a non-significant correlation between narcissism and humility ( $\mathrm{r}=-$ .08 ) when using a sample of MBA students, the correlation between the two same variables was -.24 using a CEO sample. In sum, more empirical work is needed to further examine the interplay between narcissism and humility. While the precise empirical relationship between these constructs is not well understood, it certainly appears that in any case they are not empirically identical. And certainly, from a conceptual standpoint, while there is some overlap, there are also significant differences between narcissism and humility. The observed fluctuations in the correlations found between narcissism and humility appear to be driven, at least partly, by the nature of the sample, the approach to measuring the constructs (i.e., other-reports versus self-reports), and the inclusion, or not, 
of the low self-focus dimension of humility, which overlaps considerably with antinarcissism.

\section{Humility versus Core Self-Evaluations}

Core self-evaluations (CSE) refer to the global assessment one makes about one's own self-worth and capabilities (Chang, Ferris, Johnson, Rosen, \& Tan, 2012; Judge, Locke, Durham, \& Kluger, 1998). Defined as the common core of self-esteem, selfefficacy, internal locus of control and emotional stability, high CSE individuals see themselves as valuable, capable, agentic, and are less prone to anxiety (Hiller \& Beauchesne, 2014). When comparing the construct of humility with core self-evaluations, an important distinction is how humility is associated with having an accurate self-view, as opposed to CSE which suggests an optimistic (i.e., positive) self-view (Owens et al., 2013). While this distinction is crucial, humility and CSE also share some commonalities. For example, by taking personal accountability for mistakes and failures, humble leaders display an internal locus of control, which is a key component of CSE (Ou, 2011). Humble individuals also believe they can learn and improve their personal weaknesses which gives them a sense of control over their destiny (Owens et al., 2013). Similarly, individuals with an internal locus of control believe life is within their control and will not blame chance, fate or outside events (Rotter, 1966).

Empirically, scholars have argued that the two constructs should be weakly positively related (Ou, 2011). Owens and colleagues (2013) found humility and CSE to be unrelated, whereas $\mathrm{Ou}(2011)$ found the two constructs to have a weak positive relationship ( $\mathrm{r}=.16$ for other-report measure and $\mathrm{r}=.25$ for self-report measure). Overall, it 
appears that the two multi-faceted constructs are different both conceptually and empirically.

\section{Humility versus Hubris}

Hubris, another self-view variable that has received considerable attention in the Upper Echelons literature (e.g., Hayward \& Hambrick, 1997; Li \& Tang, 2010), is generally defined as an "exaggerated self-confidence". Unlike narcissism and core selfevaluations, hubris is not a well-validated psychological construct (Hiller \& Hambrick, 2005). Scholars have used different proxies to capture CEO hubris such as the propensity to overpay during corporate takeovers, recent media praise, and the difference between an

objective measure of performance and the CEOs subjective measure of performance (e.g., Hayward \& Hambrick, 1997; Li \& Tang, 2010). The use of such varied and nonvalidated proxies makes it difficult to compare hubris to other traits.

Hubris is said to refer to an exaggerated belief, which diverges from objective standards, about one's own judgement (Hayward \& Hambrick,1997; Hiller \& Hambrick, 2005; Li \& Tang, 2010). Conversely, humble individuals are characterized as having an accurate self-view and demonstrating a willingness to learn and listen to others' advice (Morris et al., 2005). Thus, when making decisions they will value the opinions of others and will not exclusively rely on their own judgment (Ou et al., 2014). While it has never been empirically tested, I would expect a weak negative relationship between hubris and humility based on the conceptual differences described above.

In sum, it appears that humility is a distinct construct from other traits in its nomological network. While narcissism may be negatively related to the low self-focus 
dimension of humility and an internal locus of control may be captured by both CSE and humility, there are also certain important conceptual and empirical distinctions.

\section{Correlates of Humility}

In this section, I review the literature on the influence of humility in the context of both workplace behaviors and leadership.

\section{Humility and Workplace Behaviors}

I first review the influence of humility on general workplace behaviors. Most of the research on humility in the workplace has focused on its impact on decision-making and cooperative behaviors. For example, using students and lower level employees samples, humility was found to be positively related with fair decision making (Hilbig \& Zettler, 2009) and prosocial behaviors (Exline \& Geyer, 2004). Using a semiexperimental study, Hilbig and Zettler (2009) found that individuals who score high on the honesty-humility scale tended to act in a more cooperative fashion - they chose solutions that were fair for all, even when they could have defected without fearing negative consequences. Similarly, Hillbig, Zettler, Leist, and Heydasch (2013) found honestly-humility to be related to active cooperation, that is, "the tendency to be fair and genuine in dealing with others, in the sense of cooperating with others even when one might exploit them without suffering retaliation" (Ashton \& Lee, 2007, p. 156). In addition, honesty-humility has been found to be related to integrity-based outcomes such as ethical decision-making (Lee, Ashton, Morrison, Cordery, \& Dunlop, 2008). 
Individuals high on honesty-humility were also less likely to commit vengeful acts (i.e., "getting even") in reaction to transgressions or provocations (Lee \& Ashton, 2012). Similarly, honesty-humility has also been found to be related to several forgivenessrelated variables (Perugini et al., 2013; Shepherd \& Belicki, 2008; Sheppard \& Boon, 2012).

Johnson, Rowatt, and Petrini (2011) found that honesty-humility was predictive, over and above the other five traits included in the Big 5, of employee job performance (rated by superiors) in care giving roles. Their rationale was that since honesty-humility is associated with cooperativeness, as opposed to selfishness (Ashton \& Lee, 2001, 2007), more humble employees may outperform others in jobs that require more patience, understanding, and empathy. Honesty-humility was also found to predict lower levels of counterproductive work behaviors (Marcus et al., 2007), including workplace delinquency (Lee \& Ashton, 2005).

In sum, humble individuals appear to engage in more prosocial behaviors in the workplace, and tend to be ethical and fair in their decisions. Even though the aforementioned studies were not directly tested in the leadership context, similar arguments could be used to study leader humility. For example, is humility a predictor of ethical leadership? Considering humble individuals engage in more cooperative behaviors, are humble leaders more likely to include others in decision making? In the next section, I review the correlates of humility which have been tested specifically in the context of leadership. 


\section{Humility and Leadership}

In recent years, there has been a growing interest in studying humility in the context of leadership (Ou et al., 2014; Owens et al., 2013) and perhaps surprisingly, published articles on the topic are almost exclusively conceptual in nature (Owens \& Hekman, 2012). Leadership scholars have suggested that leader humility is important to organizational effectiveness (e.g., Morris et al., 2005; Owens \& Hekman, 2012, Vera \& Rodriguez-Lopez, 2004), but solid empirical evidence, to confirm the proposed relationships, is still lacking. For example, leader humility has been argued (but not empirically tested) to be related to organizational learning, organizational resilience (Vera \& Rodriguez-Lopez, 2004), follower engagement, relational trust and loyalty, psychological freedom, small continuous change (Owens \& Heckman, 2012), supportiveness toward others, socialized power motivation, participative leadership (Morris et al., 2005), and socialized charismatic leadership (Nielsen, Marrone, \& Slay, 2010).

Whereas the majority of what has been published is conceptual, some recent empirical studies have begun to uncover the potential correlates of leader humility. Here I limit my review to empirical papers that have directly tested the impact of humility on different outcomes. Even though humility is an important component of authentic leadership, those studies are not included here since their hypotheses refer to authentic leadership as a unified construct, and fail to disentangle the impact of each of the humility sub-facet.

Owens and colleagues (2013) is one of the rare published studies that directly tests for the outcomes of leader humility. Using a sample of 218 leaders from large U.S 
health services organizations, the authors found that leader expressed humility (operationalized as the common core of teachability, appreciation of others, and selfawareness) was positively related to a host of outcomes at the employee- and team-levels, namely job engagement, job satisfaction, retention, team learning orientation, and team member engagement. Their findings suggest that the receptivity to feedback, openness to learn, and the realistic view of oneself, which characterizes humble leaders, tends to create a positive work environment where followers feel engaged, satisfied, and open to constantly learn and adapt. Another recent paper by Ou, Su, Chiu and Owens (2014) found leader humility to be associated with follower perception of leader charisma. They argued that followers tend to perceive humble leaders as more charismatic, since they emphasize a followers' worth and are able to articulate a vision that is not for personal glory, but that also includes the interests of others.

Recently, in addition to identifying the potential correlates of humility, scholars have started to look at boundary conditions. The question is shifting from "Is humility an important characteristic for leaders to possess?" to "Under what conditions is humility likely to have a greater or more pronounced impact?." Followers' personality, cultural influence and status incongruence have all been examined as potential moderating conditions (Sun, 2014; Daniels, Greguras, Bashshu, \& Oc, 2014; Ou, Su, Chiu, \& Owens, 2014). For example, Daniels and colleagues (2014) argued (and found empirical support for) that humble leaders have a greater effect on high power distance followers, since it reduces the social distance between leaders and followers, thus increasing relationship quality and job satisfaction. 
In sum, literature on the correlates of leader humility has been mostly conceptual in nature (Owens et al., 2013; Owens \& Hekman, 2012). The few recent empirical studies suggested humble leaders are effective, in part, because they stimulate follower engagement and performance through a feeling of empowerment and close cooperation

(Ou et al., 2014). However, most published studies have focused on subjective outcomes at the individual level (e.g., job satisfaction, work engagement) (Ou et al., 2014; Owens et al., 2013), limiting our understanding of the impact of leader humility on more objective outcomes. In the next section, I discuss potential avenues to study humility in the Upper Echelons context, suggesting a different set of dependent variables (i.e., outcomes) since CEOs are a rare case where an individual's personality shows up in firmlevel outcomes.

\section{Humility in the Context of Upper Echelons Research}

In the last 30 years, research findings have consistently found evidence that organizational strategies and outcomes can be better comprehended by studying the characteristics of the senior executives who perceive, interpret, and make decisions on behalf of their organizations (Hambrick, 1984, 2007; Kaiser et al., 2008). Often referred to as the Upper Echelons Perspective, scholars have studied a wide array of CEO demographic characteristics, personality traits, values and cognitions - linking them to critical organizational-level outcomes (Finkelstein, Hambrick, \& Cannella, 2009). Even though in its original conceptualization (Hambrick, 1984), the emphasis was on all of the members of the top management team, the wide majority of Upper Echelons studies have 
focused on CEOs (Hiller \& Beauchesne, 2014) which are often argued to have a disproportionate and dominating influence on their firms (Hambrick, 1994).

An important stream of research within the Upper Echelons Perspective is the consequences of CEO's views of self on firm's strategies and outcomes. In other words, do the ways CEOs think of themselves have a tangible impact on their organizations' behaviors? Initial interest in the idea of CEO's self-view can be traced to the work of Richard Roll (1986) on the "hubris hypothesis" where he suggested overpayments for corporate acquisitions are the consequences of hubris on the part of the bidding CEOs. Empirical research on CEOs' views of self has focused mainly on hubris, narcissism, overconfidence and core self-evaluations (e.g., Chatterjee \& Hambrick, 2007, 2011; Hayward \& Hambrick, 1997; Li \& Tang, 2010; Resick et al., 2009; Simsek, Heavey, \& Veiga, 2010; Zhang, Peterson, \& Reina, 2013). Those traits, which can be considered the "high" end of the self-view spectrum, have been found to be predictive of a host of strategic outcomes. For example, CEO narcissism was found to predict glory-seeking behaviors such as large-scale strategic changes (e.g., acquisitions) that sometimes appear to be successful, and other times not so successful (Chatterjee \& Hambrick, 2007). A CEO's core self-evaluations (i.e., the global and stable evaluation one makes about one's own self-worth and capabilities) was found to be related to the firms' entrepreneurial orientations (Simsek et al., 2010).

While there is growing empirical evidence that those "high" end self-concept personality traits have important strategic implications for organizations (see Hiller \& Beauchesne, 2014, for a review), we have yet to fully explore how humility fits in the CEO's view of self literature. With the exception of Ou and colleagues (2014) who found 
that CEO humility was predictive of a host of positive subjective outcomes at the employee- (e.g., job satisfaction, organizational commitment) and team-level (e.g., top management team integration), we have a limited understanding of the strategic implications of humility in the context of executive leadership. In essay 3, I look at the potential relationship between CEO humility and objective firm-level outcomes.

In the next section, I suggest two avenues to move our understanding of the implications of humility in the Upper Echelons context forward: 1) the development of new ways to capture CEO humility and 2) the study of the strategic implications of CEO humility (i.e., its impact on objective firm-level outcomes).

\section{Measurement of CEO humility}

An important challenge associated with humility research has been the ability to reliably measure the construct and its different components (Morris et al., 2005). There appears to be two major impediments to studying humility in CEOs. First, is the issue regarding self-report measures of humility. Researchers have argued, for example, that individuals who report themselves as exceptionally humble may, paradoxically, be the opposite of humble (Morris et al., 2005; Ou et al., 2014). As a result, humility has often been argued to be measured best using other-report surveys (Ou et al., 2014; Tangney, 2000).

Second, the difficulty of measuring the construct adds to the already challenging task of getting access to CEOs to measure humility via self-reports, or the difficulty even of gaining access to others who know (and may be able to rate) a given CEO in the case of other-reported measures of humility. 
One potential alternative, which is gaining popularity in Upper Echelons research, is the development of unobtrusive measures (e.g., Chatterjee \& Hambrick, 2007, 2011; Hayward \& Hambrick, 1997). Unobtrusive measures are usually based on public information about CEOs, documentary sources, and/or their written and oral communications as ways to learn about their preferences and natural inclinations (Webb et al., 1966). The use of an unobtrusive measure is particularly appealing for the study of CEOs, considering their public status and extensive media coverage. The sensitive character regarding CEOs' views of self (and consequent low likelihood they would agree on participating in a survey on such a delicate topic) has motivated scholars to develop unobtrusive measures for both CEO narcissism and hubris (Chatterjee \& Hambrick, 2007, 2011; Hayward \& Hambrick, 1997; Li \& Tang, 2010). Using a similar approach, I suggest and validate an unobtrusive measure of humility in essay two.

In addition, the development and validation of an unobtrusive measure of humility may also contribute to the debate as to how humility relates to other traits, such as hubris and narcissism. Perhaps some indicators suggested to capture CEO narcissism may, in fact, be imperfect indicators of both narcissism and low humility. More importantly, new indicators capturing the different dimensions of humility should provide additional evidence of the uniqueness of the multi-faceted trait of humility.

\section{Strategic Outcomes of Humility}

Given the long history of evidence demonstrating that the characteristics of senior leaders manifest in the types of strategies their organizations pursue and outcomes that result, I suggest that the construct of humility might be another useful avenue for 
exploring strategic and performance outcomes of firms. In particular, the need for a longterm horizon and capacity to adapt to complex situations which characterize leadership at senior executive levels (Hiller \& Beauchesne, 2014) may be influenced by CEO humility - CEOs' orientation toward not seeking the spotlight, listening to others' advices, and constantly learning and adapting.

Most accumulated evidence in regards to humility (in both executive and nonexecutive settings) has focused on its impact on subjective outcomes such as job satisfaction, work engagement, and superior performance ratings (Ou et al., 2014; Owens et al., 2013). While several studies have suggested followers appreciate working for humble leaders, who often display a more participative and empowering style of leadership (Daniels, Greguras, Bashshur, \& Oc, 2014; Ou et al., 2014; Owens et al., 2013), we have yet to understand their impact on more objective organizational outcomes such as firm performance. The demonstration that humility also impacts objective performance outcomes appears critical in order for humility to be recognized as an important leadership characteristic.

CEO humility may also be linked to social outcomes at the firm-level. For example, considering humble CEOs are more likely to integrate the needs of different stakeholders (Ou et al., 2014), they may influence their organizations to be more ethical and socially responsible. Studying the influence of CEO humility on outcomes, such as corporate misconduct, earning restatements, environmental ratings and corporate social performance, represents interesting avenues for future research. In essay 3, I test the influence of CEO humility on both objective measures of performance and corporate social performance. 
An important challenge for researchers is to make sure the arguments used to link CEO humility to organizational-level outcomes are not merely the opposite of those used in the cases of narcissism or hubris. While there is growing evidence that humility is both conceptually and empirically distinct from other self-view traits, such as narcissism, CSE, and hubris (Ou et al., 2014; Owens et al., 2013), I suggest some of the confusion stands from the fact that the arguments used by scholars to link humility to different outcomes are often similar (and in some cases identical) to previous research on other self-view traits. As an example, Morris, Brotheridge, and Urbanski (2005) suggested that CEOs who possess humility behave in a way that is other-enhancing (as opposed to selfenhancing) and stay away from attention and public adulation. Similarly, Chatterjee and Hambrick (2007) suggested that narcissistic CEOs engage in attention-getting behaviors to gain the attention and admiration of the audience. While both statements may be true, the use of similar arguments in developing hypotheses can potentially lead readers to think humility is merely the opposite of narcissism. Thus, it appears critical for scholars interested in humility research to clearly state how humility is likely to impact the suggested outcomes beyond anti-narcissism. This could be done by examining how the different dimensions of humility are related to the outcomes of interest instead of focusing mainly on the low self-focus aspect of humility that considerably overlaps with anti-narcissism.

\section{Conclusion}

Considering recent findings suggesting that humility of individuals (and in particular those in positions of leadership) is related to a host of important 
behaviors/outcomes, it appears critical to conduct more research to explore how (and if) it is also associated with positive outcomes in the unique case of executive leadership, where the firm-level implications (and implications for employees, shareholders, and other stakeholders) are often truly significant. Conducting research on the strategic implications of CEO humility also responds to a recent call in literature to study objective outcomes of leader humility, for which most existing research has focused on subjective individual-level outcomes (Ou et al., 2014; Owens et al., 2013). In addition, the inclusion of humility in the Upper Echelons literature will hopefully broaden the discussion on the strategic implications of executive self-concept beyond the traditional dimensions of narcissism, hubris and CSE to provide a more rich and nuanced understanding of the delicate interplay and implications of executive self-concept. 


\title{
II. Development and Validation of an Unobtrusive Measure of CEO Humility
}

\begin{abstract}
In this second chapter, an unobtrusive measure of CEO humility is developed and validated. The partial indicators of humility are described and then validated using a self-reported survey administered to a sample of 30 U.S. and Canadian CEOs. Results suggest that CEO involvement in non-profit organizations and their acknowledgement of the importance of boards of directors to firm success, are both significantly and positively related to self-reported humility scores. Potential implications in moving CEO humility research forward are discussed.
\end{abstract}

\section{Introduction}

Previous research on the topic of leader humility has mainly been conceptual in nature (Owens \& Hekman, 2012) and the difficulty in measuring humility is often cited as one of the important reasons why empirical studies are rare (Ou et al., 2014; Owens et al., 2013). Developing new ways of measuring the construct of humility, that do not exclusively rely on self-reports, has been argued to be a critical task in order to move the research on humility forward (Exline et al., 2004; Ou, 2011; Owens, 2009; Tangney, 2002). Thus far, scholars have measured humility via self-reported, other-reported, and implicit measures. Self-reported measures have been greatly criticized because of the potential threat of social desirability, and have also been found to have a weaker validity than other-reported measures (Ou, 2011; Owens et al., 2013). In the Upper Echelons context, the difficulty in measuring humility adds to the already difficult task of either 
gaining direct access to CEOs in order to measure humility via self-reports or even gaining access to others who know (and may be able to rate) a given CEO in the case of other-reported measures of humility. In this essay, I suggest a number of ways that CEO humility may be indirectly estimated through reliably attainable data from public and proprietary sources, and examine evidence for the validity of these suggested observable indicators.

Upper Echelons theorists who are interested in studying the characteristics of senior executives, but without access to self-reported measures as is typically done in personality psychology, have relied on unobtrusive measures as a way of capturing senior executives' preferences and natural inclinations (Hayward \& Hambrick, 1997; Chatterjee \& Hambrick, 2007). Based on public information available about CEOs, documentary sources, and/or their written and oral communications (Webb et al., 1966), unobtrusive measures are particularly appealing when studying sensitive traits such as CEOs' views of self (Chatterjee \& Hambrick, 2007).

Unobtrusive measures are becoming more prevalent in Upper Echelons studies (Hiller \& Beauchesne, 2014), as a way to avoid low response rates usually associated with self- and other-reported CEO surveys (Cycyota \& Harrison, 2006) and to take advantage of the abundant information available on CEOs of publicly-traded companies. Unobtrusive measures have already been developed and are being used for other selfview traits, such as hubris and narcissism (Chatterjee \& Hambrick, 2007, 2011; Hayward \& Hambrick, 1997; Li \& Tang, 2010). While proxy (i.e., unobtrusive) measures have proven to have predictive validity, the extent to which they overlap (i.e., are correlated) 
with existing measures (i.e., convergent validity) is often left unanswered (Hiller \& Beauchesne, 2014).

In this study, I suggest and validate potential humility indicators using a sample of 30 CEOs. More specifically, I: 1) review existing methods used to measure humility; 2) describe potential unobtrusive humility indicators and their overlap with the different dimensions of humility; and 3) perform a validation study to assess the validity of the suggested unobtrusive indicators of humility.

\section{Existing Methods to Measure Humility}

The construct of humility has usually been assessed using three main types of measures: self-reports, other-reports, and implicit measures of humility.

Self-reported measures of humility have been severely criticized for their potential biases due to social desirability and their poor convergent and discriminant validities (Owens, 2009; Peterson \& Seligman, 2004; Rowatt et al., 2006; Tangney, 2002). In addition to the potential threat of social desirability, Owens and colleagues (2013) argued that self-reported measures of humility are conceptually inadequate individuals who rate themselves as exceptionally humble may, in fact, be the opposite of humble. While self-reported measures have been greatly criticized, Ou (2011) argued that the person themselves could best measure some dimensions of humility. Whereas close observers may be able to rate the more behavioral aspects of humility, they may fail to assess its more internal components (i.e., the motivational and cognitive aspects of humility). For example, close others may not be able to easily observe another's level of self-awareness. Ou (2011) developed a self- and other-reported measure of humility, 
which both showed an acceptable measurement model, high reliability, and convergent validity.

In order to circumvent the potential drawbacks of self-reported humility measures, scholars are increasingly using other-reported measures (e.g., Morris et al., 2005, Ou et al., 2014; Owens et al., 2013), such as Ou and colleagues (2014) who measured CEO humility through questionnaires administered to top management team (TMT) members. While other-reported measures have shown stronger validity than CEO self-reported measures of humility (Ou et al., 2014; Owens et al., 2013) using close others also raises some significant concerns. First, some dimensions of humility, such as self-awareness, are internal, making it difficult for close others to accurately rate a CEO. Thus, close others will potentially overemphasize the more behavioral aspects of humility, as opposed to the more cognitive/motivational components. This could partly explain why Owens (2009) found a much stronger correlation between humility and narcissism when measured via other-reports $(\mathrm{r}=-.64)$ as opposed to self-reports $(\mathrm{r}=$ .16) - close others may be using similar behavioral markers to assess both the humble and narcissistic tendencies of the ratee. Second, in the context of Upper Echelons studies, the use of other-reported surveys does not eliminate the threat of low-response rates since the executives that have direct relationships with CEOs (i.e., those who may be able to rate a CEO's humility) are just as likely to be difficult to reach as the CEOs themselves. In addition, not only may a CEO be reluctant to let their TMT or other members of their organizations report on their personality, but the use of other-reports causes investigators to obtain multiple responses (at least two) for each CEO included in their study, potentially leading to even lower response rates. 
Lastly, Rowatt and colleagues (2006) developed an implicit measure of humility, relying on the individual's reaction times in associating attributes, such as humility or arrogance, with the self or others. Humble individuals are expected to link humilityrelated concepts with the self more rapidly than arrogant-related concepts. Implicit measures cannot be easily faked or controlled by participants, which has been argued to be an advantage over self-reports when the threat for social desirability is high (Banse, Seise, \& Zerbes, 2001). Results from the implicit measure of humility have showed a positive significant correlation ( $\mathrm{r}=.26)$ with an explicit self-reported measure of humility - suggesting convergent validity (Rowatt et al., 2006). While the implicit measure of humility developed by Rowatt and colleagues (2006) is promising, it would be extremely difficult to persuade CEOs (especially of large publicly-traded firms) to participate in such a research project.

In sum, reliably measuring humility is still an unsolved problem in psychology (Tangney, 2002) and all three suggested methods of measurement possess important concerns. While self-reported measures may be biased due to social desirability, close others may potentially overemphasize the behavioral components of humility when measuring a ratee's humble tendencies (due to their incapacity to observe the more internal aspects of humility). Implicit measures of humility represent an interesting alternative to the traditional self- and other-reported measurement methods; however respondents may be reluctant to participate in research relying on implicit personality measures since they may feel uncomfortable with not having full control over how they are being portrayed (Rowatt et al., 2006). When possible, scholars should aim at collecting data on humility from multiple sources and examine how the different 
measures relate to one another. In the next section, I suggest potential unobtrusive humility indicators in response to the recent call in literature for new ways of measuring humility (Morris et al., 2005; Ou et al., 2014).

\section{Proposed Unobtrusive Indicators of Humility}

In order to identify unobtrusive humility indicators, two main search criteria were used. First, the indicator needed to capture one, or multiple, dimensions of humility. Second, the indicator needed to be substantially under the control of the CEO, such that

the indicator could be reasonably presumed to be representative primarily of the CEO and not external factors such as the industry, corporate structural characteristics, or others. After searching and reviewing potential data sources, I suggest below 10 possible indicators of humility. The proposed humility indicators are described below and organized here according to the presumed aspect of humility which the unobtrusive indicator represents. As previously discussed in Essay 1, those four dimensions are: developmental orientation/teachability, self-awareness, appreciation of others' strengths and contributions, and low self-focus. While indicators often fit more than one dimension of humility, they are herein classified within the dimension they most clearly capture.

\section{Developmental Orientation/Teachability}

\section{Education Level}

The level of formal education of top executives has been suggested to be a proxy for individuals' competencies and knowledge (Hambrick \& Mason, 1984; Wiersema \& Bantel, 1992) and has also been argued to reflect one's open-mindedness and propensity 
to explore new alternatives (Datta \& Rajagopalans, 1998). As such, an executive's educational level has been found to be associated with a receptivity to innovation (Becker, 1970; Kimberly \& Evanisko, 1981; Rogers \& Shoemaker, 1971). Similarly, humility (and its dimension of teachability) is said to encompass an open-mindedness, desire to learn, and openness to advice (Tangney, 2002). Teachability is often described as a person's absorptive capacity on an individual level, which is generally related to developmental readiness (Owens et al., 2013). As such, I expect a CEO's educational level to be positively correlated with humility (and its dimension of teachability).

Consistent with others who have examined this variable, CEO educational level was coded using an ordinal variable ranging from one to six - below high school, high school, college diploma, university, master's degree, and doctorate (e.g., Li \& Tang, 2010).

\section{Breadth of Educational Studies}

I introduce executives' breadth of studies as a new construct defined as the number of unique fields of study in one's academic career. While pursuing higher education may reflect a learning orientation, interest in pursuing studies in different fields also suggests a curiosity and desire to learn about different paradigms and ways of thinking. This intellectual curiosity is also an integral component of humility that suggests humble individuals have an open and receptive mind (Templeton, 1997). As a result, I expect a CEO's breadth of educational studies to be positively related to humility (and its dimension of teachability). 
Breadth of educational studies was coded as a count variable - for example, a CEO with an undergraduate degree in engineering followed by an Master in Business Administration would receive a "2" for two unique fields of study.

\section{Career Variety}

Career variety is defined as the range of distinct professional and institutional experiences (i.e., functional tracks, organizations, and industries) an executive has experimented prior to being appointed as CEO (Crossland, Zyung, Hiller, \& Hambrick, 2014). For example, a CEO who has worked his entire career in finance for the same organization would have a low career variety score as compared to a CEO who has assumed different responsibilities in multiple organizations and industries. Over time, the diversity in a CEO's functional and institutional experiences have been found to be significantly correlated to openness to experience (Crossland et al., 2014). The notion of openness to different ideas and feedback is central to humility and its dimension of teachability (Owens, 2009). As a result, I expect CEO career variety to be positively related with humility (and its dimension of teachability).

Following the methodology of Crossland and colleagues (2014), career variety was measured using three indicators: inter-firm mobility (i.e., total number of unique firms), inter-industry mobility (i.e., total number of unique industries), and functional area mobility (i.e., total number of unique functions). An overall career variety score was calculated for each $\mathrm{CEO}$ as the sum of the three indicators divided by the number of years the person worked prior to becoming CEO. 


\section{Self-Awareness}

\section{TMT Diversity}

TMT diversity is defined as how dissimilar (or similar) top management team members are in regards to several characteristics such as age, educational fields of study, gender, functional experiences, etc (Hambrick \& Mason, 1984). In literature, it has mainly been used as an indicator for diversity of information, perspectives, creativity, and innovation in decision-making (Wiersema \& Bantel, 1992). Research on CEO succession has shown that the appointment of new CEOs leads to important changes in TMT composition and function - CEOs appear to have considerable leeway when it comes to the composition of their TMTs (Pitcher, Chreim, \& Kisfalvi, 2000).

Humility and its component of self-awareness is often described as "know yourself, improve yourself and complement yourself" (Tjan, 2012). While the first two elements are hardly observable, we can examine how CEOs' surround themselves in their organizations via the composition of their TMTs. Self-aware individuals know that it is not possible for anyone to be above-average across all business-building traits and recognize the importance to be surrounded by the right complement of people (Tjan, 2012). As such, we would expect humble CEOs (who are characterized as self-aware) to pay particular attention to having the right mix of people in their TMTs. In addition, humble individuals value the unique contributions of others and see opportunities to learn and grow from them instead of perceiving them as threats (Owens, 2009; Owens et al., 2013). Thus, I expect humble CEOs to embrace diversity when it comes to the composition of their top management teams, and see diversity as an opportunity to gain access to different points of view and perspectives. 
Each firm TMT included all executives above the vice-president level (e.g., senior vice-president, executive vice-president, chief operating officer) (Michel \& Hambrick, 1992; Hambrick, Cho, \& Chen, 1996). TMT diversity was coded using two indicators: functional experience diversity and educational background diversity. First, TMT functional experience diversity was coded by determining the dominant functional track (i.e., function in which the TMT member has spent the greatest portion of his/her career) for each TMT member: 1) production-operations; 2) research and development (including engineering); 3) accounting and finance; 4) management and administration; 5) marketing and sales; 6) law; 7) personnel and labor relations; and 8) other (Michel \& Hambrick, 1992). Since functional experience was coded as a categorical variable, TMT functional diversity was computed using a diversity index (Blau, 1977). The second indicator of job-related diversity is TMT educational background diversity. Educational experience was coded as the academic major in the highest degree of education obtained by the TMT member. Following Wiersema and Bantel (1992), five educational specialization categories were used to classify each TMT member's educational experience: 1) arts; 2) sciences; 3) engineering; 4) business and economics; and 5) law. Since educational experience is also a categorical variable, a diversity index was developed for TMT educational diversity (Blau, 1977).

\section{Appreciation of others' strengths and contributions}

\section{CEO Acknowledgement of the Importance of other Stakeholders}

The first measure of appreciation of others was derived through content analysis of letters to shareholders. Company annual reports are opportunities for CEOs to report to 
shareholders on their organizations' performance and progress, but they also represent an opportunity for a CEO to showcase their management philosophies and styles (Chatterjee \& Hambrick, 2007). Communication specialists have agreed in saying CEOs are very attentive to the content and design of annual reports (Chatterjee \& Hambrick, 2007).

Letters to shareholders were analyzed to find any mention that the work and contribution of employees, TMT members or board members, was pivotal to firm success. The author manually coded all instances where the work of other stakeholders was acknowledged in the letters to shareholders. Manual coding was selected over automated content analysis, considering that the interest was not in the use of particular words, but more the general idea that the work and development of others was vital to organizational success.

The measure was operationalized as an ordinal variable $(0,1,2)$. CEOs received a "2" if they mentioned the importance of other stakeholders in multiple occasions, "1" if it was mentioned once, and a " 0 " when it was not mentioned at all. Two annual letters to shareholders were coded for each CEO (i.e., years two and three of a CEO's tenure). This operationalization was preferred since it distinguishes between letters which truly emphasize the importance of other stakeholders (coded as "2") versus the ones in which one generic sentence is included at the end to thank the employees for their hard work and commitment (coded as a "1").

\section{Photographs in Annual Reports}

The use of pictures in annual reports can also reveal some interesting information about a CEO's personality. As mentioned by Chatterjee and Hambrick (2007), CEOs are 
very attentive to the content of the annual report, especially regarding how they are being portrayed. As such, we can expect humble CEOs, characterized as having a low selffocus and an appreciation for others, to avoid big self-promoting pictures of themselves in annual reports. Humble CEOs are likely to prefer pictures of themselves along with other senior executives (displaying their appreciation for other key members in their organizations) or have no picture (consistent with their low self-focus and low need for self-advertisement).

The measure was coded as an ordinal variable (i.e., 1,2,3): CEOs received a " 3 " if there was no picture in the annual report or if the CEO was photographed with one or more senior executives; "2" if the CEO was photographed by himself but the picture was smaller than half of a page, and a " 1 " when the CEO was photographed by himself in a picture larger than half of a page.

\section{Low Self-Focus}

\section{Salary Ratio (Cash and Non-Cash Compensation)}

The first two proposed indicators of CEO low self-focus were coded as a CEO's cash compensation (and non-cash compensation) divided by the compensation of the second-highest executive in the firm. Prior research has suggested CEOs have considerable power when it comes to determining their own pay (Tosi \& Gomez-Mejia, 1989; Bebchuk \& Fried, 2004). Used as a measure of self-importance (Hayward \& Hambrick, 1997) and narcissism (Chatterjee \&Hambrick, 2007, 2011), CEO compensation, relative to other executives, reflects how important and valuable the CEO thinks he or she is compared to anyone else in the firm. Humble individuals, 
characterized as having a low self-focus, do not seek to reap excessive benefits and are less attracted by materialism or excessive luxury (Rowatt et al., 2006). Thus, I expect the disparity between CEO compensation (cash and non-cash) and that of the second-highest executive to be smaller for humble CEOs (Rowatt et al., 2006).

CEO's relative cash compensation was operationalized as the CEO's salary and bonus divided by that of the second-highest-paid executive. CEO's relative non-cash compensation was operationalized as the sum of the CEO's deferred income, stock grants, and stock options divided by that of the second-highest-paid executive.

\section{Participation on Non-Profit Boards}

The low self-focus, which characterizes humble individuals, also translates to a desire to serve a larger purpose than the self $(\mathrm{Ou}, 2011)$. Their pursuit in life is not about themselves but the larger community (Owens, 2009). As such, we would expect humble CEOs to put their business expertise to the service of others. Sitting on the boards of non-profit organizations is one way CEOs can give back to society. By participating on boards of non-profit organizations, CEOs have the opportunity to use their notoriety and business knowledge to the benefit of the society. I argue that such type of board membership would be privileged by humble CEOs who are characterized as having a desire to serve a greater purpose than the self.

A CEO's participation on boards of non-profits was coded as a binary variable "1" for CEOs with board memberships in one or multiple non-profits, and "0" otherwise. This operationalization was preferred to a count variable considering the data available in the different databases did not allow a clear determination of the level of commitment 
and time invested by CEOs in the different non-profits. For example, a CEO who is the chair of one non-profit may invest more time than another CEO who is a board member on two non-profits. Additionally, the binary operationalization showed great variability with $47 \%$ of the CEOs with board membership(s) on non-profits, and the remaining 53\% who are not associated with any non-profits.

\section{Validation Study}

To ensure the reliability and validity of the suggested unobtrusive measures, a validation study was conducted to examine their relationships with a self-report measure of humility. In a recent book chapter, Hiller and Beauchesne (2014) urged Upper Echelons scholars to pay more attention to the validation process of CEO personality proxies. They emphasized that showing predictive validity (i.e., finding a relationship between a proxy measure and firm-level outcomes) does not prove the proxy is measuring the underlying construct we are inferring it to measure. Is the size of a CEO's signature really measuring one's narcissistic tendencies (Ham et al., 2013)? Does having a pilot license a good proxy for CEO risk propensity (Cain \& McKeon, 2012)? In many cases, even though the rational may be compelling, there is very little empirical evidence offered as to the validity of the suggested inferences. More recently, there has been a few instances where proxy variables have been validated in a more systematic way. Chatterjee and Hambrick (2007) asked financial analysts to rate the narcissistic tendencies of a sub-sample of 35 CEOs. Ham and colleagues (2013) tested their measure with a sample of 53 MBA students correlating the NPI-16 (i.e., a common self-report measure of narcissism) to the size of the students' signatures. Considering proxy 
measures are developed in the first place to circumvent the difficulty to access CEOs, scholars need to be creative in finding ways to validate their unobtrusive measures. Although the validation process can be tedious, and sometimes only partial validation can be performed, the exercise is critical to the veracity of our assertions about the potential relationships between CEO personality traits and organizational outcomes.

\section{Validation Sample}

Collecting data directly from senior executives can be challenging and often leads to low response rates (Cycyota \& Harrison, 2006). Surveys on sensitive topics, such as CEO narcissism or humility, are likely to yield even lower response rates (Chatterjee \& Hambrick, 2007; Cycyota \& Harrison, 2006). In order to gain access to CEOs and maximize participation in this research study, a snowball sample was utilized. Snowball samples initially target a few informants who nominate, through their social networks, other participants who fit the eligibility criteria for a given study (Goodman, 1961). Snowball samples are considered acceptable to survey hard-to-reach populations or topics of sensitive nature (Biernacki \& Waldorf, 1981).

CEOs included in the validation study were recruited through three different channels: 1) personal contacts of authors; 2) personal networks of two Canadian CEOs; and 3) the FIU Center for Leadership's network. Through our different recruiting

channels, 52 CEOs were invited to participate in the study (see invitation email letter in Appendix A) - 17 CEOs via the FIU Center for Leadership, 27 CEOs via the personal 
networks of two Canadian CEOs, and 8 CEOs via the personal contacts of authors. 30 CEOs completed the online survey for a response rate of 58 percent.

In exchange for their participation in the study, participants were offered a report of the main findings, following the completion of the research project. As a further inducement for companies/CEOs, I sent a "2014 FIU Partner-In-Research Seal" to those CEOs who requested the seal after survey completion. At their discretion, companies were granted permission to display this seal on corporate documents/websites. No financial compensation was offered to participants.

The means for revenues and full-time employees for the companies included in the validation sample are respectively $\$ 25 \mathrm{M}$ and 100 employees. Two companies were identified as not-for-profits and the remaining 28 companies were for-profit organizations. The sample comprised six U.S. and 24 Canadian firms. The average age of the CEOs was between 50 and 54 years old. In addition, $60 \%$ of them were both the CEO and chair of the board, and $60 \%$ were founding members of their organizations. Distribution tables for the revenues, number of employees and industry of the participating firms can be found in Figures 2, 3 and 4. 
Figure 2: Validation Sample - Firm Revenues Distribution

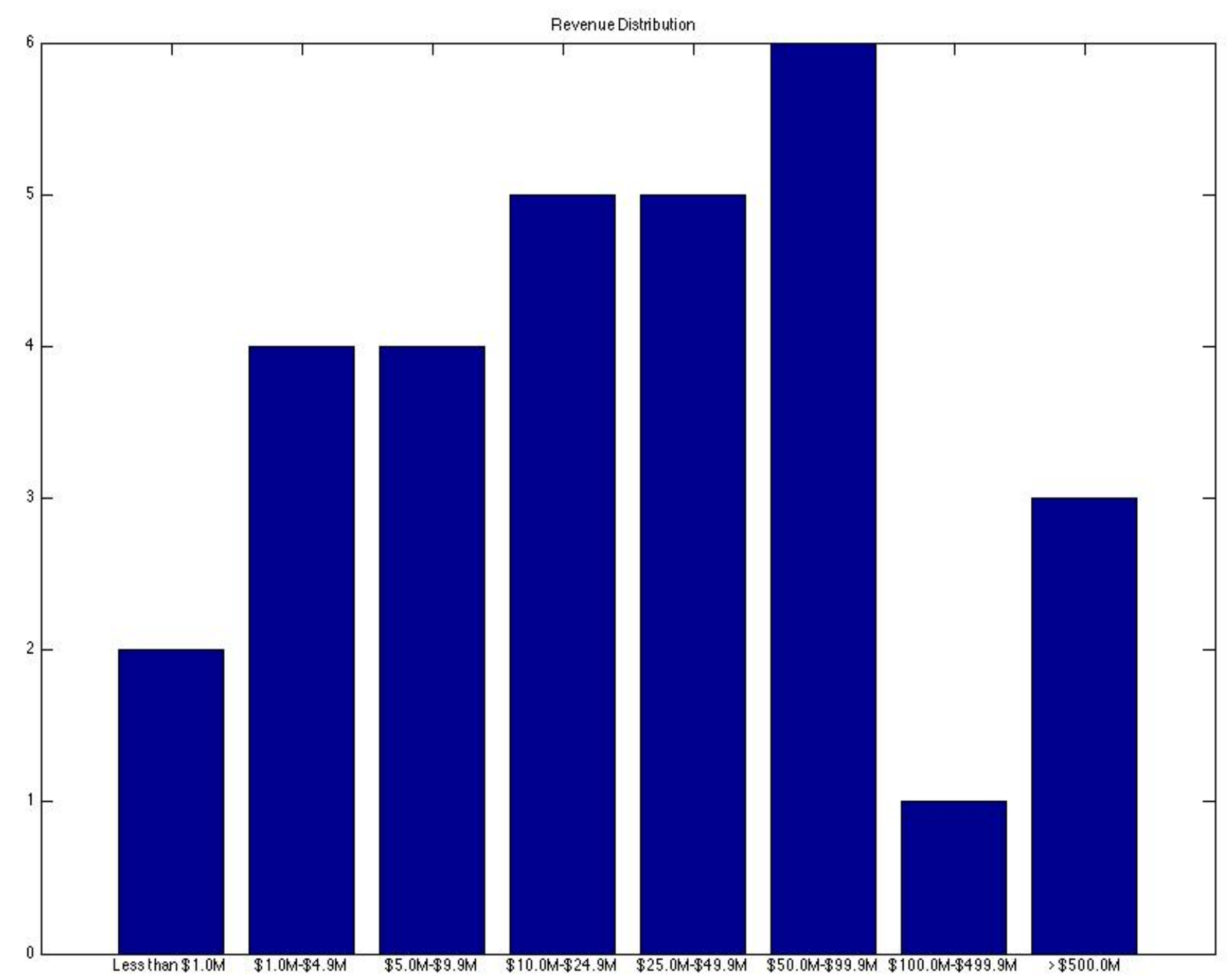


Figure 3: Validation Sample - Total Number of Employees Distribution

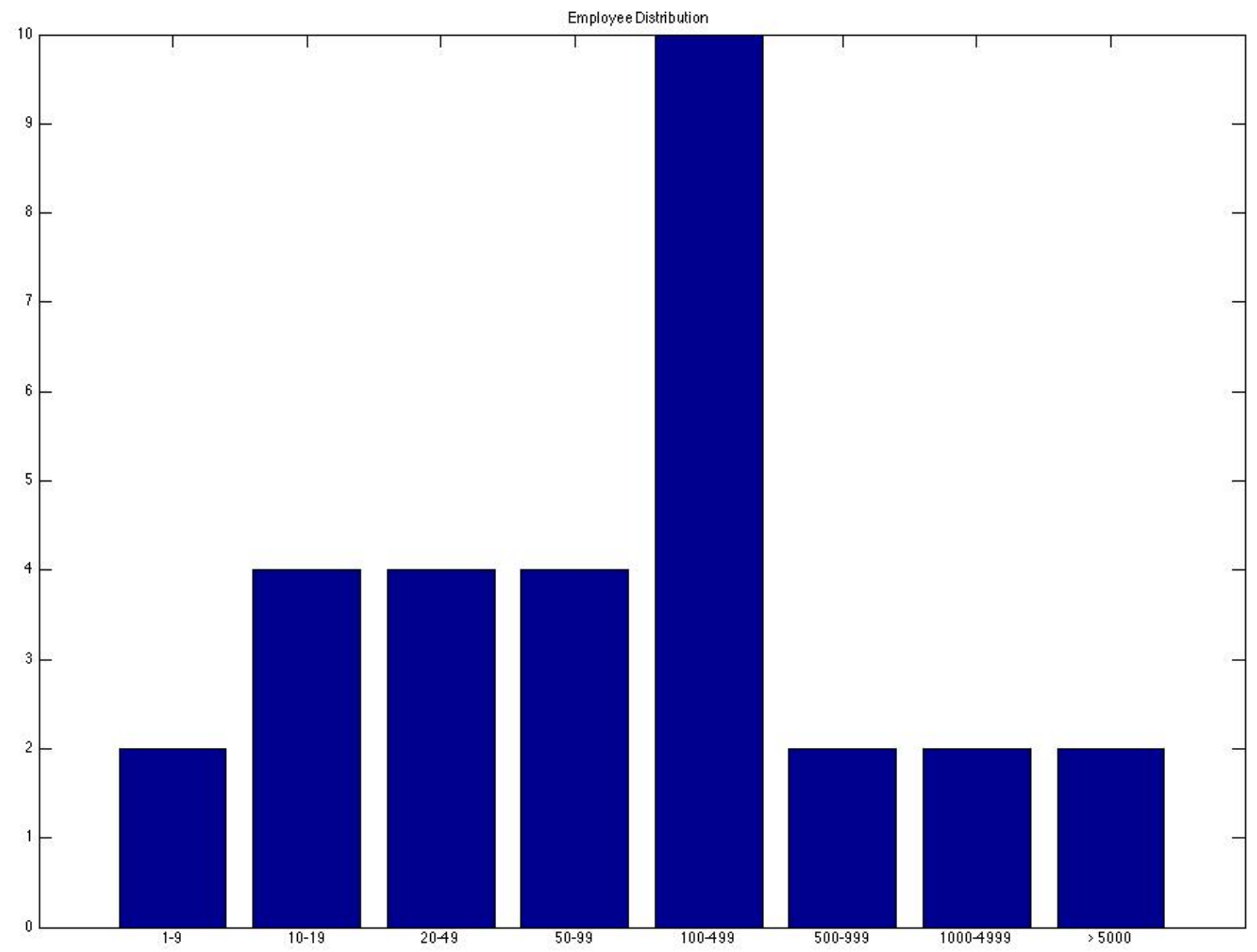


Figure 4: Validation Sample - Industry Distribution

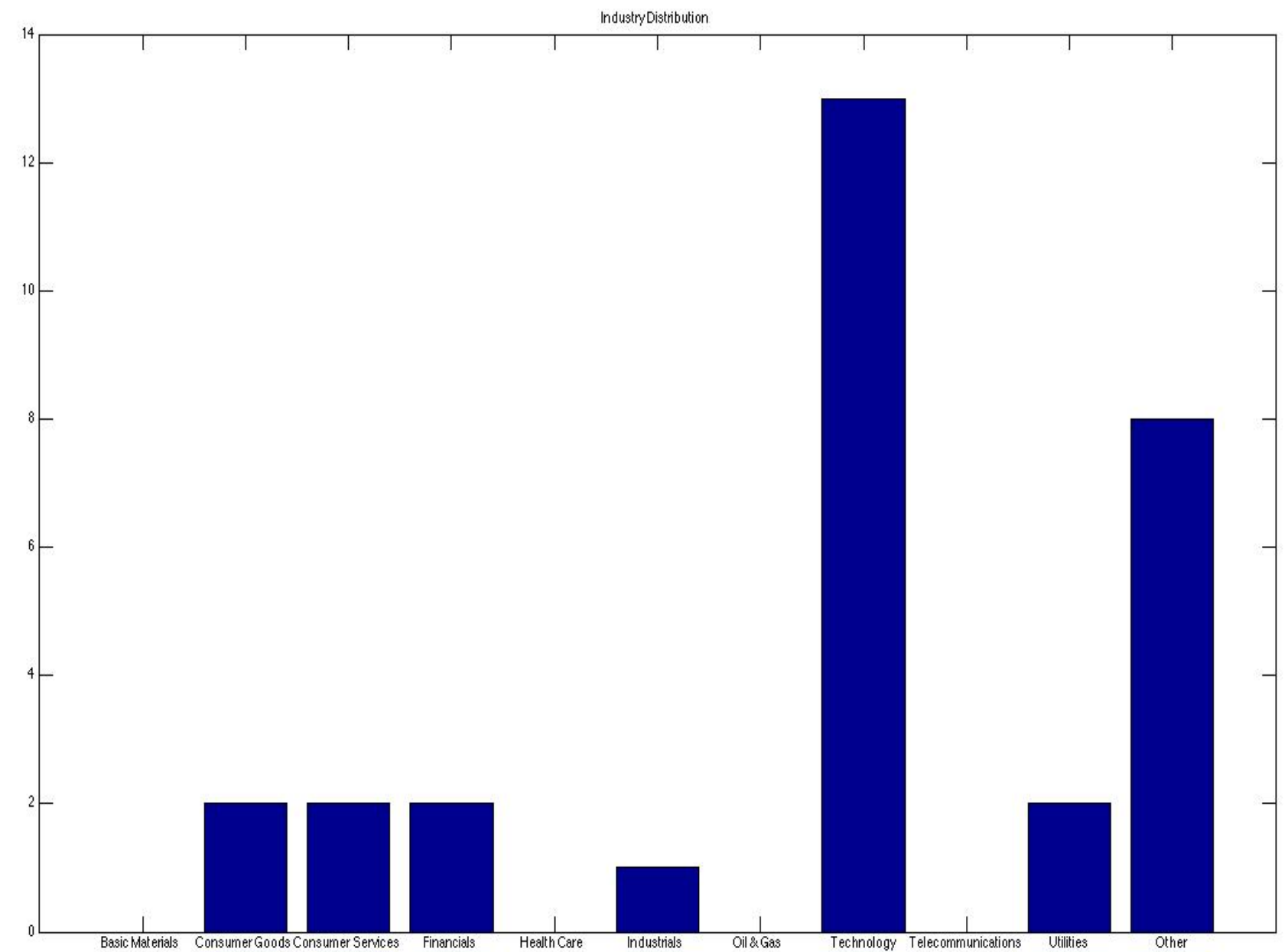




\section{Measures}

\section{Humility Scale}

Humility was measured using items from Owens and colleagues (2013) and $\mathrm{Ou}$ and colleagues (2014). Each of the four dimensions of humility (i.e., self-awareness, appreciation of others' strengths, teachability, and low self-focus) were measured using three items and CEOs had to choose a response that ranged from "strongly agree" to "strongly disagree" (i.e., 5-point scale). Overall humility scores were calculated by taking the mean score across all 12 individual humility items. Analyses were also run exclusively using the nine humility items suggested by Owens and colleagues (2013) (which exclude the low self-focus dimension).

\section{Other Traits}

In order to evaluate convergent and discriminant validity, measures of narcissism, openness to experience, extraversion, and emotional stability were also included in the survey. Considering that CEOs often do not have time to complete lengthy surveys, brief validated scales were preferred. Narcissism was measured using the NPI-16 (Ames, Rose, \& Anderson, 2006), the questionnaire is based on 16 forced choices - one narcissistic option and one non-narcissistic option. The NPI scores were calculated using the mean score across all 16 items. Three dimensions of the Big 5 - openness to experience, extraversion, and emotional stability - were measured using two items each (Gosling, Rentfrow, \& Swann, 2003). The six Big 5 items were measured using a 5-point scale (i.e., "strongly disagree" to "strongly agree") structure. Humility was expected to show a weak to moderate negative correlation with narcissism, since both include in their 
definitions the individual's propensity to be self-centered as opposed to other-centered (i.e., low self-focus dimension). A weak positive correlation was expected between humility and emotional stability, since humble individuals are characterized as having a stable sense of self-worth and self-respect (Owens, Rowatt, \& Wilkins, 2011; Vera \& Rodriguez-Lopez, 2004). A weak positive correlation was also expected with openness to experience since the teachabilty/openness to learn dimension of humility also captures an individual's interest and openness to different ideas and ways of doing things (Owens et al., 2013). Lastly, no relationship was hypothesized for extraversion.

\section{Unobtrusive Indicators of Humility}

Considering that the validation sample comprised mostly of CEOs at the helm of small- and medium-sized private firms (which do not publish annual reports or letters to shareholders), the indicator relative to the size of the CEO's photograph in the annual report could not be validated. For other indicators, items were developed to obtain similar information about the CEOs in our sample to what is usually found online or via different databases for the CEOs of publicly-traded companies. As an example, traditionally, Upper Echelons scholars have measured CEOs relative compensation using data on executive compensation available on Execucomp (only available for publicly-traded companies that have to disclose the total compensation of their top five executives). Considering the nature of the organizations included in the validation sample (and consequent unavailability of secondary data), an item was developed to capture CEOs relative compensation - "What was the ratio between your total compensation (salary, bonuses, equity, etc.) and the total compensation of the second-highest-paid executive in 
your firm last year?" Items were also developed to capture CEO career variety, CEO breadth of educational studies, CEO education, CEO involvement in non-profits, CEO acknowledgement of the importance of other stakeholders to firm success, and top management team diversity (see Appendix B for all survey items).

\section{Other Variables}

The survey also included additional variables at the CEO- and firm-level. CEO's age, tenure as CEO, founding status, inside versus outside appointment, and duality (i.e., the extent to which the CEO is also the chair of the board) were incorporated into the survey. Information about firms' revenues, number of employees, main industry and forprofit versus not-for-profit status were also obtained.

\section{Results}

The results of the validation study are described below. I present: 1) the means and variability measures for the different variables (i.e., items and scales); 2) the structure and reliability of the self-report humility measure; 3) the relationships among humility and other traits in its nomological network; and 4) the correlations between the selfreported measure of humility and the unobtrusive humility indicators.

\section{Mean and Variance of Variables}

There are a few notable findings regarding means and standard deviations of the study variables (Table 1). First, participants' scores on the humility self-reported measure show low variability with a standard deviation of .41 (mean $=4.5$ out of 5 and 
coefficient of variation $=9 \%$ ). While we may expect the self-reported scores on humility to be slightly inflated by social desirability, narcissism (which is also a very sensitive trait) showed more variability (mean $=.32$ out of 1 and coefficient of variation $=59 \%$ ). Coefficients of variation for emotional stability (mean $=3.95$ out of 5 and coefficient of variation $=23 \%)$, extraversion $($ mean $=3.48$ out of 5 and coefficient of variation $=33 \%)$, and openness to experience $($ mean $=4.13$ out of 5 and coefficient of variation $=17 \%)$ were also greater than for humility.

Table 1: Validation Sample Descriptive Statistics \& Reliability Analyses

\begin{tabular}{|l|c|c|c|}
\hline & Mean & $\begin{array}{c}\text { Standard } \\
\text { Deviation }\end{array}$ & $\begin{array}{c}\text { Cronbach's } \\
\text { Alpha }\end{array}$ \\
\hline Humility (4 dimensions) & 4.35 & .36 & .751 \\
Humility (3 dimensions) & 4.5 & .41 & .877 \\
Self-Awareness & 4.54 & .40 & .583 \\
Appreciation Others & 4.47 & .693 \\
Teachability & 4.49 & .843 \\
Low Self-focus & 3.89 & .89 & .864 \\
Narcissism & .32 & .19 & .718 \\
Emotional Stability & 3.95 & .89 & .558 \\
Extraversion & 3.48 & 1.15 & .833 \\
Openness & 4.13 & .69 & .215 \\
\hline Level of Education & 4.23 & .82 & \\
Unique Fields of Studies & 1.55 & .69 & \\
Career Variety & 10.17 & 3.80 & \\
Ratio Compensation & 3.80 & 1.94 & \\
Non-Profit s & .63 & .49 & \\
Importance TMT & 4.70 & .60 & \\
Importance Employees & 4.80 & .41 & \\
Importance Board & 3.67 & 1.06 & \\
TMT Education Diversity & 2.29 & 1.23 & \\
TMT Functional Diversity & 2.30 & & \\
\hline
\end{tabular}


Figure 5: Validation Sample Boxplot - Measure of Variability

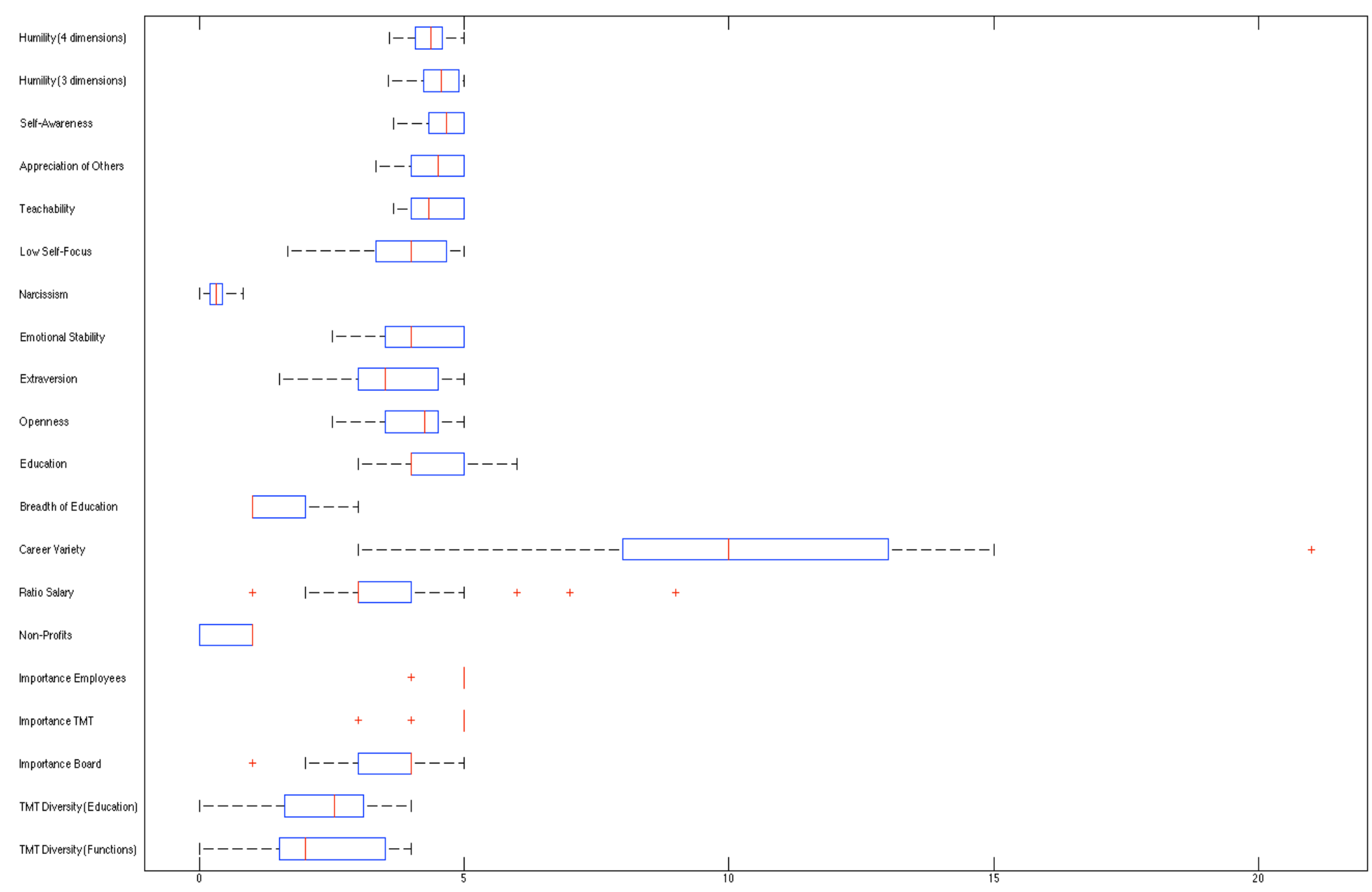


In figure 5, in the boxplot we can observe that two variables - CEOs' ratings of the importance of employees and top management teams to organizational success show almost zero variability. In other words, with the exception of one participant in the case of the importance of employees and two participants in the case of the importance of top management teams, all respondents rated the contribution of these two groups of stakeholders to organizational success as "very important". Interestingly, the importance of a third group of stakeholders (i.e., boards) generated more variability (mean $=3.67$ out of 5 and coefficient of variation $=29 \%$ ). 
Table 2: Validation Sample Correlations

\begin{tabular}{|c|c|c|c|c|c|c|c|c|c|c|c|c|c|c|}
\hline Variables & 1 & 2 & 3 & 4 & 5 & 6 & 7 & 8 & 9 & 10 & 11 & 12 & 13 & 14 \\
\hline Humility (4 dimensions) & 1 & & & & & & & & & & & & & \\
\hline Humility (3 dimensions) & $.801 * *$ & 1 & & & & & & & & & & & & \\
\hline Self-Awareness & $.754 * *$ & $.846^{* *}$ & 1 & & & & & & & & & & & \\
\hline Appreciation Others & $.633 * *$ & $.867 * *$ & $.534 * *$ & 1 & & & & & & & & & & \\
\hline Teachability & $.757 * *$ & $.945^{* *}$ & $.767 * *$ & $.736^{* *}$ & 1 & & & & & & & & & \\
\hline Low Self-Focus & $.533 * *$ & -.079 & .060 & -.171 & -.075 & 1 & & & & & & & & \\
\hline Narcissism & $-.327 \dagger$ & -.133 & -.145 & -.103 & -.110 & $-.357 *$ & 1 & & & & & & & \\
\hline 8. $\quad$ Emotional Stability & $.364 *$ & .103 & .193 & -.076 & .175 & $.462 * *$ & -.188 & 1 & & & & & & \\
\hline 9. $\quad$ Extraversion & -.191 & .182 & .147 & .211 & .127 & $-.576^{* *}$ & $.472 * *$ & -.211 & 1 & & & & & \\
\hline 10. Openness & .198 & $.378^{*}$ & .270 & $.470 * *$ & .256 & -.205 & .161 & 0.067 & .273 & 1 & & & & \\
\hline 11. Education & -.053 & -.112 & -.051 & -.146 & -.093 & .071 & .109 & -.149 & .041 & -.209 & 1 & & & \\
\hline 12. Unique Fields Study & -.068 & .124 & .089 & .084 & .154 & -.286 & .053 & -.124 & .291 & .057 & $.561 * *$ & 1 & & \\
\hline 13. Career Variety (Avg) & .029 & -.031 & -.116 & .068 & -.051 & .093 & .129 & .201 & -.011 & $.312 f$ & -.135 & .015 & 1 & \\
\hline 14. Ratio Salary & -.127 & -.154 & -.153 & -.115 & -.147 & .007 & -.100 & .263 & -.040 & .046 & $-.318 t$ & -.070 & -.169 & 1 \\
\hline 15. $\quad$ Non-Profit & .264 & $.343 \dagger$ & .294 & .231 & $.387^{*}$ & -.045 & -.074 & $.390^{*}$ & -.103 & $.301 f$ & .049 & .056 & .127 & -.080 \\
\hline 16. Importance TMT & .064 & .186 & $.326 \dagger$ & .115 & .086 & -.156 & .029 & .262 & .295 & $.308 \mathrm{f}$ & -.064 & -.052 & .099 & .245 \\
\hline 17. Importance Employees & -.114 & .005 & .057 & -.023 & -.011 & -.196 & .084 & -.076 & .251 & -.147 & -.062 & -.087 & $-.469 * *$ & .254 \\
\hline 18. Importance Board & $.361 *$ & $.375^{*}$ & $.31 \mathrm{f}$ & $.342 \dagger$ & $.344 \mathrm{f}$ & .071 & -.164 & .036 & .108 & .109 & -.186 & -.196 & -.131 & -.117 \\
\hline 19. TMT Diversity (Education) & -0.03 & -.03 & -.144 & .133 & -.089 & -.008 & -.077 & .130 & .112 & .078 & .190 & .081 & .214 & .179 \\
\hline 20. $\quad$ TMT Diversity (Functions) & -.160 & -.151 & -.121 & -.106 & -.173 & -.052 & .162 & .076 & .067 & -.008 & .186 & -.191 & .194 & .264 \\
\hline 21. Number Employees & -.051 & -.122 & -.021 & -.055 & -.231 & .087 & .105 & .041 & .011 & -.180 & .082 & -.139 & -.076 & .161 \\
\hline 22. Revenues & -.086 & -.203 & -.056 & -.177 & -.284 & .143 & .089 & .167 & .018 & -.231 & .225 & -.135 & .053 & .157 \\
\hline 23. Duality & -.042 & .008 & .093 & -.086 & .028 & -.080 & -.183 & -.163 & -.012 & -.140 & -.102 & .168 & -.073 & .200 \\
\hline Age & .155 & .009 & -.061 & .006 & .065 & .246 & .015 & -.037 & $-.430^{*}$ & -.212 & .006 & -.044 & -.112 & -.113 \\
\hline 25. CEO Tenure & -.203 & -.130 & .080 & -.259 & -.133 & -.154 & -.025 & -.046 & .095 & -.128 & -.064 & $.409 *$ & -.149 & $.310 \mathrm{f}$ \\
\hline
\end{tabular}

\begin{tabular}{|c|c|c|c|c|c|c|c|c|c|c|c|}
\hline Variables & 15 & 16 & 17 & 18 & 19 & 20 & 21 & 22 & 23 & 24 & 25 \\
\hline 15. Non-Profit & 1 & & & & & & & & & & \\
\hline 16. Importance TMT & $.319 \mathrm{f}$ & 1 & & & & & & & & & \\
\hline Importance Employees & -.208 & .028 & 1 & & & & & & & & \\
\hline 18. Importance Board & .287 & .273 & -.080 & 1 & & & & & & & \\
\hline TMT Diversity (Education) & -.079 & .233 & .126 & -.145 & 1 & & & & & & \\
\hline TMT Diversity (Functions) & -.034 & $.463 * *$ & .166 & -.024 & $.641^{* *}$ & 1 & & & & & \\
\hline Number Employees & .212 & .215 & -.135 & -.029 & -.031 & .185 & 1 & & & & \\
\hline 22. Revenues & .284 & .293 & -.135 & -.086 & .067 & $.321 f$ & $.914 * *$ & 1 & & & \\
\hline 23. Duality & $-.480 * *$ & -.070 & .272 & -.130 & -.025 & -.034 & $-.331 f$ & $-.392 *$ & 1 & & \\
\hline 24. Age & .071 & -.299 & -.221 & -.128 & $-.406^{*}$ & $-.444 *$ & .175 & .080 & -.232 & 1 & \\
\hline 25. CEO Tenure & -.056 & -.005 & .045 & -.231 & -.104 & .163 & .065 & .024 & .197 & .040 & 1 \\
\hline
\end{tabular}

Note: (f) Indicates a significance level of less than $0.1 ;\left(^{*}\right)$ less than $0.05 ;\left(^{* *}\right)$ less than 0.01 
Figure 6: Standardized Estimates - Confirmatory Factor Analysis (Humility 4 dimensions)

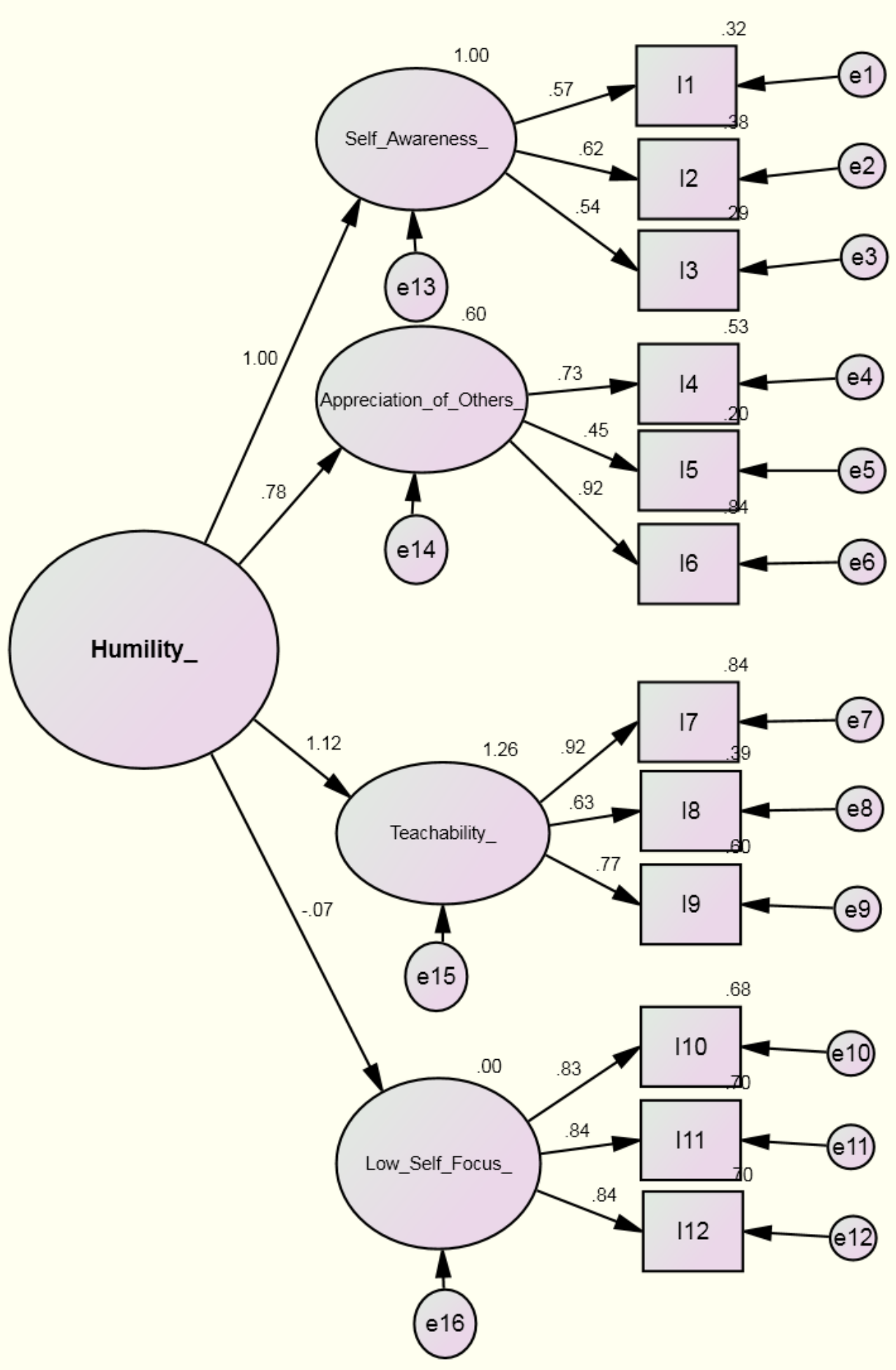


Figure 7: Standardized Estimates - Confirmatory Factor Analysis

(Humility 3 dimensions)

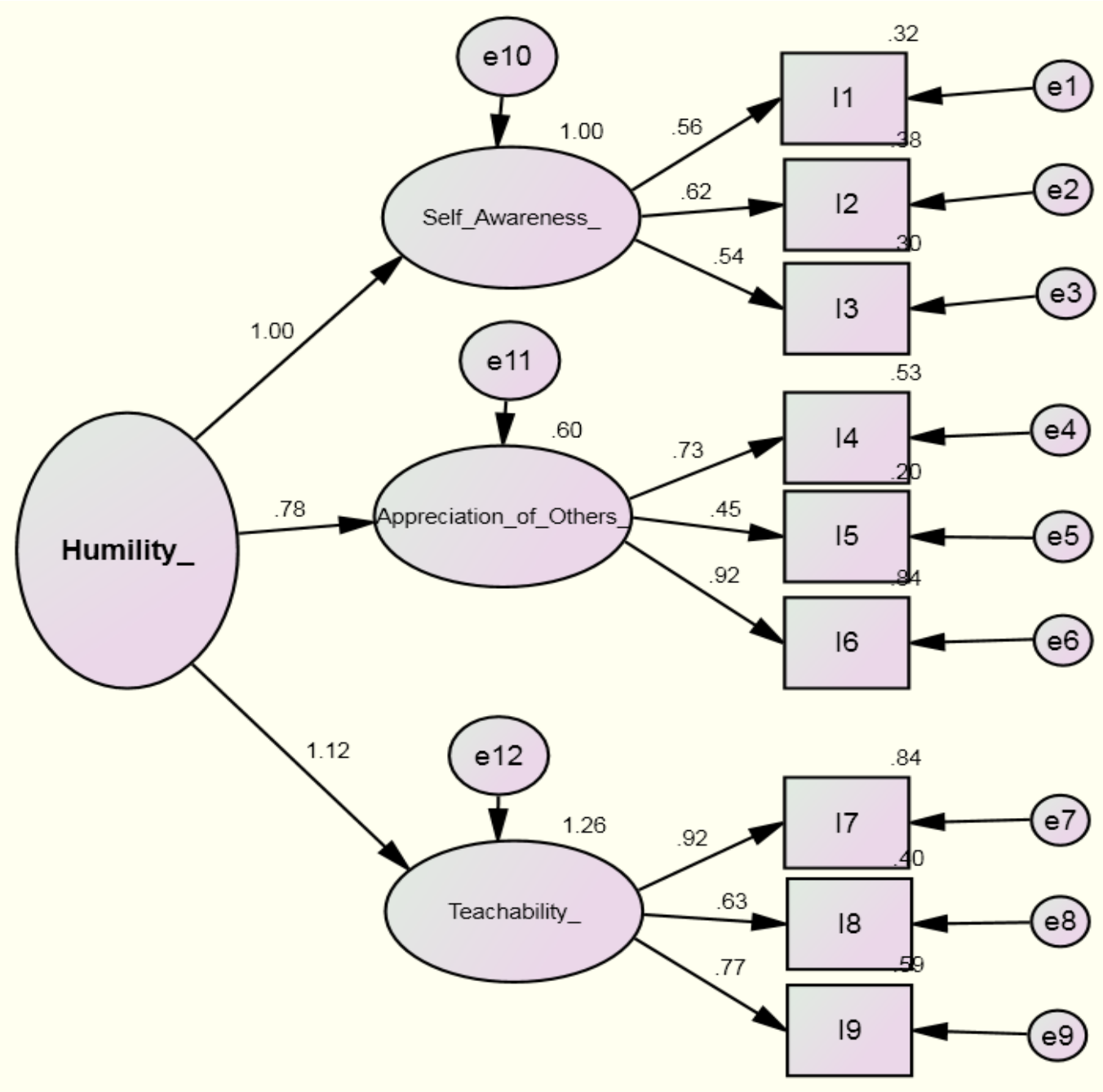




\section{Self-Reported Humility Measure}

With the exception of the low self-focus dimension of humility, inter-correlations among the three other dimensions of humility were fairly high (ranging from .53 to .77 ). Low self-focus was not significantly correlated with the other three dimensions (ranging from -.17 to .06). Overall humility scores were computed using both Owens' (2009) four dimensions and Owens and colleagues' (2013) three dimensions (excluding low selffocus) humility definitions. The correlation between the two self-reported humility measures (3 dimensions and 4 dimensions) was .80. The Cronbach's Alpha (Table 1) was higher for the 9-item (three dimensions) conceptualization of humility than the 12-item (four dimensions) conceptualization of humility (.88 as opposed to .75). Confirmatory Factor Analyses (CFA) were performed for both the three dimensions (Figure 7) definition of humility (Owens et al., 2013) and the four dimensions (Figure 6) definition of humility (Owens, 2009). Both measures had acceptable measurement model goodness of fit indices $(\mathrm{CFI}=.95, \mathrm{TLI}=.92, \mathrm{RMSEA}=.09$ for the three dimensions measure of humility; $\mathrm{CFI}=.92, \mathrm{TLI}=.90, \mathrm{RMSEA}=.09$ for the four dimensions measure of humility), although the three dimensions humility scale showed slightly better fit indices. Evaluation of the fit indices was based on the cutoff values of .1 for RMSEA (Browne \& Cudeck, 1993) and .90 for CFI and TLI (Hu \& Bentler, 1998).

Considering the Cronbach's Alpha and CFA fit indices were superior for the three dimensions humility scale (Owens et al., 2013), subsequent results are reported based on CEOs' scores on the 9-item humility scale. 
Humility, as expected, was unrelated ( $\mathrm{r}=.009$, non-significant) with CEO age, which is consistent with the premise that humility is a fairly stable personality trait. In addition, humility was not significantly related to firm size (operationalized as total number of employees) - suggesting humility is not situational ( $\mathrm{r}=-.122$, non-significant). In other words, it does not appear that CEOs of larger organizations are more or less humble than CEOs of smaller organizations.

\section{Nomological Network: Convergent and Discriminant Validity}

Humility (Owens et al., 2013) and narcissism (NPI-16) showed a weak nonsignificant correlation ( $\mathrm{r}=-.133$, non-significant $)$ - adding to the growing evidence that humility is not merely the opposite of narcissism (Ou et al., 2014; Owens et al., 2013). However, narcissism was found to be negatively related to low self-focus ( $\mathrm{r}=-.357$, $\mathrm{p}<.05$ ) which is included in several humility definitions (e.g., Ou et al., 2014; Owens, 2009; Tangney, 2002). Narcissism was also negatively related to the 4-dimension scale of humility which includes low self-focus $(\mathrm{r}=-.327, \mathrm{p}<.05)$. Correlations between humility and emotional stability, extraversion, and openness respectively were .103 (nonsignificant), .182 (non-significant), and .378 $(\mathrm{p}<.05)$. Thus, the nomological and discriminant validity of the humility measure showed adequate support.

\section{Validation of Unobtrusive Indicators:}

Humility measured using Owens and colleagues' 2013 scale was significantly related (in the hypothesized direction) to two unobtrusive humility indicators. First, 
humility was positively related to $\mathrm{CEO}$ involvement in non-profit organizations $(\mathrm{r}=.343$, $\mathrm{p}<.05$ one-tailed). When using only CEOs of firms with revenues of $\$ 1 \mathrm{M}$ and higher (eliminating start-ups), that correlation goes up to .386 ( $\mathrm{N}=28, \mathrm{p}<.05$ two-tailed). Second, humility was positively related to the CEO acknowledgement of the importance of boards to organizational success ( $r=.375, \mathrm{p}<.05$ one-tailed). Similarly, using hierarchical cluster analysis, the dendogram in Figure 8 shows how CEO involvement in non-profits and CEO acknowledgement of the importance of boards pertain to the same cluster than humility - suggesting that those three variables exhibit similar distribution of correlation coefficients. In other words, CEOs tended to respond similarly to these three variables. The following indicators were not significantly related to self-reported humility: level of education ( $\mathrm{r}=-.112$, non-significant), breadth of education ( $\mathrm{r}=.124$, non-significant), career variety ( $\mathrm{r}=-.031$, non-significant), ratio salary $(\mathrm{r}=-.154$, non-significant), CEO acknowledgement of the importance of employees to organizational success ( $r=.005$, nonsignificant), CEO acknowledgement of the importance of top management teams to organizational success $(\mathrm{r}=.186$, non-significant), top management team educational diversity ( $\mathrm{r}=-.03$, non-significant), and top management team functional diversity ( $\mathrm{r}=-$ .151 , non-significant). 
Figure 8: Validation Sample Hierarchical Cluster Analysis

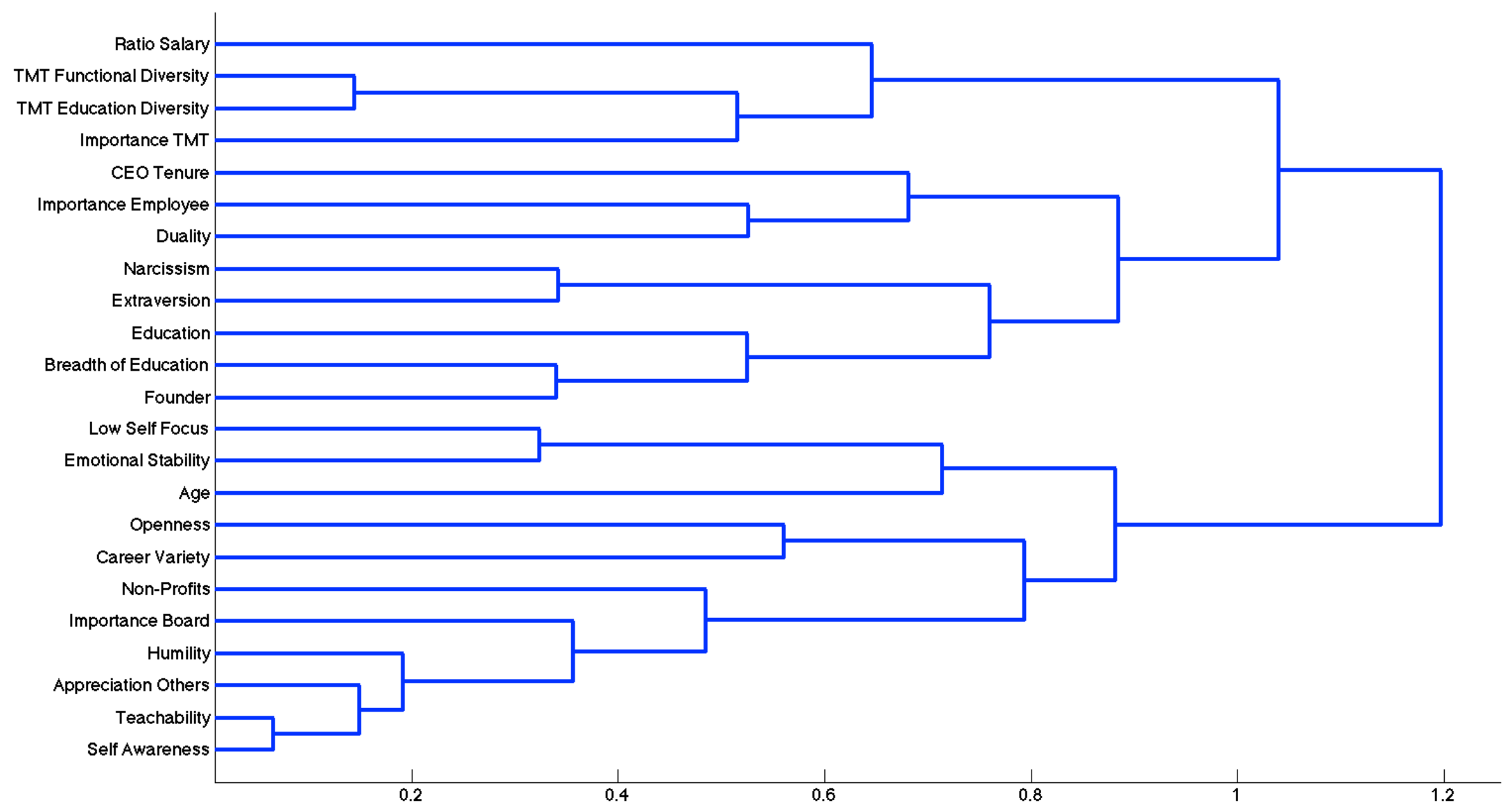




\section{Discussion and Conclusion}

This validation study provided support for two unobtrusive indicators of humility: CEO participation in non-profits and CEO acknowledgement of the importance of boards (i.e., other stakeholders) to organizational success. The involvement of humble CEOs in non-profit organizations reinforces the idea that humbler individuals tend to be otherfocused as opposed to self-focused, and engage more in self-transcendent pursuits (Ou et al., 2014). Considering board memberships on non-profits for CEOs of publicly-traded companies can be found via different online sources and databases (e.g., Bloomberg Database, Businessweek Executive Profiles, NNDB website, etc.), this opens up several avenues for future research for Upper Echelons scholars.

The positive significant correlation found between CEO acknowledgement of the importance of boards and CEO self-reported humility also has important implications. It suggests humbler CEOs perceive more value in the input of boards and see their insights as critical to firm success. This is aligned with the definition of humility that suggests humble individuals appreciate and value (as opposed to feel threatened by) the work and contributions of others (Exline et al., 2004; Owens, 2009; Tangney, 2002). While (almost) all the CEOs in the sample rated the other two groups of stakeholders (employees and top management teams) as "very important" to organizational success, more variability was observed when rating the importance of boards. Boards are quite different from TMTs and employees, in regards to their power relationships with CEOs their responsibilities include hiring and firing CEOs, as well as providing CEOs with strategic advice and counsel (Arthaud-Day, Certo, Dalton, \& Dalton, 2006; Daily, Dalton, \& Cannella, 2003; Zald, 1969). Less humble CEOs may not be as receptive to the 
input from their boards and might feel threatened by them - potentially explaining why they rated them as less important.

In sum, the results show preliminary evidence that humbler CEOs tend to rate at least one group of stakeholders as more important - boards of directors. Considering the two items developed to measure how important CEOs think employees and TMTs are to organizational success exhibited no variability, conclusions cannot be inferred for these two groups of stakeholders. All CEOs emphasized the importance of the "team effort" to organizational success, potentially due to social desirability. Content analysis of letters to shareholders to find all instances where the CEO acknowledges the importance of other stakeholders to firm success is likely to be a superior measure (and exhibit more variability). I encourage researchers to use that method whenever possible (i.e., when dealing with CEOs of publicly-traded firms).

Several limitations of the validation study may at least partly explain why I did not find clear support for the other unobtrusive measures of humility. First, the sample was relatively small $(\mathrm{N}=30)$ as is often the case in validation studies of CEOs unobtrusive indicators (e.g., $\mathrm{N}=35$ for Chatterjee \& Hambrick, 2007). Both CEO compensation compared to the second-highest-paid executive and CEO breadth of education (i.e., number of unique fields of study) were related to humility in the hypothesized direction $(\mathrm{r}=-.154$ and $\mathrm{r}=.124)$. While correlations of .124 and .154 may appear insufficient to consider the indicators to be acceptable proxies for the humility construct, validation studies in the non-executive arena showed similar correlations (using larger samples), and those fairly weak correlations were taken as evidence that the indicators were acceptable proxy variables. For example, Pennebaker and King (1999) found significant correlations 
ranging from .07 and .16 between language use and self-reported personality measures, and they concluded that language use is a meaningful way of exploring personality. While CEO breadth of education and compensation ratio are, at best, imperfect proxies for self-reported humility, the magnitude of the correlations found is similar to other validation studies. It would be interesting to see if these two indicators become significant with a larger validation sample.

Another limitation of this study stands from the nature of the validation sample itself - CEOs of privately-owned companies of diverse sizes and operating in several different industries. Considering secondary data was not available for these CEOs, items were developed to compensate for the lack of publicly-available information. For example, they were asked how "diverse" their top management team was in terms of educational background, which could have been interpreted in different ways by respondents. Such a perceptual measure of TMT diversity might not be a good proxy for the more traditional TMT diversity index, which is based on an objective algorithm (i.e., Blau Index) that uses secondary data on the educational backgrounds of the different TMT members.

The nature of the validation sample was also suboptimal to validate the indicator relative to the $\mathrm{CEO}$ compensation compared to that of the second-highest-paid executive. First, $60 \%$ of our sample were $\mathrm{CEO} /$ founders which may have important compensation implications. In addition, the CEOs operated in very different industries (e.g., IT consulting vs. transportation vs. plumbing). Chatterjee and Hambrick (2007) found a significant positive correlation between CEO compensation compared to the secondhighest-paid executive and narcissism with a sample encompassing CEOs of publicly- 
traded companies exclusively in the computer hardware and software industries. Similarly, when analyzing only highly similar firms in my sample (i.e., 12 IT consulting firms from Canada), I found a correlation of .611 ( $\mathrm{p}<.05)$ between CEO total compensation compared to that of the second-highest-executive and narcissism. The same relationship was not significant when I included all 30 firms. Thus a more homogeneous sample of firms in terms of industries/contexts would have been more adequate to validate the relative compensation indicator.

Lastly, I examined how range restriction and social desirability may have impacted my results. One could argue that humble CEOs are more likely to agree to participate in research studies - suggesting a potential range restriction. When comparing my results to Ou and colleagues (2014), both the mean humility scores and standard deviations (S.D.) are very similar $($ mean $=4.47$ and S.D. $=.5$ for Ou and colleagues versus mean $=4.35$ and S.D. $=.36$ in this study). While my results (both mean and S.D.) are comparable to those of $\mathrm{Ou}$ and colleagues (2014), it does not rule out the possibility that both study samples were biased toward more humble CEOs. If my sample is in fact characterized by a restriction in range, it suggests the results presented here are conservative estimates of the relationships between the proposed unobtrusive indicators and self-reported humility - potentially hindering my ability to detect true effects.

When completing the self-reported measure of humility, CEOs might have been influenced by social desirability. As mentioned previously, the mean for the humility scale was fairly high ( 4.35 for the four dimension scale and 4.5 for the three dimension scale) and the standard deviations were low (.36 for the four dimension scale and .41 for the three dimension scale). However, the narcissism scores - another sensitive trait - 
showed great variability (mean $=.32$ and S.D. $=.19$ ) suggesting the humility scale may need refinement. The development of a self-reported measure of humility based on "forced-choices" as opposed to "likert items" may be a superior alternative to mitigate the threat of social desirability - the use of forced-choice items has been argued to be an effective coping strategy to reduce the threat of social desirability (Nederhof, 1985).

An avenue for future research would be to examine the relationships between the suggested unobtrusive indicators and other-reported measures of CEO humility. Ou (2011) measured humility using both a self-reported measure and other-reported measure (same items) and found weak to moderate correlations between the two on the different dimensions (Self-Awareness $\mathrm{r}=.37, \mathrm{p}<.01$; Appreciation of Others $\mathrm{r}=.34, \mathrm{p}<.01$; Teachability $\mathrm{r}=.32, \mathrm{p}<.01$; Low Self-Focus $\mathrm{r}=.25, \mathrm{p}<.01$ ). Potentially self-reported measures and other-reported measures capture something slightly different and some of the unobtrusive indicators may show higher correlations with other-reported scores.

To conclude, both CEO involvement in non-profits and CEO acknowledgement of the importance of other stakeholders to firm success appear to be significantly related to self-reported humility. Board memberships on non-profits for CEOs of publicly-traded companies can be found online and in different databases, and content analysis of letters to shareholders may be used to assess CEOs acknowledgment of the importance of other stakeholders. While these two indicators represent interesting opportunities for Upper Echelons scholars who are interested in the strategic implications of CEO humility, more validation is needed for the other potential unobtrusive indicators. 


\title{
III. Strategic Implications of CEO Humility
}

\begin{abstract}
Using the unobtrusive indicators of humility described in essay two, this study empirically tested the strategic implications of CEO humility on a set of objective organizational-level outcomes, namely corporate social performance, $R \& D$ spending, firm performance, and firm market valuation. Based on a sample of 163 CEOs appointed to S\&P 500 firms between 2005-2008, results suggested that firms led by humble CEOs tend to outperform others in regards to corporate social performance (KLD strengths), but that their financial performance (ROA) is generally no better or worse. Findings for $R \& D$ spending were mixed - while the individual humility unobtrusive indicators were not significantly related to $R \& D$ spending (with the exception of the CEO's acknowledgement of the importance of other stakeholders to firm success in letters to shareholders), the overall CEO humility index was positively related to $R \& D$ spending. Lastly, results provided preliminary evidence that firms led by humble CEOs tend to be undervalued by the market. The implications of my findings for Upper Echelons theory, and more specifically the influence of CEOs views of self on organizational outcomes are discussed.
\end{abstract}

\section{Introduction}

Over the past several decades, Upper Echelons theorists have examined the impact of top executives' individual differences on different organizational outcomes. Whereas in its early stages, the focus was mainly on observable demographic characteristics, recently work has encompassed a whole host of personality 
characteristics. For example, CEOs personality attributes such as hubris (Hayward, Hambrick, 1997; Li \& Tang, 2010; Tang, Qian, Chen, \& Shen, 2014), core selfevaluations (CSE) (Hiller \& Hambrick, 2005; Resick, Whitman, Weingarden, \& Hiller, 2009; Simsek, Heavey, \& Veiga, 2010), narcissism (Chatterjee \& Hambrick, 2007;

Resick et al., 2009), locus of control (e.g., Miller \& Toulouse, 1986a;

1986b; Sidek \& Zainol, 2011; Van de Ven, Hudson, \& Schroeder, 1984), and the Big 5 (Giberson et al., 2009; Nadkarni \& Herrmann, 2010; Peterson, Smith, Martorana, \& Owens, 2003) were all found to be predictive of different strategic outcomes.

In the past 10 years, the strategic implications of CEOs' views of self has become a prominent topic among Upper Echelons scholars. Several empirical studies have been conducted to examine "how" (and sometimes "when") CEOs self-views impact firms' behaviors and strategies, and how it may, in turn, predict lower or higher performance levels (e.g., Chatterjee \& Hambrick, 2007; Resick et al., 2009, Li \& Tang, 2010). Most research thus far has attempted to answer these questions by focusing on what might be considered the "high" end of the CEO self-concept personality dimensions, namely narcissism, hubris, CSE, and overconfidence.

In this study, I focus on a self-concept personality trait that has received considerably less attention - humility. The dearth of studies on CEO humility is quite surprising considering scholars have recently suggested that due to the complex nature of today's organizations, CEOs must avoid monologues, learn from others, and surround themselves with talented others - all are key components of recent definitions of humility (Drucker, 1992; Ou et al., 2014; Weick, 2001). 
Ou and colleagues (2014) was the first empirical paper to examine humility at the CEO-level. Their study revealed the impact humble CEOs have on team processes (e.g., TMT integration) and employee-level outcomes (e.g., middle managers' work engagement, affective commitment, and job performance). In this essay, I chose to study the impact humble CEOs have on objective organizational outcomes since CEOs are a rare case where an individual's idiosyncrasies shows-up in firm-level outcomes. Thus, this essay represents a first attempt at eliciting the impact humble CEOs have on their organizations (and more objective strategic outcomes). More specifically, I examine the influence of humble CEOs on corporate social responsibility, R\&D spending, firm performance (i.e., ROA), and firm market valuation (i.e., Tobin's Q).

\section{Theoretical Background}

In the last three decades, the Upper Echelons Perspective has been the main theoretical lens used by scholars to understand the influence of executives' personality on organizational outcomes. Originally articulated by Hambrick and Mason (1984), the Upper Echelons Perspective suggests that organizational outcomes (e.g., strategic choices, structure, culture, performance, etc.) can be at least partially predicted by top executives' prior experiences, demographics, values, and personality characteristics. In other words, it proposes that one way to better comprehend organizational strategies is to examine the individual characteristics of the top executives who make strategic decisions on behalf of their firms (Finkelstein, Hambrick, \& Cannella, 2009). On a daily basis, top executives deal with an influx of ambiguous and sometimes contradictory information and the manner in which executives select, comprehend, and interpret this information is 
highly dependent on their prior experiences, values, demographics, and psychological factors (Finkelstein, Hambrick, \& Cannella, 2009). Thus, top executives make decisions based on a highly filtered, personalized, idiosyncratic understanding of the situations they are in, instead of following a perfectly rational algorithm that would weigh all relevant information (Hambrick, 2007; Hambrick \& Mason, 1984). In sum, CEOs' idiosyncrasies influence the way they construe the reality of strategic situations and evaluate different strategic options, and also explain their dispositions toward certain strategic choices (Finkelstein, Hambrick, \& Cannella, 2009).

Although in its original development, the Upper Echelons Perspective referred to the entire top management team (TMT), most of the empirical work on individual differences has been conducted at the CEO-level (Hiller \& Beauchesne, 2014). Strategy scholars have asserted that CEOs in particular greatly influence the strategic direction and performance of their organizations (Hambrick \& Mason, 1984; Peterson et al., 2003). For example, Hambrick (1994) highly criticized studies considering the CEO as just another member of the top management team. He argued that CEOs have a disproportionate and often dominating influence on their firms, thus suggesting that their individual differences can greatly affect the firm's behaviors and performance levels. Consistent with this view, this study focuses on humility at the CEO-level.

\section{CEO Humility and Corporate Social Performance}

Corporate social responsibility (CSR) is defined as a "firm's configuration of principles of social responsibility, processes of social responsiveness, and policies, programs, and observable outcomes as they relate to the firm's societal relationships" 
(Wood, 1991, p.693). In other words, it represents how effectively firms meet the expectations of their different societal stakeholders such as local communities, employees, natural environment, etc. Scholars have devoted a lot of attention to understanding the delicate interplay between CSR and firm performance, and the findings have generally supported a positive association between CSR and firms' long-term financial performance (Berman et al., 1999; Lev, Petrovits, \& Radhakrishnan, 2010; Muller \& Kraussl, 2011; Waddock \& Graves, 1997; Wang \& Qian, 2011).

While there has been considerable empirical research on the firm-level antecedents of poorly and strongly socially performing firms and its consequences on firm performance, we still have a limited knowledge on the influence of top executives' idiosyncrasies on the firm's socially responsible behaviors (Manner, 2010). This is somehow surprising considering corporate leaders have the ultimate say over the strategic approaches firms undertake with respect to corporate social responsibility (Davis, 1973).

Research on how executives influence CSR has focused largely on demographic characteristics, past experiences and compensation (Tang, Qian, Chen, \& Shen, 2014). For instance, using a sample of 650 publicly-traded companies, Manner (2010) found that female CEOs with degrees in humanities and a breadth of career experiences were more likely to encourage CSR initiatives. Based on a sample of 392 CEOs of S\&P 500 companies, Slater and Dixon-Fowler (2009) found CEO international experience to be positively related to corporate social performance (CSP). Researchers have also examined the influence of CEO tenure and compensation on CSR. For example, Deckop, Merriman, and Gupta (2006) found that short-term CEO pay focus was negatively correlated with CSR. Similarly, CEOs approaching retirement (which are also likely to 
have a shorter-term focus) were found to pay less attention to social issues and engaged in less CSR initiatives.

While we have growing evidence that the CEOs' characteristics listed above are predictive of corporate social performance, less is known in regards to the influence CEOs' psychological biases and values have on their firms' engagement toward social issues. Corporate leaders face growing demands to manage both profit and social responsibility (Waddock \& Graves, 1997). How they manage those two, sometimes conflicting, objectives is likely to be indicative of their personality and values (Chin, Hambrick, \& Trevino, 2013). Two recent studies have started investigating this question. First, Chin and colleagues (2013) examined the impact of CEOs' political values (i.e., liberal vs. conservative) on corporate social performance, and found empirical evidence that liberal CEOs emphasize CSR more than conservative CEOs. Second, Tang and colleagues (2014) found that hubristic CEOs (who tend to believe firm success depends more on them than other stakeholders) are less likely to influence their firms toward engaging in socially responsible activities.

Below, I argue CEO humility appears to be an important psychological characteristic to study in the context of CSR. First, humble CEOs' low self-focus leads them to seek the good of the collective above self-interests (Owens, 2009). For publiclytraded firms, the CEOs best interests would be to make strategic decisions which quickly impact their companies' bottom line, making sure board members are satisfied with their work in order to secure their jobs (Erickson \& Jacobson, 1992). Alternatively, CEOs who value collective interests are more likely to engage in strategic actions that benefit all stakeholders. Such types of actions are the heart of what is considered CSR. 
In addition, humble CEOs do not seek immediate personal glory and public attention (Rowatt et al., 2006), which is likely to translate into a longer-term focus. CSR has been found to be positively associated with an array of long-term positive outcomes for firms: superior firm financial performance (Berman et al., 1999; Lev, Petrovits, \& Radhakrishnan, 2010; Muller \& Kraussl, 2011; Waddock \& Graves, 1997; Wang \& Qian, 2011), improved firm reputation (Turban \& Greening, 1996), enhanced firm legitimacy (Handelman \& Arnold, 1999), development of organizational capabilities (Sharma \& Vredenburg, 1998), and improved perception of firm as being ethical (Valentine \& Fleischman, 2008). As such, CSR initiatives are likely to be privileged by CEOs with a longer-term orientation. Characterized as having a longer-term focus, humble CEOs will value strategic initiatives that contribute to the long-term viability of their firms as opposed to short-term, profit-maximizing decisions, which could be detrimental in the long-run.

In sum, considering their stakeholder orientation, and long-term focus, humble CEOs will influence their organizations toward engaging in more socially responsible initiatives. Hence, I anticipate that:

Hypothesis 1: CEO humility will be positively associated with CSP.

\section{CEO Humility and Firm R\&D Spending}

Spending money on research and development (R\&D) is one of the most important strategic decisions firms have to make (Barker \& Mueller, 2002). Considering how central firm R\&D spending is to firms' continuing success, scholars have devoted a lot of attention to understanding its antecedents. Traditional research on the topic has 
mainly focused on firm- and industry-level determinants, often omitting the attributes of top executives as potential antecedents (Barker \& Mueller, 2002). For example, firms' industry (e.g., Sherer, 1984), corporate strategy (e.g., Baysinger \& Hoskisson, 1989; Hoskisson \& Hitt, 1988), board member characteristics (Dalziel, Gentry, \& Bowerman, 2011), and institutional investors (David, Hitt, \& Gimeno, 2001) are some of the numerous factors that have been found to influence firms' R\&D spending.

Most of the existing research on the influence of top executives' individual differences in regards to firms' R\&D spending has focused on CEOs visible characteristics (e.g., demographics, prior experiences, etc.). Barker and Mueller (2002) found that a CEO's age, functional background and stock ownership were predictive of firm R\&D spending even after controlling for traditional firm- and industry-level antecedents. Firms led by CEOs who were younger, had more wealth invested in company stock, and had previous experiences in marketing, $R \& D$ and/or engineering also showed greater R\&D spending. Similarly, Thomas, Litschert, and Ramaswamy (1991) found, using a sample in the computer industry, that firms following market innovation strategies were likely to be led by younger and more educated CEOs. More recently, Lin, Lin, Song and $\mathrm{Li}$ (2011) found that CEOs' educational level, political connections, and performance-driven compensation all predicted greater levels of $R \& D$ spending in the context of manufacturing firms in China.

In addition to observing the impact of CEOs' visible characteristics on firms' $R \& D$ spending, a few studies have looked at CEOs' personality and its relationship with firm innovation (although innovation was not always operationalized as firm R\&D spending). For example, using self-reported surveys, Miller, Kets de Vries and Toulouse 
(1982) found that firms led by CEOs with an internal locus of control engaged in more product-market innovation. More recently, using patent data, Tang, Li and Yang (2012) found that CEO hubris was positively related to firm innovation. The authors argued that hubristic CEOs influence their firms towards engaging in more innovative projects since it is consistent with their self-aggrandizing nature and belief they can achieve miracles.

I argue that CEO humility is another psychological characteristic that is likely to have critical implications in regard to firm R\&D spending. First, firm investment in developing new products, technologies or processes is a key determinant of long-term productivity and competitive advantage (Scherer, 1984; Ettlie, 1998). As such, investing in $\mathrm{R} \& \mathrm{D}$ is considered a long-term strategic investment (Eberhart, Maxwell, \& Siddique, 2004) and it has been found to be predictive of subsequent growth in both sales (Morbey, 1988) and long-term abnormal operating performance (Eberhart et al., 2004). The shortterm focus of some organizations is one reason why some firms do not make the necessary investments in R\&D (Erickson \& Jacobson, 1992). In order to keep their job, CEOs of publicly-traded firms are encouraged to adopt a current-quarter style of management in response to the stock market requirements (Erickson \& Jacobson, 1992). R\&D spending often negatively impacts current quarter earnings (Erickson \& Jacobson, 1992), which may dissuades shorter-term focused CEOs from engaging in such type of investment.

As discussed previously, humble CEOs are not looking for immediate glory or public adulation - allowing them to have a longer-term orientation when deciding what is best for their organizations. Their low self-focus and collective orientation is likely to translate into strategic actions that positively impact the long-term viability of their firms 
in contrast with short-term decisions that would bring them into the spotlight and ensure their job, but potentially be detrimental to their organizations' continuing success. In addition, humble CEOs are also characterized by an openness to learn which translates into an openness to new ideas, feedback and information (Owens, 2009; Tangney, 2000). Investing in R\&D clearly demonstrates an organization's desire to constantly learn and improve its processes and products. I argue humble CEOs will prioritize such investments since it is consistent with their personal preference for continual development and improvement. In sum, considering their long-term orientation and openness to new ideas, combined with their preference for continual improvement and learning, humble CEOs should influence their firms toward greater R\&D spending. Hence, I anticipate that:

Hypothesis 2: CEO humility will be positively associated with firm $R \& D$ spending.

\section{CEO Humility and Firm Performance}

Firm performance represents a broad category of organizational outcomes, which has received considerable attention in the Upper Echelons literature. Scholars have studied the impact of CEOs' individual differences both directly with organizational performance and through mediating mechanisms such as company strategy, structure, etc (Hiller \& Beauchesne, 2014). Considering how distal firm performance is from CEOs' individual differences, it has been argued that CEOs' characteristics better predict more proximal outcomes such as firms' strategies and culture (Finkelstein et al., 2009).

While Upper Echelons studies have largely focused on more proximal outcomes, a review of the literature shows that a number of studies found significant relationships 
between CEOs' characteristics and firm performance measures (Hiller, Beauchesne, \& Whitman, 2013). For example, using a sample of Fortune 500 companies, CEO narcissism was found to be positively associated with Earnings-Per-Share (Olsen, Dworkis, \& Young, 2013). They argued that this relationship may be due to the fact that the qualities associated with narcissistic tendencies led to better performance by CEOs and/or that more narcissistic CEOs took advantage of the subjectivity and ambiguity in financial accounting to paint a rosier picture of their financial performance - which allowed them to receive attention and praise. Chatterjee \& Hambrick (2007) also studied the impact of narcissistic CEOs on firm performance. While they did not find CEO narcissism to be predictive of firm performance average, it was found to predict fluctuations in performance - firms led by narcissistic CEOs showed more extreme performance levels (ROA and TSR). In another study, CEO tenure was found to positively predict firm performance (i.e., ROA, ROIC, and ROS) in stable industries, whereas it was negatively related to performance in more dynamic industries (Henderson, Miller, \& Hambrick, 2006). They argued that in dynamic industries, CEOs' paradigms grow obsolete faster than they could learn which led to lower performance for longertenured CEOs.

In a recent meta-analysis, Hiller, Beauchesne and Whitman (2013) found significant positive true score correlations between accounting measures of performance and CEO openness $(\rho=.30)$, CEO CSE $(\rho=.18)$, and CEO internal locus of control $(\rho=.23)$. Although these results need to be interpreted carefully considering the small number of studies included in the analyses, it does suggest that CEO characteristics may have a sizeable impact on distal outcomes such as accounting measures of performance. 
In this section, I argue that CEO humility is another personality characteristic that may have important implications for firm performance. Due to both their accurate selfassessment of personal strengths and weaknesses and their appreciation for others' talents, humble CEOs are more likely to surround themselves with complimentary and highly successful executives (Tjan, 2012). Ancona, Malone, Orlikowski, and Senge (2007) suggested that only leaders who are aware of both their strengths and weaknesses (i.e., aware of their own limitations) would be able to counterbalance their missing skills by relying on others. Humble CEOs' open attitude to others' ideas will encourage dialogues among TMT members to reach successful decisions. For example, Ou and colleagues (2014) found that CEO humility was positively related to TMT integration the level of collaborative behavior, the quantity and quality of information exchanged, and the emphasis on joint decision-making within the TMT (Hambrick, 1994). In a different study, Carmeli (2008) found that TMT integration was positively associated with a perceptual measure of firm economic performance. The capacity of humble CEOs to listen and learn from others is key to leading large complex organizations, since one individual cannot possess all the resources needed to make every decision in such context (Ireland \& Hitt, 1999).

Humble CEOs are also characterized by their openness to learn which is critical to successful leadership in an increasingly complex and interconnected business environment (Ou, 2011). One of the most often cited functions of CEOs is their boundary spanning responsibility (Jacobs \& Jaques, 1987; Katz \& Kahn, 1978). In order to ensure a constant adaptation of their organizations with the broader environment (i.e., boundary spanning), CEOs must be willing and capable to learn and adapt to varying situations. 
Humble CEOs who are described as open to new ideas, ways of doing things and feedback (Owens, 2009) are likely to be successful when operating in changing environments.

Humble individuals are also characterized as having a low self-focus. Thus, humble CEOs will keep in mind the best interests of the organization they lead and the larger community as opposed to pursuing self-interested motives (Owens, 2009). They will pursue strategies that best fit their organizations' needs, regardless of the immediate impact on their popularity. As argued previously, if it is not in the long-term best interests of their company, humble CEOs will not make grandiose risky decisions to get the attention and admiration of the public. In light of all the aforementioned arguments, I forsee that firms led by humble CEOs will generally outperform those led by less humble CEOs. Hence, I anticipate that:

Hypothesis 3: CEO humility will be positively associated with firm performance.

\section{CEO Humility and Firm Market Valuation}

Tobin's Q, a financial, market-based measure of performance, is defined as the ratio of the market value of a firm to the replacement cost of its assets (Lindberg \& Ross, 1981). A Tobin's Q value above one, means that the firm has a market value that is greater than the value of the company's recorded assets. Ratios above one are interpreted as a sign of unmeasured source of value, which is generally attributed to intangible value possessed by the firm (Bharadwaj, Bharadwaj, \& Konsynski, 1999). Alternatively, Qratio below one suggests the market is undervaluing the company. 
The value added by the top management of an organization is considered an important intangible asset captured by Tobin's Q (Huselid, Jackson, \& Schuler, 1997). Considering CEOs are the most visible and scrutinized human resource a firm has, their behaviors are likely to impact how their firms are perceived and consequently, valued by the market. I argue that CEO humility is an important characteristic to study in regard to firms' market valuation. Humble CEOs, characterized as having a low self-focus (Ou et al., 2014; Owens, 2009; Tangney, 2002), are less likely to be highly visible in the media, which may in turn contribute to building less publicity for their companies. In addition, as argued previously, humble CEOs are more likely to have a stakeholder orientation - they are interested in the long-term viability of their firm and creating value for all stakeholders, not only pleasing shareholders. In sum, considering humble CEOs are less likely to be out in the media boasting the success of their organizations, and following the argument that they have more of a stakeholder orientation, I expect that firms led by humble CEOs will have lower Tobin's Q ratio. Hence, I anticipate that:

Hypothesis 4: CEO humility will be negatively associated with a firm's market valuation

\section{Methodology}

\section{Sample}

The different hypotheses were tested using a sample of U.S. CEOs appointed to S\&P 500 firms between 2005-2008. S\&P 500 firms represent a wide array of industries, thus I expect findings to show a high degree of external validity. CEOs appointed to S\&P 500 firms during that time period were initially identified, but only those with at least three years of tenure within the study period were included. CEOs with less than three 
years of tenure were eliminated considering the humility indicators were measured on the second and third year of CEO tenure. The search generated a total of 163 CEOs (all from different firms).

CEO humility indicators were measured on the second and third year of CEO tenure (i.e., average of the two years). The first year was eliminated due to potential anomalies resulting from the succession event (Chatterjee \& Hambrick, 2007). Consistent with the stable nature of personality, CEO humility scores on the different indicators were invariant (i.e., based on humility scores measured on years two and three). Alternatively, the dependent variables (i.e., CSP, R\&D spending, ROA, and Tobin's Q) were measured each year starting on the second year of the CEO's tenure. Data for R\&D spending, ROA, and Tobin's Q were collected up to 2013. While data on CSR was only available to the author until 2009, resulting in a smaller dataset to test the CSR hypothesis. As a result, empirical analyses were conducted using a firm-year structure.

\section{Independent Variables}

The unobtrusive humility indicators described in essay two were used for the different analyses. In the first set of analyses, humility indicators were entered individually in the different regressions. Considering some of the proposed humility indicators overlap conceptually, and in order to minimize multicollinearity, six indicators were selected: CEOs' board membership on non-profits, CEOs' breadth of studies, TMT educational diversity, $\mathrm{CEO}$ compensation ratios (cash and non-cash), and CEOs' acknowledgement of the importance of other stakeholders in the letters to shareholders. These six indicators were chosen since they conceptually best capture the four 
dimensions of humility: teachability/openness to learn (CEOs' breadth of studies), selfawareness (TMT educational diversity), appreciation of others' strengths (CEOs' acknowledgement of the importance of other stakeholders), and low self-focus (CEO compensation ratio and CEOs' board membership on non-profits).

The other proposed indicators (i.e., CEO career variety, CEO educational level, size of the CEO picture in annual reports, and functional diversity) were not included in the regressions. CEO educational level was excluded since it was found to be highly correlated with CEOs' breadth of studies ( $\mathrm{r}=.64)$. Similarly, TMT functional diversity was not included since it was correlated with TMT educational diversity $(\mathrm{r}=.38)$, and both variables greatly overlap conceptually. Used previously as a proxy for narcissism, the size of CEOs' photographs in annual reports was excluded given that the low self-focus component of humility was already captured by CEOs' compensation ratio (also used previously as a measure of narcissism). Lastly, CEO career variety was excluded as a variable because essay two suggests that it is a better indicator of openness to experience.

For the second set of regressions, a humility index was created based on the same unobtrusive indicators: breadth of education, board membership on non-profits, TMT educational diversity, CEO relative compensation, and acknowledgement of the work of others in letters to shareholders. The index was calculated as the simple mean of the different measures, after standardization, for each CEO. As a test of coherence among the different indicators, I performed a confirmatory factor analysis (CFA) (see Figure 9). The CFA showed weak standardized coefficients and the model goodness of fit indices were below acceptance levels $(\mathrm{CFI}=.683$ and RMSEA $=.084)($ Browne \& Cudeck, 1993; Hu \& Bentler, 1998). In addition, I calculated the Cronbach alpha for the standardized values of 
all five variables. The alpha was .16, which is considerably below the threshold (.70) to form a new reflective index (Nunnally, 1978). The weak correlations among the different proposed humility unobtrusive indicators may be partly explained by the multi-faceted nature of the humility construct, that suggests it is best represented as a formative construct - the proposed indicators potentially capturing the different sub-dimensions of humility. Using the formative approach, indicators can be combined to form a new construct without any assumptions as to the patterns of inter-correlations among them (Diamantopoulos \& Winklhofer, 2001). In this case, each unobtrusive indicator may be capturing a slightly different conceptual domain of the overarching humility construct. 
Figure 9: Confirmatory Factor Analysis - Unobtrusive Indicators

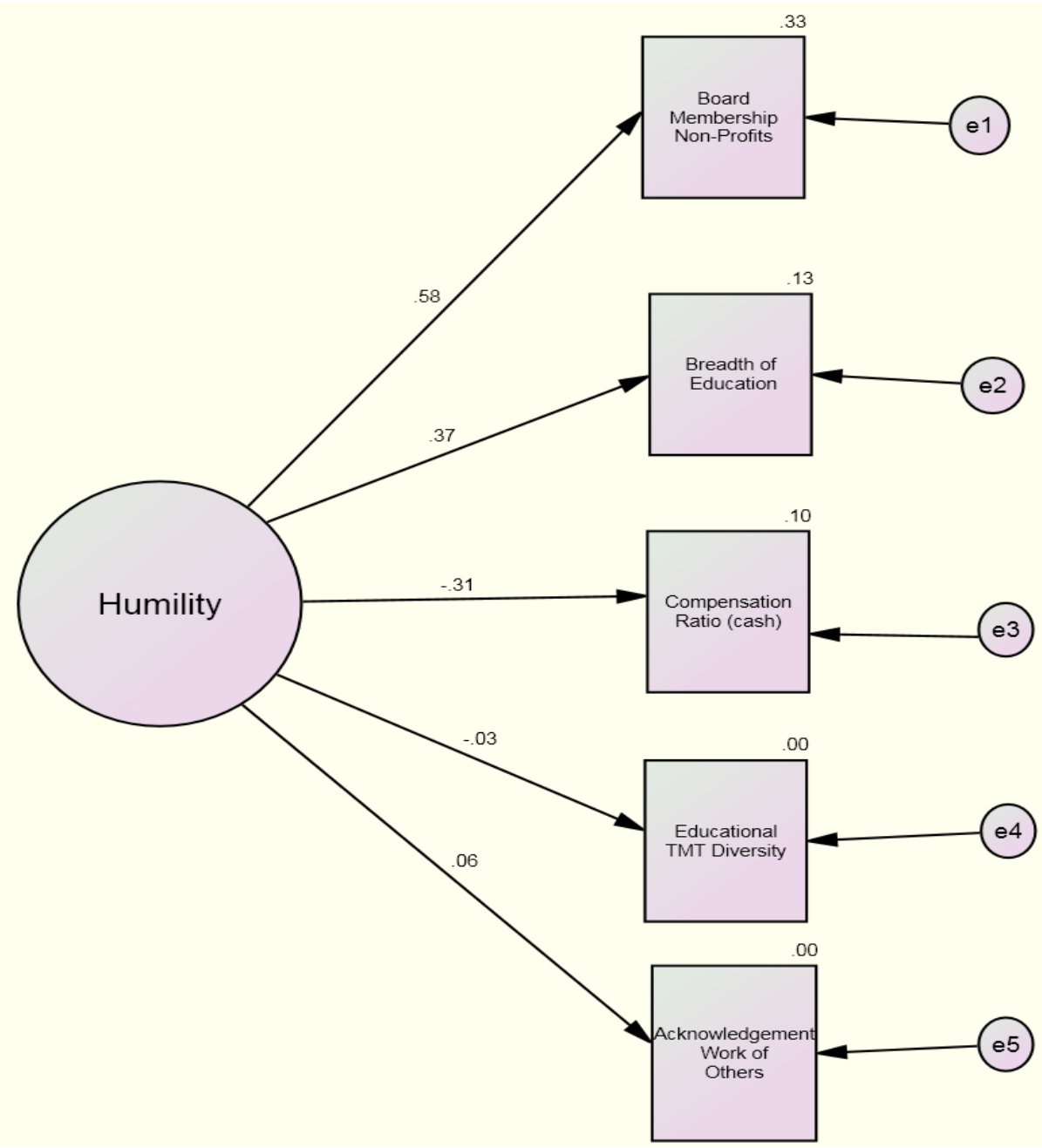

\section{Dependent Variables}

The corporate social performance measure included KLD Research \& Analytics, Inc. (KLD) ratings on five dimensions: community, diversity, employee relations, environmental impact, and product safety and quality. These dimensions were chosen since they best represent the stakeholder orientation of CSP (Agle, Mitchell, \& Sonnenfeld, 1999). Prior work has suggested corporate leaders' beliefs impact strong (i.e., proactive) CSP more than avoidance of poor CSP (Manner, 2010). Thus, CSP was operationalized as a firm's total number of strengths on the five dimensions. $R \& D$ 
spending was operationalized as the total dollars spent in R\&D divided by the total number of employees (Barker \& Mueller, 2002; Baysinger et al., 1991; Hill \& Snell, 1989; Scherer, 1984). Firm performance was operationalized using return on assets (ROA), calculated as the net income divided by assets (minus the industry median ROA based on 2-digit SIC codes) (Chatterjee \& Hambrick, 2007). Lastly, firm market valuation was operationalized using Tobin's Q (Chung \& Pruitt, 1994) - Tobin's Q represents a firm's total market value divided by its total asset value. I subtracted the industry median Tobin's Q from each firm/year Tobin's Q ratio (based on 2-digit SIC codes). Industry ROA and Tobin's Q medians were preferred to means since they are much less affected by outliers. In addition, for all dependent variables, outliers (i.e., all measures with standardized values greater than 3.29) were excluded from the different analyses.

\section{Control Variables}

Control variables at the CEO-, firm-, and industry- levels were included in the different regression models. Firm size, operationalized as the total number of employees, was included in all models. Prior year performance, operationalized as a firm prior year ROA, was also included in the analyses. Industry dummies were created based on the first two digits of the Global Industry Classification Standard (GICS). Industry dummies were only included in the CSR and R\&D spending regressions considering both the ROA and Tobin's Q dependent variables were already adjusted for industry effects. CEO age was controlled for in the different R\&D, ROA, and Tobin's Q regression models.

Previous studies have found CEO age to be related to lower levels of innovation (e.g., 
Barker \& Mueller, 2002; Thomas et al., 1991), and CEO age is traditionally included in models predicting firm performance (e.g., Chatterjee \& Hambrick, 2007; Olsen et al., 2013). CEO tenure was omitted in final regressions since it was not significant in any of the models.

\section{Data Sources}

Humility indicators were coded based on information contained in varied sources: company's annual reports, COMPUSTAT, Bloomberg database, and executive profiles (Forbes and Bloomberg Businessweek). Consistent with recent empirical work (Agle et al., 1999; Bernan et al., 1999; Coombs \& Gilley, 2005; Graves \& Waddock, 1994; Manner, 2010; McWilliams \& Siegel, 2000; Slater \& Dixon-Fowler, 2009), CSR data was collected from the KLD database. R\&D spending, ROA, Tobin's Q, and the control variables were obtained via COMPUSTAT.

\section{Statistical Analyses}

Considering the nature of the dataset (i.e., multiple observations for all firms in the sample), generalized estimating equations (GEE) were used. GEE derive maximum likelihood estimates and take into account the use of non-independent observations (Chatterjee \& Hambrick, 2007). For the CSR analyses, since my dependent variable is a count variable (i.e., total strengths), a Poisson distribution was used. For the analyses relative to R\&D spending, ROA and Tobins' Q (which are all continuous variables), normal distributions were used. 


\section{Results}

Table 3 presents the means, standard deviations, and correlations among the variables in the study. Table 4 shows the GEE results for the effects of the different humility indicators on CSP. For each dependant variable, two models are presented: the first model exclusively includes the control variables, whereas the full model adds the main effects (i.e., the CEO unobtrusive humility indicators). Hypothesis 1 suggested CEO humility would be positively associated to firm social performance, four out of the six proposed humility indicators were related to CSP in the hypothesized direction (i.e., CEO board membership on non-profits, $\mathrm{p}<.10$; CEO breadth of education, $\mathrm{p}<.05$, TMT educational diversity, $\mathrm{p}<.01$; CEO non-cash pay ratio, $\mathrm{p}<.05$ ), providing preliminary support for hypothesis 1 . In addition, after controlling for firm size and prior year ROA, Table 8 shows that the overall CEO humility index is positively related to $\operatorname{CSP}(\mathrm{p}<.05)$, adding additional support to hypothesis 1 .

Table 5 shows the GEE results for the test of the relationship between the CEO humility indicators and firm R\&D spending. Hypothesis 2 suggested CEO humility would be positively related to firm R\&D spending. Only one indicator out of the six (i.e., CEOs' acknowledgement of the importance of other stakeholders to firm success in letters to shareholders, $\mathrm{p}<.10$ ) was related to firm $\mathrm{R} \& \mathrm{D}$ spending in the hypothesized direction, providing minimal support for hypothesis 2 . However, Table 8 shows that the overall CEO humility index is related to firm R\&D spending in the hypothesized direction $(\mathrm{p}<.05)$, providing some support for hypothesis 2 . Additional research is needed to untangle the mixed findings. 
Table 6 shows the GEE results for the test of the relationship between the CEO humility indicators and firm performance (operationalized as ROA). Hypothesis 3 suggested CEO humility would be positively related to firm performance. Of the proposed humility indicators, none were found to be related to ROA in the hypothesized direction, providing no support for hypothesis 3. Similar results were found using the CEO humility index (Table 8).

Lastly, Table 7 presents the results for the impact of CEO humility on firm market valuation. Hypothesis 4 suggested CEO humility would be negatively related to firm market valuation. Three out of the six indicators entered in the regression were found to be significant (i.e., CEO breadth of education, $\mathrm{p}<.05$; CEO non-cash pay ratio, $\mathrm{p}<.01$; CEOs' acknowledgement of the importance of other stakeholders to firm success in letters to shareholders, $\mathrm{p}<.05$ ). In addition, Table 8 shows that the CEO humility index is significantly related to firm market valuation in the hypothesized direction $(\mathrm{p}<.05)$, providing additional support for hypothesis 4 . 
Table 3: Main Study Descriptive Statistics and Correlations

\begin{tabular}{|c|c|c|c|c|c|c|c|c|c|c|c|c|c|c|c|}
\hline Variables & Mean & S.D. & 1 & 2 & 3 & 4 & 5 & 6 & 7 & 8 & 9 & 10 & 11 & 12 & 13 \\
\hline 1. Humility Index & .004 & .482 & 1 & & & & & & & & & & & & \\
\hline 2. CEO Board - Non Profit & .459 & .499 & $.613^{* *}$ & 1 & & & & & & & & & & & \\
\hline 3. CEO Breadth of Education & 1.343 & .600 & $.502^{* *}$ & $.206^{* *}$ & 1 & & & & & & & & & & \\
\hline 4. CEO Career Variety & .228 & .100 & $.067^{*}$ & $-.139^{* *}$ & $.105^{* *}$ & 1 & & & & & & & & & \\
\hline 5. CEO Cash Pay Ratio & 1.633 & .552 & $-.243^{* *}$ & $-.144^{* *}$ & $-.099^{* *}$ & .018 & 1 & & & & & & & & \\
\hline 6. CEO Non-Cash Pay Ratio & 2.075 & 1.651 & .046 & -.061 & .055 & $.196^{* *}$ & $.259^{* *}$ & 1 & & & & & & & \\
\hline $\begin{array}{l}\text { 7. CEO Importance Other } \\
\text { Stakeholders (ordinal) }\end{array}$ & 1.561 & .539 & $.449^{* *}$ & $.088^{* *}$ & -.028 & $.269^{* *}$ & -.008 & .007 & 1 & & & & & & \\
\hline 8. CEO Education Level & 4.665 & .882 & $.335^{* *}$ & $.164^{* *}$ & $.636^{* *}$ & $.256^{* *}$ & -.045 & $.164^{* *}$ & .047 & 1 & & & & & \\
\hline 9. CEO Photograph Size & 2.543 & .897 & -.066 & $-.078^{*}$ & $-.096^{* *}$ & .004 & $-.178^{* *}$ & -.009 & -.039 & $-.145^{* *}$ & 1 & & & & \\
\hline 10. TMT Educational Diversity & .504 & .160 & $.404^{* *}$ & .034 & .008 & -.014 & $.149^{* *}$ & $.160^{* *}$ & .003 & .000 & -.048 & 1 & & & \\
\hline 11. TMT Functional Diversity & .724 & .093 & $.087^{* *}$ & -.004 & $.099^{* *}$ & .045 & $.162^{* *}$ & $.170^{* *}$ & $-.113^{* *}$ & $.073^{*}$ & $-.150^{* *}$ & $.382^{* *}$ & 1 & & \\
\hline 12. CSR Strengths & 3.537 & 3.468 & $.146^{* *}$ & $.128^{* *}$ & $.169^{* *}$ & -.040 & $.114^{*}$ & -.085 & -.080 & $.144^{* *}$ & -.022 & $.188^{* *}$ & $.171^{* *}$ & 1 & \\
\hline 13. CSR Concerns & 2.986 & 2.526 & $268^{* *}$ & $.193^{* *}$ & $.178^{* *}$ & -.061 & $.099^{*}$ & -.035 & $.133^{* *}$ & $.171^{* *}$ & $-.241^{* *}$ & $.129^{* *}$ & .011 & $.364^{* *}$ & 1 \\
\hline 14. CSR Overall & .551 & 3.467 & -.049 & -.012 & .040 & .005 & .041 & -.059 & $-.178^{* *}$ & .019 & $.153^{* *}$ & .095 & $.164^{* *}$ & $.735^{* *}$ & $-.364^{* *}$ \\
\hline 15. R\&D Spending & 24.407 & 39.629 & $.105^{*}$ & $-.131^{* *}$ & .065 & $.153^{* *}$ & $-.100^{*}$ & .021 & -.014 & $.107^{*}$ & .084 & $.181^{* *}$ & $.245^{* *}$ & $.274^{* *}$ & -.075 \\
\hline 16. ROA & .067 & .058 & $-.131^{* *}$ & $-.175^{* *}$ & $-.120^{* *}$ & .013 & .022 & -.043 & .009 & -.032 & -.017 & $.074^{*}$ & .061 & .049 & $-.122^{*}$ \\
\hline 17. ROE & .058 & .060 & .065 & -.018 & -.009 & $-.093^{* *}$ & .056 & .002 & .050 & -.020 & $-.105^{* *}$ & $.151^{* *}$ & .008 & .037 & .036 \\
\hline 18. Tobin's Q & 1.854 & .850 & $-.155^{* *}$ & $-.106^{* *}$ & $-.180^{* *}$ & $.093^{* *}$ & $-.095^{* *}$ & $-.093^{* *}$ & $-.072^{*}$ & $-.085^{*}$ & .042 & -.010 & $.127^{* *}$ & .040 & $-.259^{* *}$ \\
\hline 19. EPS & 2.776 & 3.444 & .063 & .058 & -.017 & -.011 & -.037 & -.065 & $.092^{* *}$ & $.076^{*}$ & $-.098^{* *}$ & .007 & -.012 & .051 & .073 \\
\hline 20. Firm Size (thousands employees) & 49.044 & 70.204 & .035 & $.141^{* *}$ & -.009 & .045 & $.096^{* *}$ & -.034 & .027 & -.018 & -.049 & -.043 & $.079^{*}$ & $.476^{* *}$ & $.379^{* *}$ \\
\hline 21. Prior Year ROA & .065 & .084 & $-.090^{* *}$ & $-.099^{* *}$ & $-.066^{*}$ & -.011 & -.054 & -.064 & -.017 & -.015 & -.003 & .048 & .051 & .060 & -.075 \\
\hline 22. CEO Age & 55.441 & 5.529 & $.156^{* *}$ & $.192^{* *}$ & $.088^{* *}$ & $-.591^{* *}$ & -.008 & $-.071^{*}$ & $-.106^{* *}$ & $.074^{*}$ & -.050 & $.151^{* *}$ & .032 & $.147^{* *}$ & $.277^{* *}$ \\
\hline 23. CEO Tenure & 3.668 & 2.021 & -.012 & -.018 & .014 & .054 & .008 & .011 & .022 & -.004 & .033 & -.011 & -.007 & -.003 & .045 \\
\hline
\end{tabular}


Table 3: Main Study Descriptive Statistics and Correlations (cont.)

\begin{tabular}{|c|c|c|c|c|c|c|c|c|c|c|}
\hline Variables & 14 & 15 & 16 & 17 & 18 & 19 & 20 & 21 & 22 & 23 \\
\hline 14. CSR Overall & 1 & & & & & & & & & \\
\hline 15. R\&D Spending & $.330^{* *}$ & 1 & & & & & & & & \\
\hline 16. ROA & $.140^{* *}$ & .036 & 1 & & & & & & & \\
\hline 17. ROE & .011 & $-.154^{* *}$ & $.471^{* *}$ & 1 & & & & & & \\
\hline 18. Tobin's Q & $.226^{* *}$ & $.178^{* *}$ & $.703^{* *}$ & -.044 & 1 & & & & & \\
\hline 19. EPS & -.002 & $-.197^{* *}$ & $.372^{* *}$ & $.490^{* *}$ & $.164^{* *}$ & 1 & & & & \\
\hline 20. Firm Size (thousands employees) & $.202^{* *}$ & $-.225^{* *}$ & .026 & .051 & .014 & .046 & 1 & & & \\
\hline 21. Prior Year ROA & $.115^{*}$ & -.031 & $.591^{* *}$ & $.177^{* *}$ & $.477^{* *}$ & $.146^{* *}$ & .017 & 1 & & \\
\hline 22. CEO Age & -.055 & $-.138^{* *}$ & -.059 & .034 & $-.135^{* *}$ & -.026 & .022 & -.045 & 1 & \\
\hline 23. CEO Tenure & -.035 & .061 & -.008 & .048 & -.022 & $.126^{* *}$ & $.072^{*}$ & -.010 & $-.150^{* *}$ & 1 \\
\hline
\end{tabular}

Note: $(*)$ less than $0.05 ;(* *)$ less than 0.01 (two-tailed) 
Table 4: Results of GEE Analysis of CEO Humility Unobtrusive Indicators and CSP

\begin{tabular}{|c|c|c|c|c|}
\hline \multirow[t]{2}{*}{ Variables } & \multicolumn{2}{|c|}{$\begin{array}{c}\text { Model } 1 \\
\text { Control Model }\end{array}$} & \multicolumn{2}{|c|}{$\begin{array}{c}\text { Model } 2 \\
\text { Full Model }\end{array}$} \\
\hline & .166 & $(.28)$ & .109 & $(.35)$ \\
\hline Industry 2 & .335 & $(.21)$ & .207 & $(.26)$ \\
\hline Industry 3 & $.477 f$ & $(.25)$ & .282 & (.29) \\
\hline Industry 4 & $.640^{*}$ & $(.28)$ & .192 & $(.31)$ \\
\hline Industry 5 & .122 & $(.24)$ & -.020 & $(.28)$ \\
\hline Industry6 & .088 & $(.29)$ & -.070 & $(.28)$ \\
\hline Industry 7 & $.450^{*}$ & (.19) & .064 & $(.25)$ \\
\hline Industry 8 & .046 & $(.24)$ & -.229 & $(.31)$ \\
\hline Industry 9 & $.923 * *$ & $(.27)$ & .339 & $(.38)$ \\
\hline Firm Size (employees) & $.006^{* *}$ & $(.00)$ & $.005 * *$ & $(.00)$ \\
\hline Prior Yr ROA & .599 & $(.75)$ & .881 & (.63) \\
\hline CEO Board-Non-Profit & & & $.254 \mathrm{f}$ & $(.15)$ \\
\hline CEO Breadth of Education & & & $.273 *$ & $(.14)$ \\
\hline TMT (Education) Diversity & & & $1.484^{* *}$ & $(.46)$ \\
\hline CEO Cash Pay Ratio & & & $.224 *$ & $(.12)$ \\
\hline CEO Non-Cash Pay Ratio & & & $-.071 *$ & $(.04)$ \\
\hline CEO Importance Other Stakeholders (ordinal) & & & -.107 & $(.16)$ \\
\hline QICC & & & & \\
\hline
\end{tabular}

(f) Indicates a significance level of less than $0.1 ;\left(^{*}\right)$ less than $0.05 ;\left(^{* *}\right)$ less than $0.01, \mathrm{~N}=367$ firm/yrs

Table 5: Results of GEE Analysis of CEO Humility Unobtrusive Indicators and R\&D Spending

\begin{tabular}{|c|c|c|c|c|}
\hline \multirow[t]{2}{*}{ Variables } & \multicolumn{2}{|c|}{$\begin{array}{c}\text { Model 1 } \\
\text { Control Model }\end{array}$} & \multicolumn{2}{|c|}{$\begin{array}{c}\text { Model 2 } \\
\text { Full Model }\end{array}$} \\
\hline & 5.906 & $(8.66)$ & 15.733 & $(10.38)$ \\
\hline Industry 2 & 9.820 & $(8.27)$ & 14.672 & $(11.31)$ \\
\hline Industry 3 & 6.513 & $(8.33)$ & 10.33 & $(10.57)$ \\
\hline Industry 4 & 2.939 & $(4.95)$ & 7.584 & $(9.62)$ \\
\hline Industry 5 & 9.193 & (7.13) & $20.210 \dagger$ & $(11.79)$ \\
\hline Industry6 & -18.160 & $(12.24)$ & -15.815 & $(14.17)$ \\
\hline Industry 7 & $15.591^{*}$ & (7.74) & 11.054 & $(10.37)$ \\
\hline Industry 8 & $-42.269 * *$ & $(14.68)$ & -45.230 & $(14.25)$ \\
\hline Firm Size (employees) & $-.049 f$ & $(.03)$ & $-.049 f$ & $(.03)$ \\
\hline Prior Yr ROA & -8.078 & $(45.14)$ & -5295 & $(48.43)$ \\
\hline CEO Age & -.005 & (.63) & -.091 & $(.69)$ \\
\hline CEO Board - Non-Profit & & & 5.623 & $(6.38)$ \\
\hline CEO Breadth of Education & & & 4.483 & 6.69 \\
\hline TMT (Education) Diversity & & & 35.167 & $(28.02)$ \\
\hline CEO Cash Pay Ratio & & & 4.332 & $(6.42)$ \\
\hline CEO Non-Cash Pay Ratio & & & .185 & (1.64) \\
\hline CEO Importance Other Stakeholders (ordinal) & & & 11.715 † & $(6.15)$ \\
\hline QICC & 3959 & & & \\
\hline
\end{tabular}

(f) Indicates a significance level of less than $0.1 ;\left(^{*}\right)$ less than $0.05 ;\left(^{* *}\right)$ less than $0.01, \mathrm{~N}=436$ firm/yrs 
Table 6: Results of GEE Analysis of CEO Humility Unobtrusive Indicators and ROA

\begin{tabular}{|c|c|c|c|c|}
\hline \multirow[b]{3}{*}{ Firm Size (employees) } & \multicolumn{2}{|c|}{ Model 1} & \multicolumn{2}{|c|}{ Model 2} \\
\hline & \multicolumn{2}{|c|}{ Control Model } & \multicolumn{2}{|c|}{ Full Model } \\
\hline & $.000 * *$ & $(.00)$ & $.000 * *$ & $(.00)$ \\
\hline Prior Yr ROA & $.573 * *$ & $(1.56)$ & $.560 * *$ & $(.11)$ \\
\hline CEO Age & .001 & $(.00)$ & .001 & $(.00)$ \\
\hline CEO Board - Non-Profit & & & -.019 & $(.01)$ \\
\hline CEO Breadth of Education & & & .005 & $(.01)$ \\
\hline TMT (Education) Diversity & & & .008 & $(.04)$ \\
\hline CEO Cash Pay Ratio & & & .008 & $(.01)$ \\
\hline CEO Non-Cash Pay Ratio & & & $.000^{*}$ & $(.00)$ \\
\hline CEO Importance Other Stakeholders (ordinal) & & & .004 & $(.01)$ \\
\hline QICC & & & & \\
\hline
\end{tabular}

Table 7: Results of GEE Analysis of CEO Humility Index and Tobin's Q (adjusted)

\begin{tabular}{lcccc}
\hline \multicolumn{1}{c}{ Variables } & Model 1 & \multicolumn{2}{c}{ Model 2 } \\
& Control Model & Full Model \\
Firm Size (employees) & .000 & $(.00)$ & .000 & $(.00)$ \\
Prior Yr ROA & $5.787^{* *}$ & $(1.56)$ & $5.606^{* *}$ \\
CEO Age & $-.019^{*}$ & $(.01)$ & $-.017 \dagger$ \\
CEO Board - Non-Profit & & -.074 \\
CEO Breadth of Education & & $-.175^{*}$ \\
TMT (Education) Diversity & & -.173 \\
CEO Cash Pay Ratio & & -.071 \\
CEO Non-Cash Pay Ratio & & $.028^{* *}$ \\
CEO Importance Other Stakeholders (ordinal) & & \\
\hline
\end{tabular}


Table 8: Results of GEE Analysis of CEO Humility Index and DVs

\begin{tabular}{|c|c|c|c|c|c|c|c|c|}
\hline \multirow{2}{*}{$\begin{array}{l}\text { Variables } \\
\text { Industry } 1\end{array}$} & \multicolumn{2}{|c|}{ CSR } & \multicolumn{2}{|c|}{ R\&D Spending } & \multicolumn{2}{|c|}{ ROA } & \multicolumn{2}{|c|}{ Tobin's Q } \\
\hline & .174 & $(.29)$ & 15.045 & $(9.61)$ & & & & \\
\hline Industry 2 & .246 & $(.22)$ & $14.476 \dagger$ & $(8.79)$ & & & & \\
\hline Industry 3 & .394 & $(.26)$ & 8.336 & $(6.73)$ & & & & \\
\hline Industry 4 & $.533 f$ & $(.29)$ & 4.823 & $(5.35)$ & & & & \\
\hline Industry 5 & .095 & $(.25)$ & $18.466^{*}$ & $(8.31)$ & & & & \\
\hline Industry 6 & .036 & $(.28)$ & -12.699 & (11.39) & & & & \\
\hline Industry 7 & $.434 *$ & $(.22)$ & $16.132 *$ & $(7.63)$ & & & & \\
\hline Industry 8 & -.109 & $(.27)$ & $-42.13 * *$ & (13.12) & & & & \\
\hline Industry 9 & $.790 * *$ & $(.28)$ & & & & & & \\
\hline Firm Size (employees) & $.005 * *$ & $(.00)$ & $-.065^{*}$ & $(.03)$ & $.000 * *$ & $(.00)$ & .000 & $(.00)$ \\
\hline Prior Yr ROA & .677 & $(.78)$ & -10.536 & $(46.50)$ & $.567 * *$ & $(.08)$ & $5.788^{* *}$ & $(1.54)$ \\
\hline CEO Humility Index & $.244^{*}$ & (.11) & $19.100 *$ & $(9.03)$ & -.007 & (.01) & $-.329 *$ & (.13) \\
\hline QICC & & & 3721 & .215 & & & 526 & \\
\hline
\end{tabular}

(f) Indicates a significance level of less than $0.1 ;\left(^{*}\right)$ less than $0.05 ;\left(^{* *}\right)$ less than 0.01

\section{Discussion and Conclusion}

Research on the strategic implications of CEOs' views of self has received a lot of attention in the Upper Echelons literature in the past 10 years. However, this literature has disproportionally focused on the "high" end of the self-concept spectrum: narcissism, CSE, overconfidence, and hubris. CEOs who think extremely highly of themselves were found to engage in riskier strategies (Chatterjee \& Hambrick, 2007, 2011), lead their firms to experience more performance fluctuations (Chatterjee \& Hambrick, 2007), pay higher premiums for acquisitions (Hayward \& Hambrick, 1997), and show greater Earnings-Per-Share (Olsen et al., 2013). This study adds to this body of literature by examining the strategic implications of a different category of CEOs, the humble CEOs, 
who are characterized as having a balanced view of self, a developmental orientation, a low self-focus, and an appreciation of others' contributions (Owens, 2009).

Using a longitudinal dataset of S\&P 500 companies, I found evidence that humble CEOs led firms to engage in more socially responsible initiatives. These findings provide empirical support to Ou and colleagues' (2014) assertion that humble CEOs will be more inclined to integrate the needs of all stakeholders, whereas less humble CEOs will be more focus on economic outcomes. Considering the adoption of socially responsible practices by firms has been found to be associated with their long-term sustainability (Lev, Petrovits, \& Radhakrishnan, 2010; Muller \& Kraussl, 2011; Wang \& Qian, 2011), it suggests executive humility can truly benefit organizations in the long run. These findings also contribute to the Upper Echelons literature since it is one of the first studies to examine the impact of a CEO's view of self on social outcomes.

This study do not provide clear conclusions in regard to the influence humble CEOs may have on a firm's level of R\&D spending. While the proposed individual humility indicators were not found to be significantly predictive of firm R\&D spending (at the exception of the CEO acknowledgement of the importance of other stakeholders in letters to shareholders), the overall humility index was. Considering the indicators included in the index conceptually capture different facets of humility, it could potentially mean that the sub-dimensions of humility are not individually predictive of firm R\&D spending, but that humility as an overall construct is. These results should be interpreted cautiously, and more research is needed to untangle the mixed findings.

Results did not confirm a relationship between CEO humility and firm performance. These findings add to the growing evidence that CEOs' individual 
characteristics best predict more proximal outcomes, such as firm strategies and culture, as opposed to more distal outcomes, such as firm performance (Finkelstein et al., 2009). While this study is based on a sample of companies representing a wide variety of industries, it would be interesting to examine if the firm performance hypothesis receives more support using a sample of firms operating in high-discretion industries - industries that are not highly regulated or constrained by their environments (Chatterjee \& Hambrick, 2007).

This study also shows preliminary evidence that the market appears to undervalue firms led by humble CEOs. Three out of the six partial humility indicators and the overall humility index point in that direction. Taken together, results from hypotheses three and four suggest firms led by humble CEOs do not perform better or worse, but the way they are valued by the market differs. Humble CEOs are less likely to be highly visible and hype their firm performance in the media, which potentially lead to lower market valuations.

My results also suggest that CEO humility predicts a different set of outcome variables than $\mathrm{CEO}$ narcissism. For example, CEO narcissism - measured using a narcissism index based on three validated unobtrusive indicators (i.e., CEO relative cash compensation, $\mathrm{CEO}$ relative non-cash compensation, and size of the $\mathrm{CEO}$ picture on annual reports) - was not significantly predictive of corporate social performance. Similarly, while the CEO humility index was found to be significantly negatively related to firm market valuation, $\mathrm{CEO}$ narcissism showed no relationship with firm market valuation. Together, these findings suggest CEO humility predicts a unique set of firmlevel outcomes and is not merely the low end of narcissism (i.e., antinarcissism). As such, 
the inclusion of humility in the executive leadership literature appears critical to enrich our understanding of the influence of CEO self-view on firms' behaviors.

Despite these contributions, this study has several limitations that should be mentioned. First, the unobtrusive indicators were not all successfully validated in the second study. Even though they appear conceptually related to humility (and its different dimensions), only two of the indicators were found to be significantly related to selfreported humility (i.e., CEO board membership on non-profits and CEO acknowledgement of the importance of other stakeholders to firm success). More validation, preferably using other-reported measures of humility, is needed. While some of the proposed indicators may not clearly capture CEO humility, the fact they have predictive value is, in itself, quite fascinating. For example, CEO breadth of education and CEO board membership on non-profits - two CEO characteristics which have never been explored in the Upper Echelons literature - were found to be positively significantly related to CSP.

The weak correlations found among the different humility indicators represent another limitation of this study. Considering the correlations among the humility indicators and Cronbach's alpha do not meet the suggested thresholds to form a new index (Nunnally, 1978), results from the aggregated humility index need to be interpreted cautiously. While the multi-faceted nature of the humility construct (i.e., formative construct) potentially explains some of the weak observed inter-correlations among the proposed humility indicators, it may also be that some of the indicators are not clearly capturing CEO humility. While I cannot ascertain that the index clearly captures CEO 
humility, its different components (i.e., attributes and behaviors) appear to be collectively predictive of different strategic outcomes (i.e., CSP, R\&D spending, and firm valuation).

Another important consideration is the possibility of reverse causality. For example, while we may expect humble CEOs to lead their organizations to greater social performance, humble CEOs may also be drawn to socially responsible organizations and/or socially responsible firms may be looking to hire CEOs with such profiles. As suggested by Hambrick (2007), the use of panel data and temporal lags as opposed to cross-sectional designs reduces the threat of reverse causality. For this study, dependent variables were measured each year starting on the second year of the CEO's tenure (i.e., one year lag). Alternatively, the CSR hypothesis was tested using a two-year lag (i.e., measuring CSR starting the third year of the CEO's tenure) and the results remained unchanged.

By integrating CEO humility to the literature on the strategic implications of CEOs' views of self, this study leads to a host of additional research avenues. First, it would be interesting to test similar hypotheses using a sample of firms in high-discretion industries, similar to what has been done in CEO narcissism research (Chatterjee \& Hambrick, 2007, 2011). CEOs' humble tendencies would likely have a greater impact in such high-discretion contexts. My results also point to the possibility that humble CEOs are more prevalent in some industries than others. Potentially, humble CEOs are drawn to and/or are more likely to get hired in some industries than others. For example, it would be interesting to test if humble CEOs are more prevalent in a people-focused industry such as healthcare. In addition, CEO humility might influence other proximal outcomes such as organizational ambidexterity - a firm's capacity to efficiently manage today's 
business demands, while also be adaptive to changes in its environment (Gibson \& Birkinshaw, 2004). Humble CEOs, who are characterized as having a learning orientation, may be particularly skilled at helping their organizations balance operation and exploitation. Lastly, it would be interesting to look at potential boundary conditions of the relationships between CEO humility and organizational-level outcomes. Are humble CEOs more effective in firms with participative cultures? Considering their learning orientation, are humble CEOs a better fit in highly dynamic environments? Will their cooperative approach to leadership and stakeholder orientation be considered too soft during difficult financial times? Considering humble CEOs are more likely to listen and include the input of other TMT members in their decisions, are the strategies of firms led by humble CEOs more of a reflection of their entire TMTs, rather than their CEOs? In sum, an abundant number of questions on the strategic implications of executive humility awaits management scholars. 


\section{List of References}

Agle, B. R., Mitchell, R. K., \& Sonnenfeld, J. A. (1999). Who Matters to CEOs? An Investigation of Stakeholder Attributes and Salience, Corporate Performance, and CEO Values. Academy of Management Journal, 42, 507-525.

Alexander, J. \& Wilson, M.S. (1997). Leading across cultures: Five vital capabilities. In F. Hesselbein, M. Goldsmith, \& R. Beckhard (Eds.), The Organization of the Future (pp. 287-294). San Francisco: Jossey-Bass.

Ames, D. R., Rose, P., \& Anderson, C. P. (2006). The NPI-16 as a short measure of narcissism. Journal of Research in Personality, 40, 440-450.

Ancona, D., Malone, T. W., Orlikowski, W. J., \& Senge, P. (2007). In praise of the incomplete leader. Harvard Business Review, 85, 92-100.

Arthaud-Day, M. L., Certo, S. T., Dalton, C. M., \& Dalton, D. R. (2006). A changing of the guard: Executive and director turnover following corporate financial restatements. Academy of Management Journal, 49, 1119-1136.

Ashton, M. C., \& Lee, K. (2001). A theoretical basis for the major dimensions of personality. European Journal of Personality, 15, 327-353.

Ashton, M. C., \& Lee, K. (2005). Honesty-Humility, the Big Five, and the Five-Factor Model. Journal of Personality, 73, 1321-1354.

Ashton, M. C., \& Lee, K. (2007). Empirical, theoretical, and practical advantages of the HEXACO model of personality structure. Personality and Social Psychology Review, 11, $150-166$.

Ashton, M. C., \& Lee, K. (2008). The prediction of Honesty-Humility-related criteria by the HEXACO and Five-Factor Models of personality. Journal of Research in Personality, 42, 1216-1228.

Avolio, B. J., Walumbwa, F. O., \& Weber, T. J. (2009). Leadership: Current theories, research, and future directions. Annual Review of Psychology, 60, 421-449.

Banse, R., Seise, J., \& Zerbes, N. (2001). Implicit attitudes towards homosexuality: Reliability, validity, and controllability of the IAT. Zeitschrift Für Experimentelle Psychologie, 48, 145-160.

Barbuto, J. E., \& Wheeler, D. W. (2006). Scale development and construct clarification of servant leadership. Group \& Organization Management, 31, 300-326. 
Barker, V. L., \& Mueller, G. C. (2002). CEO characteristics and firm R\&D spending. Management Science, 48, 782-801.

Baysinger, B. D. \& Hoskisson, R. E. (1989). Diversification strategy and R\&D intensity in large multiproduct firms. Academy of Management Journal, 32, 310-332.

Bebchuk, L. A., \& Fried, J. (2004). Pay without Performance. Cambridge, MA: Harvard University Press.

Becker, M. H. (1970). Factors affecting diffusion of innovations among health professionals. American Journal of Public Health and the Nations Health, 60, 294-304.

Berman, S. L., Wicks, A. C., Kotha, S., \& Jones, T. M. (1999). Does stakeholder orientation matter? The relationship between stakeholder management models and firm financial performance. Academy of Management Journal, 42, 488-506.

Bharadwaj, A. S., Bharadwaj, S. G., \& Konsynski, B. R. (1999). Information technology effects on firm performance as measured by Tobin's q. Management science, 45, 10081024.

Biernacki, P., \& Waldorf, D. (1981). Snowball sampling: Problems and techniques of chain referral sampling. Sociological methods \& research, 10, 141-163.

Blau, P. M. (1977). Inequality and heterogeneity. New York, NY: Free Press.

Bogart, L. M., Benotsch, E. G., \& Pavlovic, J. D. P. (2004). Feeling superior but threatened: The relation of narcissism to social comparison. Basic and Applied Social Psychology, 26, 35-44.

Browne, M. W., \& Cudeck, R. (1993). Alternative ways of assessing model fit. In K. A. Bollen \& J. S. Long (Eds.), Testing structural equation models (pp. 136-162). Newbury Park, CA: Sage.

Cain, M. D., \& Mckeon, S. B. (2012). Cleared for takeoff? CEO personal risk-taking and corporate policies. Working Paper, University of Notre Dame.

Carmeli, A. (2008). Top management team behavioral integration and the performance of service organizations. Group \& Organization Management, 33, 712-735.

Chang, C. H., Ferris, D. L., Johnson, R. E., Rosen, C. C., \& Tan, J. A. (2012). Core selfevaluations: A review and evaluation of the literature. Journal of Management, 38, 81128. 
Chatterjee, A., \& Hambrick, D. C. (2007). It's all about me: Narcissistic chief executive officers and their effects on company strategy and performance. Administrative Science Quarterly, 52, 351-386.

Chatterjee, A., \& Hambrick, D. C. (2011). Executive Personality, Capability Cues, and Risk Taking How Narcissistic CEOs React to Their Successes and Stumbles.

Administrative Science Quarterly, 56, 202-237.

Chin, M. K., Hambrick, D. C., \& Treviño, L. K. (2013). Political Ideologies of CEOs The Influence of Executives' Values on Corporate Social Responsibility. Administrative Science Quarterly, 58, 197-232.

Chung, K. H., \& Pruitt, S. W. (1994). A simple approximation of Tobin's q. Financial Management, 70-74.

Collins, J. (2001). Good to great: Why some companies make the leap... and others don't. New York, NY: HarperCollins.

Coombs, J. E., \& Gilley, K. M. (2005). Stakeholder management as a predictor of CEO compensation: main effects and interactions with financial performance. Strategic Management Journal, 26, 827-840.

Cropanzano, R., Bowen, D. E., \& Gilliland, S. W. (2007). The management of organizational justice. The Academy of Management Perspectives, 34-48.

Crossland, C., Zyung, K., Hiller, N. J., \& Hambrick, D. C. (2014). CEO career variety: Effects on firm-level strategic and social novelty. Academy of Management Journal, 58, 197-232.

Cycyota, C. S., \& Harrison, D. A. (2006). What (not) to expect when surveying executives a meta-analysis of top manager response rates and techniques over time. Organizational Research Methods, 9, 133-160.

Daily, C. M., Dalton, D. R., \& Cannella, A. A. (2003). Corporate governance: Decades of dialogue and data. Academy of Management Review, 28, 371-382.

Dalziel, T., Gentry, R. J., \& Bowerman, M. (2011). An Integrated Agency-Resource Dependence View of the Influence of Directors' Human and Relational Capital on Firms' R\&D Spending. Journal of Management Studies, 48, 1217-1242.

Daniels, M., Greguras, G. J., Bashshu, M. R., Oc, B. (2014, August). Cross-Cultural Comparison of Humility and Charisma Relationship with Status Incongruences as Moderators. Paper presented at the Academy of Management Conference, Philadelphia, PA 
Datta, D. K., \& Rajagopalan, N. (1998). Industry structure and CEO characteristics: An empirical study of succession events. Strategic Management Journal, 19, 833-852.

David, P., Hitt, M. A., \& Gimeno, J. (2001). The influence of activism by institutional investors on R\&D. Academy of Management Journal, 44, 144-157.

Davis, K. (1973), The Case For and Against Business Assumption of Social Responsibilities. Academy of Management Journal, 16, 312-322.

Deckop, J. R., Merriman, K. K., \& Gupta, S. (2006). The effects of CEO pay structure on corporate social performance. Journal of Management, 32, 329-342.

Diamantopoulos, A., \& Winklhofer, H. M. (2001). Index construction with formative indicators: an alternative to scale development. Journal of Marketing Research, 38, 269277.

Drucker, P. F. (1992). Managing for the future: The 1990s and beyond. New York, NY: Truman Talley/Dutton.

Eberhart, A. C., Maxwell, W. F., \& Siddique, A. R. (2004). An Examination of Long-Term Abnormal Stock Returns and Operating Performance Following R\&D Increases. The Journal of Finance, 59, 623-650.

Erickson, G., \& Jacobson, R. (1992). Gaining comparative advantage through discretionary expenditures: The returns to R\&D and advertising. Management Science, 38, 1264-1279.

Ettlie, J.E. (1998). R\&D and global manufacturing performance. Management Science, $44,1-11$.

Exline, J. J., \& Geyer, A. L. (2004). Perceptions of humility: A preliminary study. Self and Identity, 3, 95-114.

Finkelstein, S., Hambrick, D. C., \& Cannella, A. A. (2009). Strategic Leadership: Theory and research on executives, top management teams, and boards. New York, NY: Oxford University Press.

George, J. M., \& Brief, A. P. (1992). Feeling good-doing good: a conceptual analysis of the mood at work-organizational spontaneity relationship. Psychological Bulletin, 112, 310-329.

Giberson, T. R., Resick, C. J., Dickson, M. W., Mitchelson, J. K., Randall, K. R., \& Clark, M. A. (2009). Leadership and organizational culture: Linking CEO characteristics to cultural values. Journal of Business and Psychology, 24, 123-137. 
Gibson, C. B., \& Birkinshaw, J. (2004). The antecedents, consequences, and mediating role of organizational ambidexterity. Academy of management Journal, 47, 209-226.

Goodman, L. A. (1961). Snowball sampling. The Annals of Mathematical Statistics, 148170.

Gosling, S. D., Rentfrow, P. J., \& Swann Jr, W. B. (2003). A very brief measure of the Big-Five personality domains. Journal of Research in Personality, 37, 504-528.

Graves, S. B., \& Waddock, S. A. (1994). Institutional owners and corporate social performance. Academy of Management Journal, 37, 1034-1046.

Hackett, R. D., \& Wang, G. (2012). Virtues and leadership: An integrating conceptual framework founded in Aristotelian and Confucian perspectives on virtues. Management Decision, 50, 868-899.

Ham, C., Seybert, N., Wang, S., Lundblad, J. L., Sevilir, M., Tate, G., Williams, D., Zarowin, P., \& Zheng, Y. (2013). Narcissism is a Bad Sign: CEO Signature Size, Investment, and Performance. UNC Kenan-Flagler Research Paper, (2013-1).

Hambrick, D. C. (1994). Top management groups: A conceptual integration and reconsideration of the "team" label. In B. M. Staw \& L. L. Cummings (Eds.), Research in Organizational Behavior (pp.171-213). Greenwich, CT: JAI Press.

Hambrick, D. C. (2007). Upper echelons theory: An update. Academy of Management Review, 32, 334-343.

Hambrick, D. C., Cho, T. S., \& Chen, M. J. (1996). The influence of top management team heterogeneity on firms' competitive moves. Administrative Science Quarterly, 659684.

Hambrick, D. C., \& Mason, P. A. (1984). Upper echelons: The organization as a reflection of its top managers. Academy of Management Review, 9, 193-206.

Handelman, J. M., \& Arnold, S. J. (1999). The role of marketing actions with a social dimension: Appeals to the institutional environment. The Journal of Marketing, 33-48.

Hayward, M. L., \& Hambrick, D. C. (1997). Explaining the premiums paid for large acquisitions: Evidence of CEO hubris. Administrative Science Quarterly, 42, 103-127.

Henderson, A. D., Miller, D., \& Hambrick, D. C. (2006). How quickly do CEOs become obsolete? Industry dynamism, CEO tenure, and company performance. Strategic Management Journal, 27, 447-460. 
Hilbig, B. E., \& Zettler, I. (2009). Pillars of cooperation: Honesty-Humility, social value orientations, and economic behavior. Journal of Research in Personality, 43, 516-519.

Hilbig, B. E., Zettler, I., Leist, F., \& Heydasch, T. (2013). It takes two: HonestyHumility and Agreeableness differentially predict active versus reactive cooperation. Personality and Individual Differences, 54, 598-603.

Hill, C. W., \& Snell, S. A. (1989). Effects of ownership structure and control on corporate productivity. Academy of Management Journal, 32, 25-46.

Hiller, N. J., \& Beauchesne, M. M. (2014). Executive Leadership: CEOs, Top Management Teams, and Organizational-Level Outcomes, In David V. Day (Ed.), The Oxford Handbook of Leadership and Organizations (Chapter 30). New York, NY: Oxford University Press.

Hiller N.J., Beauchesne, M.M., Whitman, D. (2013, August). CEO personality, demography and firm-level outcomes: A meta-analysis of Upper Echelons Research. Paper presented at the Academy of Management Conference, Orlando, FL.

Hiller, N. J., \& Hambrick, D. C. (2005). Conceptualizing executive hubris: the role of (hyper-) core self-evaluations in strategic decision-making. Strategic Management Journal, 26, 297-319.

Hoskisson, R.E.,\& Hitt, M.A. (1988). Strategic control systems and relative R\&D investment in large multiproduct firms. Strategic Management Journal, 9, 605-621.

Hu, L., \& Bentler, P. M. (1998). Fit indices in covariance structure modeling: Sensitivity to underparameterized model misspecification. Psychological Methods, 3, 424-453.

Huselid, M. A., Jackson, S. E., \& Schuler, R. S. (1997). Technical and strategic human resources management effectiveness as determinants of firm performance. Academy of Management Journal, 40, 171-188.

Ireland, R. D., \& Hitt, M. A. (1999). Achieving and maintaining strategic competitiveness in the 21st century: The role of strategic leadership. Academy of Management Executive, 13, 43-57.

Jacobs, T. O., \& Jaques, E. (1987). Leadership in Complex Systems. New York, NY: Praeger.

Johnson, M. K., Rowatt, W. C., \& Petrini, L. (2011). A new trait on the market: HonestyHumility as a unique predictor of job performance ratings. Personality and Individual Differences, 50, 857-862. 
Judge, T. A., Locke, E. A., Durham, C. C., \& Kluger, A. N. (1998). Dispositional effects on job and life satisfaction: the role of core evaluations. Journal of Applied Psychology, 83, 17-34.

Kaiser, R. B., Hogan, R., \& Craig, S. B. (2008). Leadership and the fate of organizations. American Psychologist, 63, 96-110.

Katz, D., \& Kahn, R. L. (1978). The Social Psychology of Organizations (2nd ed.). New York, NY: Wiley.

Kimberly, J. R., \& Evanisko, M. J. (1981). Organizational innovation: The influence of individual, organizational, and contextual factors on hospital adoption of technological and administrative innovations. Academy of Management Journal, 24, 689-713.

Lee, K., \& Ashton, M. C. (2004). Psychometric properties of the HEXACO Personality Inventory. Multivariate Behavioral Research, 39, 329-358.

Lee, K., \& Ashton, M. C. (2006). Further assessment of the HEXACO Personality Inventory: two new facet scales and an observer report form. Psychological Assessment, $18,182-191$.

Lee, K., \& Ashton, M. C. (2012). Getting mad and getting even: Agreeableness and Honesty-Humility as predictors of revenge intentions. Personality and Individual Differences, 52, 596-600.

Lee, K., Ashton, M. C., Morrison, D. L., Cordery, J., \& Dunlop, P. D. (2008). Predicting integrity with the HEXACO personality model: Use of self-and observer reports. Journal of Occupational and Organizational Psychology, 81, 147-167.

Lev, B., Petrovits, C., \& Radhakrishnan, S. (2010). Is doing good good for you? How corporate charitable contributions enhance revenue growth. Strategic Management Journal, 31, 182-200.

Li, J., \& Tang, Y. I. (2010). CEO hubris and firm risk taking in China: The moderating role of managerial discretion. Academy of Management Journal, 53, 45-68.

Lin, C., Lin, P., Song, F. M., \& Li, C. (2011). Managerial incentives, CEO characteristics and corporate innovation in China's private sector. Journal of Comparative Economics, 39, 176-190.

Lindberg, E., \& Ross, S. (1981) Tobin's Q Ratio and Industrial Organization. Journal of Business, 51, 1-32.

Manner, M. H. (2010). The impact of CEO characteristics on corporate social performance. Journal of Business Ethics, 93, 53-72. 
Marcus, B., Lee, K., \& Ashton, M. C. (2007). Personality dimensions explaining relationships between integrity tests and counterproductive behavior: Big Five, or one in addition?. Personnel Psychology, 60, 1-34.

McWilliams, A., \& Siegel, D. (2000). Corporate social responsibility and financial performance: correlation or misspecification?. Strategic Management Journal, 21, 603609.

Michel, J. G., \& Hambrick, D. C. (1992). Diversification posture and top management team characteristics. Academy of Management Journal, 35, 9-37.

Miller, D., Kets de Vries, M. F. R., \& Toulouse, J. M. (1982). Top executives locus of control and its relationships to strategy making, structure, and environment. Academy of Management Journal, 25, 237-253.

Miller, D., \& Toulouse, J.M. (1986a). Chief executive personality and corporate strategy and structure in small firms. Management Science, 32, 1389-1409.

Miller, D., \& Toulouse, J.M. (1986b). Strategy, structure, CEO personality and performance in small firms. American Journal of Small Business, 10, 47-62.

Morbey, G. K. (1988). R\&D: Its relationship to company performance. Journal of Product Innovation Management, 5, 191-200.

Morris, J. A., Brotheridge, C. M., \& Urbanski, J. C. (2005). Bringing humility to leadership: Antecedents and consequences of leader humility. Human Relations, 58, 1323-1350.

Muller, A., \& Kräussl, R. (2011). Doing good deeds in times of need: A strategic perspective on corporate disaster donations. Strategic Management Journal, 32, 911-929.

Nadkarni, S., \& Herrmann, P. O. L. (2010). CEO personality, strategic flexibility, and firm performance: the case of the Indian business process outsourcing industry. Academy of Management Journal, 53, 1050-1073.

Nederhof, A. J. (1985). Methods of coping with social desirability bias: A review. European Journal of Social Psychology, 15, 263-280.

Nembhard, I. M., \& Edmondson, A. C. (2006). Making it safe: The effects of leader inclusiveness and professional status on psychological safety and improvement efforts in health care teams. Journal of Organizational Behavior, 27, 941-966. 
Nielsen, R., Marrone, J. A., \& Slay, H. S. (2010). A new look at humility: Exploring the humility concept and its role in socialized charismatic leadership. Journal of Leadership \& Organizational Studies, 17, 33-43.

Nunnally, J. (1978). Psychometric methods. New York: McGraw-Hill.

Olsen, K., Dworkis, K. K., \& Young, S. M. (2013). CEO Narcissism and Accounting: a picture of profits. Journal of Management Accounting Research, 1-27.

Organ, D. W., \& Ryan, K. (1995). A meta-analytic review of attitudinal and dispositional predictors of organizational citizenship behavior. Personnel psychology, 48, 775-802.

Ou, A. Y. (2011). CEO humility and its relationship with middle manager behaviors and performance: Examining the CEO-middle manager interface (Doctoral dissertation). Arizona State University, Phoenix, Arizona.

Ou, A.Y., Su, Q., Chiu, C.Y., Owens, B., (2014, August). Cross-Cultural Comparison of Humility and Charisma Relationship with Status Incongruences as Moderators. Paper presented at the Academy of Management Conference, Philadelphia, PA.

Ou, A. Y., Tsui, A. S., Kinicki, A. J., Waldman, D. A., Xiao, Z., \& Song, L. J. (2014). Humble chief executive officers' connections to top management team integration and middle managers' responses. Administrative Science Quarterly, 0001839213520131.

Owens, B. P. (2009). Humility in Organizational Leadership (Doctoral dissertation). Oregon State University, Corvallis, Oregon.

Owens, B. P., \& Hekman, D. R. (2012). Enacting humble leadership: An inductive examination of humble leader behaviors, outcomes, and contingencies. Academy of Management Journal, 55, 787-818.

Owens, B. P., Johnson, M. D., \& Mitchell, T. R. (2013). Expressed humility in organizations: Implications for performance, teams, and leadership. Organization Science, 24, 1517-1538.

Owens, B. P., Rowatt, W. C., \& Wilkins, A. L. (2011). Exploring the relevance and implications of humility in organizations. In K. S. Cameron and G. M. Spreitzer (Eds.), Handbook of Positive Organizational Scholarship. Oxford: Oxford University Press.

Park, N., \& Peterson, C. (2003). Virtues and organizations. Positive Organizational Scholarship: Foundations of a New Discipline, 33-47.

Pennebaker, J. W., \& King, L. A. (1999). Linguistic styles: language use as an individual difference. Journal of Personality and Social Psychology, 77, 1296-1312. 
Perugini, M., Gallucci, M., Presaghi, F., \& Ercolani, A. P. (2003). The personal norm of reciprocity. European Journal of Personality, 17, 251-283.

Peterson, C.,\& Seligman, M. E. P. (2004). Character strengths and virtues: A handbook and classification. New York: Oxford University Press/Washington, DC: American Psychological Association.

Peterson, R. S., Smith, D. B., Martorana, P. V., \& Owens, P. D. (2003). The impact of chief executive officer personality on top management team dynamics: One mechanism by which leadership affects organizational performance. Journal of Applied Psychology, $88,795-808$.

Pitcher, P., Chreim, S.,\& Kisfalvi, V. (2000). CEO Succession Research: Methodological Bridges Over Troubled Waters. Strategic Management Journal, 21, 625-648.

Podsakoff, P. M., MacKenzie, S. B., \& Hui, C. (1993). Organizational citizenship behaviors and managerial evaluations of employee performance: A review and suggestions for future research. Research in Personnel and Human Resources Management, 11, 1-40.

Resick, C. J., Whitman, D. S., Weingarden, S. M., \& Hiller, N. J. (2009). The bright-side and the dark-side of CEO personality: Examining core self-evaluations, narcissism, transformational leadership, and strategic influence. Journal of Applied Psychology, 94, 1365-1381.

Rogers, E. M., \& Shoemaker, F. F. (1971). Communication of innovations. New York, NY: The Free Press.

Roll, L. (1986). The hubris hypothesis of corporate takeovers. Journal of Business, 59, 197-218.

Rosenthal, S. A., \& Pittinsky, T. L. (2006). Narcissistic leadership. The Leadership Quarterly, 17, 617-633.

Rotter, J. B. (1966). Generalized expectancies for internal versus external control of reinforcement. Psychological Monographs, 80, 1-28.

Rowatt, W. C., Powers, C., Targhetta, V., Comer, J., Kennedy, S., \& Labouff, J. (2006). Development and initial validation of an implicit measure of humility relative to arrogance. The Journal of Positive Psychology, 1, 198-211.

Shepherd, S., \& Belicki, K. (2008). Trait forgiveness and traitedness within the HEXACO model of personality. Personality and Individual Differences, 45, 389-394. 
Sheppard, K., \& Boon, S. D. (2012). Predicting appraisals of romantic revenge: The roles of Honesty-Humility, Agreeableness, and vengefulness. Personality and Individual Differences, 52, 128-132.

Scherer, F.M. (1984). Innovation and Growth: Schumpetarian Perspectives. Cambridge, MA: MIT Press.

Sharma, S., \& Vredenburg, H. (1998). Proactive corporate environmental strategy and the development of competitively valuable organizational capabilities. Strategic Management Journal, 19, 729-753.

Sidek, S., \& Zainol, F. A. (2011). Psychological traits and business performance of entrepreneurs in small construction industry in Malaysia. International Business and Management, 2, 170-185.

Simsek, Z., Heavey, C., \& Veiga, J. F. (2010). The impact of CEO core self-evaluation on the firm's entrepreneurial orientation. Strategic Management Journal, 31, 110-119.

Slater, D. J., \& Dixon-Fowler, H. R. (2009). CEO international assignment experience and corporate social performance. Journal of Business Ethics, 89, 473-489.

Sun, S. (2014, August). Cross-level interactive effects between proactive personality and humble leadership on work-family conflict: Mediating role of emotional exhaustion. Paper presented at the Academy of Management Conference, Philadelphia, PA.

Tang, Y., Li, J., \& Yang, H. (2012). What I see, what I do: How executive hubris affects firm innovation. Journal of Management, 0149206312441211.

Tang, Y., Qian, C., Chen, G., \& Shen, R. (2014). How CEO hubris affects corporate social responsibility. Strategic Management Journal, DOI: 10.1002/smj.2286.

Tangney, J. P. (2000). Humility: Theoretical perspectives, empirical findings and directions for future research. Journal of Social and Clinical Psychology, 19, 70-82.

Tangney, J. P. (2002). Humility. In C. R. Snyder \& S. J. Lopez (Eds.), Handbook of Positive Psychology (pp. 411-419). London: Oxford University Press.

Templeton, J. M. (1997). Worldwide Laws of Life. 200 Eternal Spiritual Principles.

Thomas, A. S., Litschert, R. J., \& Ramaswamy, K. (1991). The performance impact of strategy-manager coalignment: An empirical examination. Strategic Management Journal, 12, 509-522.

Tjan, A.K. (2012, July19). How leaders become self-aware. Retrieved from http://blogs.hbr.org/ 
Tosi, H. L., \& Gomez-Mejia, L. R. (1989). The decoupling of CEO pay and performance: An agency theory perspective. Administrative Science Quarterly, 34, 169-189.

Turban, D. B., \& Greening, D.W. (1996). Corporate social performance and organizational attractiveness to prospective employees. Academy of Management Journal, 40, 658-672.

Valentine, S., \& Fleischman, G. (2008). Ethics programs, perceived corporate social responsibility and job satisfaction. Journal of Business Ethics, 77, 159-172.

Van de Ven, A. H., Hudson, R., \& Schroeder, D. M. (1984). Designing new business startups: Entrepreneurial, organizational, and ecological considerations. Journal of Management, 10, 87-108.

Vera, D., \& Rodriguez-Lopez, A. (2004). Strategic virtues: Humility as a source of competitive advantage. Organizational Dynamics, 33, 393-408.

Waddock, S. A., \& Graves, S. B. (1997), The Corporate Social Performance - Financial Performance Link. Strategic Management Journal, 18, 303-319.

Wang, H., \& Qian, C. (2011). Corporate philanthropy and corporate financial performance: The roles of stakeholder response and political access. Academy of Management Journal, 54, 1159-1181.

Webb, E. J., Campbell, D. T., Schwartz, R. D., \&Sechrest, L. (1966). Unobtrusive measures: Non-reactive research in the social sciences. Chicago: Rand McNally.

Weick, K. E. (2001). Leadership as the legitimization of doubt. In W. Bennis, G. M. Spreitzer, \& T. G. Cummings (Eds.). The future of leadership: Today's top leadership thinkers speak to tomorrow's leaders (pp.91-102). San Francisco: Jossey-Bass.

Wiersema, M. F., \& Bantel, K. A. (1992). Top management team demography and corporate strategic change. Academy of Management Journal, 35, 91-121.

Weiss, H. M., \& Knight, P. A. (1980). The utility of humility: Self-esteem, information search, and problem-solving efficiency. Organizational Behavior and Human Performance, 25, 216-223.

Whitener, E. M., Brodt, S. E., Korsgaard, M. A., \& Werner, J. M. (1998). Managers as initiators of trust: An exchange relationship framework for understanding managerial trustworthy behavior. Academy of Management Review, 23, 513-530.

Wood, D. J. (1991), Corporate Social Performance Revisited, Academy of Management Review, 16, 691-718. 
Zald, M. N. (1969). The power and functions of boards of directors: A theoretical synthesis. American Journal of Sociology, 97-111.

Zhang, Z., Peterson, S. J., \& Reina, C. S. (2013). CEO narcissism and firm performance: The moderating roles of core self- evaluations and organizational identification. Working paper. 
Appendices 
Appendix A: Factor Loadings and Cronbach's Alphas for Each Dimension of Humility

\begin{tabular}{|l|c|c|}
\hline \multicolumn{1}{|c|}{ Items } & $\begin{array}{c}\text { Cronbach's } \\
\text { Alpha }\end{array}$ & $\begin{array}{c}\text { Self- } \\
\text { Reported } \\
\text { Loading }\end{array}$ \\
\hline Self-Awareness & .583 & .67 \\
I1. I actively seek feedback, even if it is critical. & .78 \\
I2. I acknowledge when others have more knowledge and skills & & \\
than me. & .693 & .78 \\
I3. I admit when I don't know how to do something. & \\
Appreciation of Others & .843 & .63 \\
I4. I show appreciation for the contributions of others. & \\
I5. I take notice of the strengths of others. & & .92 \\
I6. I often compliment others on their strengths. & \\
Teachability & .864 & .86 \\
I7. I am willing to learn from others. & & .90 \\
I8.I am open to the ideas of others. & & .89 \\
I9. I am open to the advice of others. & & \\
Low Self-Focus & & \\
I10. I do not like to draw attention to myself. & & \\
I11. I keep a low profile. & & \\
I12. I am not interested in obtaining fame for myself. & & \\
\hline
\end{tabular}




\section{FIU canteres Leadership}

FLORIDA INTERNATIONAL UNIVERSITY

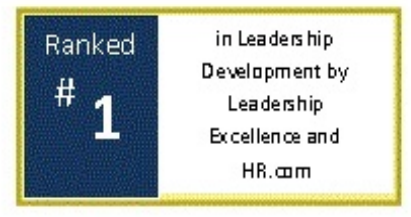

Dear (name of participant),

The Center for Leadership at Florida International University (FIU) is engaged in a research study to understand how different CEOs operate and how personality impacts strategy. This survey research is being conducted by Dr. Nathan J. Hiller and $\mathrm{PhD}$ candidate Marie-Michèle Beauchesne.

If you choose to participate in this study, you will be asked to complete a brief online survey. The survey includes questions about yourself, your top management team and your organization. It will take no more than 15 minutes of your time to complete. This survey is confidential and information about you or your participation will never be revealed; only aggregate scores will be used in reporting findings. We will provide participants with a report of our main findings following the completion of this research project. In addition, we will award each participant in the survey a 2014 FIU Partner-in-Research Seal, which you may display on your company website, e-mails, or stationery. This survey is computer-based and may be accessed via the link at the end of this email.

If you have any questions regarding this survey, please contact Marie-Michele Beauchesne at (914) 844-8213 or mbeauche@fiu.edu. To access the survey, please click on the link below.

Thank you in advance for your participation in this research study!

Marie-Michele Beauchesne \& Nathan J. Hiller 
Appendix C: Survey

Q1. Is your organization a:

For-Profit

O Not-For-Profit

O Government

Q2. What is the primary industry of your organization? (If unsure, choose the "best fit")

O Basic Materials

Consumer Goods

Consumer Services

O Financials

O Health Care

Industrials

Oil \& Gas

Technology

O Telecommunications

Otilities

O Other

Q3. What were the annual revenues of your organization in 2013 ?

O Less than $\$ 1.0 \mathrm{M}$

O $\$ 1.0 \mathrm{M}-\$ 4.9 \mathrm{M}$

O $\$ 5.0 \mathrm{M}-\$ 9.9 \mathrm{M}$

O $\$ 10.0 \mathrm{M}-\$ 24.9 \mathrm{M}$

O $\$ 25.0 \mathrm{M}-\$ 49.9 \mathrm{M}$

O $\$ 50.0 \mathrm{M}-\$ 99.9 \mathrm{M}$

O $\$ 100.0 \mathrm{M}-\$ 499.9 \mathrm{M}$

$\mathrm{O}>\$ 500.0 \mathrm{M}$

Q4. How many employees are currently employed by your organization?

O $1-9$

O $10-19$

O $20-49$

O $50-99$

O $100-499$

O $500-999$

O 1000-4999

O $>5000$ 
Q5. Below are several statements about yourself with which you may agree or disagree. Using a 5-point scale, indicate your agreement or disagreement with each item.

\begin{tabular}{|c|c|c|c|c|c|}
\hline & Strongly Agree & Agree & $\begin{array}{l}\text { Neither Agree } \\
\text { nor Disagree }\end{array}$ & Disagree & $\begin{array}{l}\text { Strongly } \\
\text { Disagree }\end{array}$ \\
\hline $\begin{array}{l}\text { I actively seek } \\
\text { feedback, even } \\
\text { if it is critical. }\end{array}$ & $\mathrm{O}$ & $\mathrm{O}$ & O & 0 & $\mathrm{O}$ \\
\hline $\begin{array}{l}\text { I acknowledge } \\
\text { when others } \\
\text { have more } \\
\text { knowledge and } \\
\text { skills than me. }\end{array}$ & 0 & $\mathrm{O}$ & O & $\mathrm{O}$ & $\mathrm{O}$ \\
\hline $\begin{array}{l}\text { I admit when I } \\
\text { don't know how } \\
\text { to do } \\
\text { something. }\end{array}$ & O & $\mathrm{O}$ & $\mathrm{O}$ & $\mathrm{O}$ & $\mathrm{O}$ \\
\hline $\begin{array}{l}\text { I show } \\
\text { appreciation for } \\
\text { the } \\
\text { contributions of } \\
\text { others. }\end{array}$ & O & $\mathrm{O}$ & O & $\mathrm{O}$ & $\mathrm{O}$ \\
\hline $\begin{array}{l}\text { I take notice of } \\
\text { the strengths of } \\
\text { others. }\end{array}$ & $\mathrm{O}$ & $\mathrm{O}$ & $\mathrm{O}$ & $\mathrm{O}$ & $\mathrm{O}$ \\
\hline $\begin{array}{c}\text { I often } \\
\text { compliment } \\
\text { others on their } \\
\text { strengths. }\end{array}$ & $\mathrm{O}$ & $\mathrm{O}$ & $\mathrm{O}$ & $\mathrm{O}$ & $\mathrm{O}$ \\
\hline $\begin{array}{l}\text { I am willing to } \\
\text { learn from } \\
\text { others. }\end{array}$ & $\mathrm{O}$ & $\mathrm{O}$ & $\mathrm{O}$ & $\mathrm{O}$ & $\mathrm{O}$ \\
\hline $\begin{array}{l}\text { I am open to the } \\
\text { ideas of others. }\end{array}$ & $\mathrm{O}$ & $\mathrm{O}$ & $\mathrm{O}$ & $\mathrm{O}$ & $\mathrm{O}$ \\
\hline $\begin{array}{l}\text { I am open to the } \\
\text { advice of } \\
\text { others. }\end{array}$ & $\mathrm{O}$ & $\mathrm{O}$ & $\mathrm{O}$ & $\mathrm{O}$ & O \\
\hline $\begin{array}{l}\text { I do not like to } \\
\text { draw attention } \\
\text { to myself. }\end{array}$ & $\mathrm{O}$ & $\mathrm{O}$ & $\mathrm{O}$ & $\mathrm{O}$ & $\mathrm{O}$ \\
\hline $\begin{array}{c}\text { I keep a low } \\
\text { profile. }\end{array}$ & $\mathrm{O}$ & $\mathrm{O}$ & 0 & 0 & $\mathrm{O}$ \\
\hline $\begin{array}{c}\text { I am not } \\
\text { interested in } \\
\text { obtaining fame } \\
\text { for myself. }\end{array}$ & $\mathrm{O}$ & $\mathrm{O}$ & $\mathrm{O}$ & $\mathrm{O}$ & $\mathrm{O}$ \\
\hline
\end{tabular}


Q6. I see myself as:

\begin{tabular}{|c|c|c|c|c|c|}
\hline & Strongly Agree & Agree & $\begin{array}{l}\text { Neither Agree } \\
\text { nor Disagree }\end{array}$ & Disagree & $\begin{array}{l}\text { Strongly } \\
\text { Disagree }\end{array}$ \\
\hline $\begin{array}{l}\text { Extroverted, } \\
\text { enthusiastic. }\end{array}$ & O & O & O & O & O \\
\hline $\begin{array}{l}\text { Open to new } \\
\text { experiences, } \\
\text { complex. }\end{array}$ & O & O & $\mathrm{O}$ & O & $\mathrm{O}$ \\
\hline $\begin{array}{l}\text { Calm, } \\
\text { emotionally } \\
\text { stable. }\end{array}$ & O & O & O & O & $\mathrm{O}$ \\
\hline $\begin{array}{c}\text { Conventional, } \\
\text { uncreative. }\end{array}$ & O & O & O & O & O \\
\hline Reserved, quiet. & $\mathrm{O}$ & $\mathrm{O}$ & 0 & $\mathrm{O}$ & 0 \\
\hline $\begin{array}{l}\text { Anxious, easily } \\
\text { upset. }\end{array}$ & 0 & O & 0 & O & O \\
\hline
\end{tabular}

Q7. Read each pair of statements below and check the statement that comes closest to describing your feelings and beliefs about yourself. You may feel that neither statement describes you well, but pick the one that comes closest. Please complete all pairs.

I really like to be the center of attention

It makes me uncomfortable to be the center of attention

I I am no better or no worse than most people

I think I am a special person

Everybody likes to hear my stories

Sometimes I tell good stories

I usually get the respect that I deserve

I insist upon getting the respect that is due to me

I don't mind following orders

I like having authority over people

I am going to be a great person

I hope I am going to be successful 
O People sometimes believe what I tell them

O I can make anybody believe anything I want them to

I expect a great deal from other people

O I like to do things for other people

I like to be the center of attention

I prefer to blend in with the crowd

I am much like everybody else

O I am an extraordinary person

I always know what I am doing

O Sometimes I am not sure of what I am doing

I don't like it when I find myself manipulating people

O I find it easy to manipulate people

Being an authority doesn't mean that much to me

O People always seem to recognize my authority

I know that I am good because everybody keeps telling me so

When people compliment me I sometimes get embarrassed

O I try not to be a show off

I am apt to show off if I get the chance

I am more capable than other people

There is a lot that I can learn from other people 
Q8. What is the highest level of education you have completed?

O Below high school

High school

Some college

O Bachelor's degree

Master's degree

Doctorate

Q9. In how many unique fields have you studied (e.g., an undergraduate degree in engineering followed by an MBA would be " 2 ", whereas an undergraduate degree in business administration followed by an MBA would be "1")?

○ 1

O 2

O 3

○ 4 or more

Q10. Including your current company, how many organizations have you worked for since you were 21 years old?

O 1

O 2

○ 3

O 4

O 5

○ 6

○ 7 or more

Q11. Throughout your career, the positions you have held fall into which of these functional tracks? Check all that apply.

$\square$ Production/Operations

- R\&D/Engineering

- Accounting/Finance

Management/Administration

- Marketing/Sales

- Human Resources

口 Law

$\square$ Other 
Q12. Throughout your career, in which of these industries have you worked in? Check all that apply.

口 Basic Materials

- Consumer Goods

$\square$ Consumer Services

- Financials

Health Care

Industrials

O Oil \& Gas

Technology

- Telecommunications

U Utilities

$\square$ Other

Q13. Do you hold both the titles of CEO and Chair of the board in your current organization?

O Yes

O No

Q14. Are you a founder of the company?

O Yes

O No

Q15. Prior to becoming CEO, you were:

Working at the same organization in a different position

O Working at a different organization

Q16. How long have you been CEO of your current company?

O Less than a year

O 1-2

O $2-5$

O $5-8$

O 8 or more

Q17. How would you describe the composition of your top management team (TMT) in regards to their educational backgrounds?

Sliding Scale (1 to 4$)$

Q18. How would you describe the composition of your top management team (TMT) in regards to their functional experiences (e.g., Finance, Operations, Accounting, HR)? Sliding Scale (1 to 4$)$ 
Q19. What was the ratio between your total compensation (salary, bonuses, equity, etc.) and the total compensation of the second-highest-paid executive in your firm last year?

Less than 1 (i.e., less than the total compensation of the second-highest-paid executive)

O 1 (i.e., approximately the same total compensation)

O 1.25 (i.e., approximately $25 \%$ more)

O 1.5 (i.e., approximately $50 \%$ more)

O 1.75 (i.e., approximately $75 \%$ more)

O 2 (i.e., approximately 2 times more)

O 3-5 (i.e., approximately 3 to 5 times more)

5-10 (i.e., approximately 5 to 10 times more)

O >10 (i.e., more than 10 times)

Q20. Describe the importance of these different factors on your organization's success

\begin{tabular}{|c|c|c|c|c|c|}
\hline & Unimportant & $\begin{array}{c}\text { Of Little } \\
\text { Importance }\end{array}$ & $\begin{array}{c}\text { Moderately } \\
\text { Important }\end{array}$ & Important & Very Important \\
\hline $\begin{array}{c}\text { Firm's internal } \\
\text { capabilities } \\
\text { (e.g., } \\
\text { knowledge, } \\
\text { patents, } \\
\text { technologies) }\end{array}$ & 0 & 0 & 0 & 0 & 0 \\
\hline $\begin{array}{c}\text { Leadership of } \\
\text { top } \\
\text { management } \\
\text { team }\end{array}$ & 0 & 0 & 0 & 0 & 0 \\
\hline $\begin{array}{c}\text { Macro- } \\
\text { economic } \\
\text { conditions (e.g., } \\
\text { economy, } \\
\text { employment } \\
\text { levels, etc.) }\end{array}$ & 0 & 0 & 0 & 0 & 0 \\
\hline $\begin{array}{c}\text { Industry's } \\
\text { forces (e.g., } \\
\text { rules and } \\
\text { regulations, } \\
\text { level of } \\
\text { competition, } \\
\text { etc.) }\end{array}$ & 0 & 0 & 0 & 0 & 0 \\
\hline $\begin{array}{c}\text { Performance } \\
\text { level of } \\
\text { employees }\end{array}$ & 0 & 0 & 0 & 0 & 0 \\
\hline $\begin{array}{c}\text { Insights from } \\
\text { board of } \\
\text { directors }\end{array}$ & 0 & 0 & & & \\
\hline
\end{tabular}


Q21. Are you currently serving as a board member or involved in a non-profit organization?

$O$ Yes

O No

Q22. Your name (Last, first):
Q23. Age:
O $<30$
O $30-34$
O $35-39$
O $40-44$
O $45-49$
O $50-54$
O $55-59$
O $60-64$
O $>65$

\section{Q24. Organization Name:}

Q25. Your email:

Q26. Would you like to receive a 2014 FIU Partner-in-Research Seal for your participation in this study? You may display the seal on your company website, e-mails, or stationery.

O Yes, please email me a 2014 FIU Partner-in-Research Seal

O No 
Appendix D: IRB Approval

FLORIDA

INTERNATIONAL

Office of Research Integrity

UNIVERSITY

\section{MEMORANDUM}

To: Dr. Nathan Hiller

CC: $\quad$ File

From: Donna J. Simonovitch, Coordinator, Research Integrity

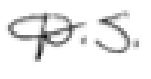

Date: $\quad$ April 22, 2014

Protocol Title: CEO Humility: Development of an Unobstrusive Measure and Strategic Implications

The Florida Intemational University Office of Research Integrity has reviewed your research study for the use of human subjects via the Exempt Review process.

IRB Protocol Exemption \#: $\quad$ IRB-14-0070 IRB Exemption Date: $\quad$ 04/22/14

TOPAZ Reference \#: $\quad 102261$

As a requirement of IRB Exemption you are required to:

1) Submit an Event Form and provide immediate notification of:

- Any additions or changes in the procedures involving human subjects.

- Every serious or unusual or unanticipated adverse event as well as problems with the rights or welfare of the human subjects.

2) Submit a Project Completion Report Form when the study is finished or discontinued.

\section{Special N/A \\ Conditions:}

For further information, you may visit the IRB website at http://research.fiu.edu/irb. 
VITA

\section{MARIE-MICHELE BEAUCHESNE}

Born, Quebec City, Canada

2003-2006

Bachelor of Business Administration

Laval University

Quebec City, Canada

GPA 3.92 out of 4

2008-2008

Master of Business Administration

University of Miami

Coral Gables, Florida

GPA 3.92 out of 4

2010-2014

Ph.D. in Business Administration

Florida International University

Miami, Florida

GPA 3.93 out of 4

2014-present

Assistant Professor, Management

Barry University

Miami Shores, Florida

\section{PUBLICATIONS AND PRESENTATIONS}

Hiller, Nathan J., \& Beauchesne, Marie-Michele (2014). Executive leadership: CEOs, top management teams and organizational-level outcomes, In David V. Day (Ed.), The Oxford Handbook of Leadership and Organizations. New York, NY: Oxford University Press.

Beauchesne, M.M., Hiller, N.J. (2014, August). CEO humility: development of an unobtrusive measure and strategic implications. Paper presented at the Academy of Management Conference, Philadelphia, PA.

Sanchez, J.I., Dai G., Beauchesne, M.M. (2014, May). Multi-rater consensus in competency models: (not always) separating the person from the job. Paper presented at the Society for Industrial and Organizational Psychology Conference, Honolulu, HI.

Hiller N.J., Beauchesne, M.M., Whitman, D. (2013, August). CEO personality, demography and firm-level outcomes: A meta-analysis of Upper Echelons Research. Paper presented at the Academy of Management Conference, Orlando, FL. 
Hiller, N.J., Beauchesne, M.M., Whitman, D. (2012, April). Level matters: The relationship between executive personality and firm-level outcomes. Paper presented at the Society for Industrial and Organizational Psychology Conference, San Diego, CA. 